This is the peer reviewed version of the following article: Chem. Eur. J. 2012, 18, 4844, which has been published in final form at http://onlinelibrary.wiley.com/doi/10.1002/chem.201103971/abstract. This article may be used for non-commercial purposes in accordance With Wiley-VCH Terms and Conditions for self-archiving

\title{
Catalytic Enantiospecific [3+2] Annulation of Aminocyclopropanes with Ketones
}

\author{
Fides Benfatti, Florian de Nanteuil and Jérôme Waser*[a]
}

Dedication ((optional))

The exploitation of strain release in small rings as a driving force to trigger synthetic transformations has received increased attention over the last decade. In this context, cyclopropanes have been predominantly investigated, due to the abundance of efficient methods for their preparation, combined with their exceptional reactivity. A strategy to further enhance the inherent strain energy of cyclopropanes consists in the introduction of vicinal Donor and Acceptor groups (D and A, Scheme 1), able to stabilize the incipient positive and negative charges derived from the cleavage of the activated $\sigma$ bond. The so-called D-A cyclopropanes can therefore be considered synthetic equivalent to 1,3 zwitterionic synthons. ${ }^{[1]}$ As such, they have been extensively used in [3+2] annulations. ${ }^{[2]}$ These reactions allow the efficient assembly of a variety of 5-membered hetero- and carbocycles. In particular, the $[3+2]$ reaction with carbonyl compounds ${ }^{[3,4]}$ represents a valuable tool for the synthesis of tetrahydrofurans (THFs). ${ }^{[5]}$

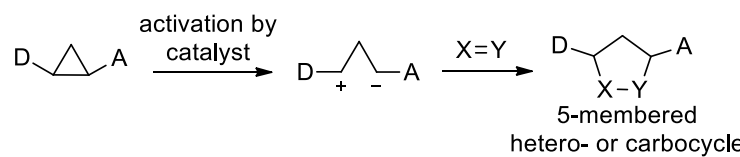

Scheme 1. Donor-Acceptor cyclopropanes as 1,3 zwitterionic synthons. $\mathrm{D}=$ donor. $\mathrm{A}=$ acceptor. $\mathrm{X}=\mathrm{Y}=$ generic double bond.

The annulation of D-A cyclopropanes with aldehydes is well established, and efficient catalytic as well as enantioselective protocols have been reported. ${ }^{[3 f, h-n]}$ On the contrary, only a few catalytic methods have been described for the annulation involving the less reactive ketones as reaction partners. ${ }^{[4]}$ Furthermore, the scarcity of highly diastereoselective protocols

[a] Dr. F. Benfatti, F. de Nanteuil, Prof. Dr. J. Waser Laboratory of Catalysis and Organic Synthesis

Ecole Polytechnique Fédérale de Lausanne, EPFL SB ISIC LCSO BCH 4306, 1015 Lausanne (Switzerland)

Fax: (+41) 21-693-9700

E-mail: jerome.waser@epfl.ch

((Note: If Supporting Information is submitted, please include the following line:))

Supporting information for this article is available on the WWW under http://www.chemeurj.org/ or from the author. indicates an intrinsic difficulty to achieve face discrimination in the addition of D-A cyclopropanes onto non-symmetrical ketones. ${ }^{[6]}$

In this context, and with our recent advancements involving cyclization and annulation reactions of D-A cyclopropanes in hand, ${ }^{[7]}$ we sought out to develop a catalytic and stereoselective protocol for the [3+2] annulation between D-A aminocyclopropanes and ketones. There are only few reports of annulation and cyclization reactions of D-A aminocyclopropanes, ${ }^{[8]}$ despite their high synthetic potential for the preparation of N-containing hetero- and carbocycles. Implementing the [3+2] annulation of D-A cyclopropanes with ketones would indeed allow an expedient access to a variety of 2aminotetrahydrofurans bearing a rare quaternary carbon in position 5 (Scheme 2). Furthermore, the 2-aminotetrahydrofuran scaffold can be rightly considered as a "privileged structure", due to its occurrence in nucleosides and in nucleosides-derived synthetic drugs. ${ }^{[9]}$ It is noteworthy that current methods mainly yield analogues bearing a tertiary centre at C5 (Scheme 2), with little deviation from the natural molecules. ${ }^{[10]}$ The methodology described herein, however, allows to access the less explored chemical space populated by structures bearing a quaternary C5. Herein, we report the first catalytic [3+2] annulation of D-A aminocyclopropanes with ketones, allowing the preparation of rare C5-disubstituted aminotetrahydrofurans. In contrast with our previous work with aldehydes using an iron catalyst which proceeded with racemization, ${ }^{[7 f]}$ the tin-catalyzed annulation of ketones is enantiospecific, giving access to enantioenriched aminotetrahydrofurans.

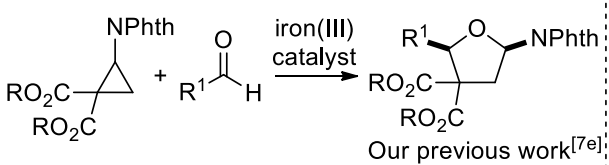

2-aminoTHFs<smiles>[R]C1([R])CCC(N2CCC2)O1</smiles>
$\mathbf{R}^{1}$ or $\mathbf{R}^{2}=\mathbf{H}$ Nucleosides

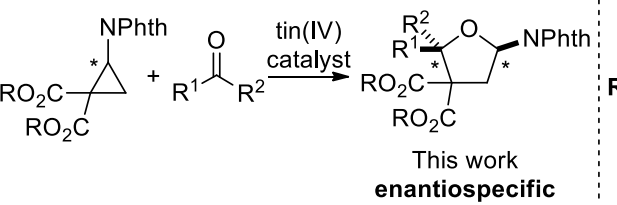
core structure $\mathbf{R}^{1}, \mathbf{R}^{2}=$ alkyl, aryl Under-explored chemical space

Scheme 2. [3+2] annulation of D-A aminocyclopropanes with carbonyl compounds. Phth $=$ phthaloyl. 
We commenced our investigation by screening Lewis acids for the model reaction of phthaloyl cyclopropane 1a with acetophenone (2a). At first, we tested iron (III) chloride on alumina, which successfully promoted the [3+2] annulation with aldehydes (Table 1, entry 1). ${ }^{[7]}$ Unfortunately, a poor yield was obtained, due to extensive degradation of the cyclopropane partner in the presence of the catalyst. We then examined tin(IV) chloride, which we had employed to promote the [3+2] annulation of phthaloyl cyclopropane with silyl enol ethers (Table 1, entry 2). ${ }^{[7 \mathrm{e}]}$ At $-78{ }^{\circ} \mathrm{C}$, complete conversion was observed after 90 minutes, and the desired aminotetrahydrofuran 3aa was formed quantitatively, as a single diastereoisomer. The relative configuration of 3aa was unambiguously assigned to be 2,5-cis on the basis of x-ray diffraction analysis. ${ }^{[11]}$ Other metal chloride salts failed to catalyse the process, with the surprising exception of gold(III) chloride, which gave 3aa in modest yield (entry 3). Due to decomposition of $\mathbf{1 a}$, the screening of metal triflates (entries 4-8) did not lead to improved results. ${ }^{[12]}$

Table 1. Screening of Lewis acids in the reaction with acetophenone. ${ }^{\text {a] }}$

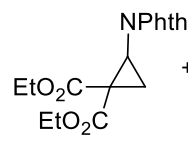

1a

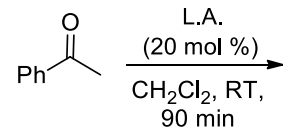

2a

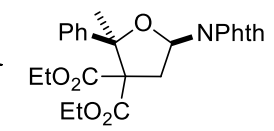

3aa

\begin{tabular}{ccc|ccc}
\hline entry & $\begin{array}{c}\text { Lewis } \\
\text { acid }^{[\mathrm{b}]}\end{array}$ & yield $(\%)^{[\mathrm{c}]}$ & entry & $\begin{array}{c}\text { Lewis } \\
\text { acid }^{[\mathrm{b}]}\end{array}$ & yield $(\%)^{[\mathrm{cc}]}$ \\
\hline 1 & $\mathrm{FeCl}_{3}-\mathrm{Al}_{2} \mathrm{O}_{3}$ & 20 & 5 & $\mathrm{In}(\mathrm{OTf})_{3}$ & 33 \\
2 & $\mathrm{SnCl}_{4}{ }^{\mathrm{dd}]}$ & 100 & 6 & $\mathrm{Sc}(\mathrm{OTf})_{3}$ & 25 \\
3 & $\mathrm{AuCl}_{3}$ & 50 & 7 & $\mathrm{Sn}(\mathrm{OTf})_{2}$ & 13 \\
4 & $\mathrm{Cu}(\mathrm{OTf})_{2}$ & 10 & 8 & $\mathrm{Hf}(\mathrm{OTf})_{4}$ & decomp. \\
\hline
\end{tabular}

[a] Reaction conditions: 1.0 equiv. 1a, 1.5 equiv. $2 \mathrm{a}, 20 \mathrm{~mol} \%$ of Lewis acid, $0.1 \mathrm{M}$ in dichloromethane. [b] No reaction with: $\mathrm{Zn}(\mathrm{OTf})_{2}, \mathrm{TiCl}_{4}, \mathrm{AuCl}, \mathrm{EtAlCl}_{2}, \mathrm{Me}_{2} \mathrm{AlCl}$, $\mathrm{CeCl}_{3}$. [c] Yield was determined via ${ }^{1} \mathrm{H}$ NMR spectroscopy using hexamethyldisiloxane as internal standard. [d] Performed at $-78{ }^{\circ} \mathrm{C}$; at RT, only traces of 3aa were detected. Phth $=$ phthaloyl. d.r. $=$ diastereomeric ratio. OTf $=$ trifluoromethanesulfonate.

Therefore, we selected $\mathrm{SnCl}_{4}$ as catalyst to further screen for the effects of temperature $(T)$ and catalyst loading on the diastereoselectivity of the $[3+2]$ annulation between $\mathbf{1 a}$ and acetophenone (2a) (Table 2). Using $5 \mathrm{~mol} \%$ of catalyst, the reaction showed a classic inverse d.r. dependence with respect to temperature, as the diastereoselectivity decreased with an increase in $T$. The 2,5-trans isomer epi-3aa became detectable in the crude when running the reaction at $-10{ }^{\circ} \mathrm{C}$ (entry 4). ${ }^{[13]}$ In the presence of $20 \mathrm{~mol} \mathrm{\%}$ of $\mathrm{SnCl}_{4}$, epi-3aa was already formed at $-20{ }^{\circ} \mathrm{C}$, although the increased amount of catalyst induced significant decomposition (entry 3). At $-10{ }^{\circ} \mathrm{C}$, it was the only diastereoisomer observed in the crude reaction mixture (entry 4). Unfortunately, the isolated yield under these conditions was poor (19\%), hampering the development of a temperature-dependent synthesis of both diastereoisomers of aminoTHFs. To verify if epi-3aa could derive from 3aa via a tin(IV)-catalyzed isomerization, aminotetrahydrofuran 3aa was treated with 20 mol $\% \mathrm{SnCl}_{4}$ at $-10{ }^{\circ} \mathrm{C}$. In this case, mainly its partial conversion in starting material 1a, likely via a retro-[3+2] annulation, was observed. To explain this result, we assume that 3aa might isomerize to epi-3aa via a sequence of retro-[3+2] annulation/[3+2] annulation (Scheme 3). ${ }^{[14]}$ As intermediates, both an intimate ion pair Ia or a completely dissociated zwitterion Ib could be considered. In the presence of 1 equiv of $\mathbf{2 a}$, full conversion of 3aa was achieved and epi-3aa was obtained in $45 \%$ yield. Although this result would be in good agreement with a process having Ia or Ib as intermediate, as a higher concentration of 2a would be particularly important to allow efficient isomerization in this case, the interconversion of the open zwitterions II and III or the reaction of $\mathbf{~ a ~ o r ~ I b ~ w i t h ~}$ acetophenone (2a) to give 3aa directly are also possible reaction pathways.

Table 2. Diastereomeric ratios observed in the reaction of 1a with 2a with 5-20 $\mathrm{mol} \%$ of $\mathrm{SnCl}_{4}$ depending on the temperature. ${ }^{[\mathrm{a}]}$

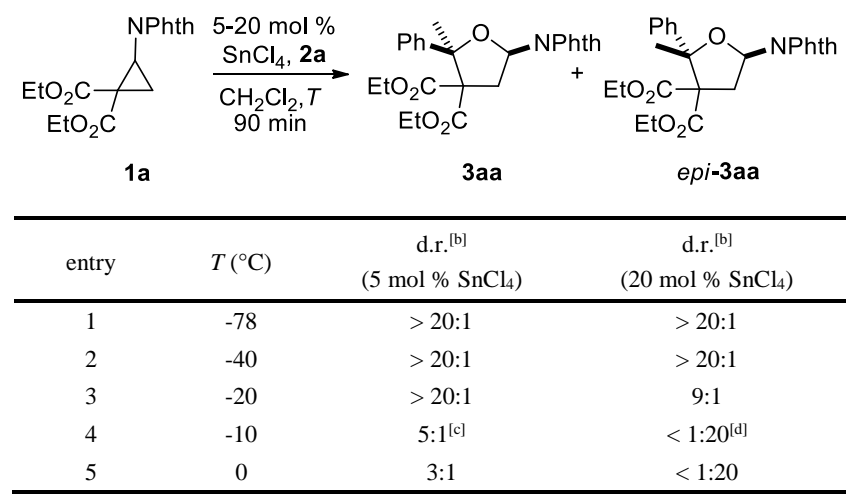

[a] Reaction conditions: 1.0 equiv. 1a, 1.5 equiv. 2 a, $5-20 \mathrm{~mol} \%$ of $\mathrm{SnCl}_{4}, 0.1 \mathrm{M}$ in dichloromethane at the indicated $T$. [b] Determined by ${ }^{1} \mathrm{H}$ NMR spectroscopy on the crude reaction mixture and expressed as cis:trans (3aa:epi-3aa). [c] 80\% combined isolated yield. [d] 19\% isolated yield. Phth $=$ phthaloyl. d.r. $=$ diastereomeric ratio.

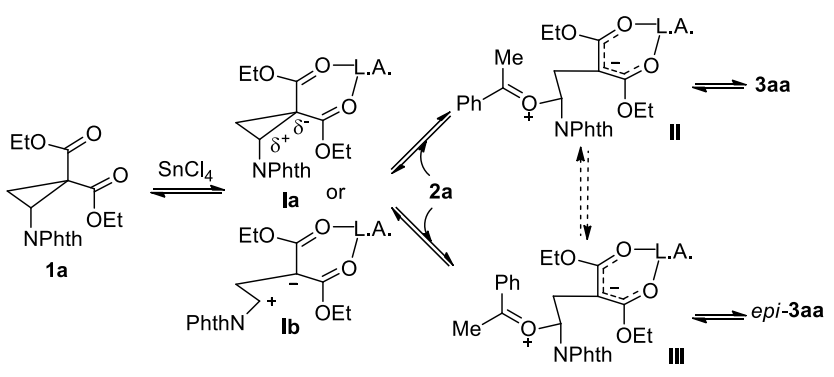

Scheme 3. Formation of tetrahydrofurans 3aa and epi-3aa via [3+2] annulation. Phth $=$ phthaloyl. L.A. $=$ Lewis acid.

Next, the scope of the reaction was evaluated by applying the optimized conditions to a variety of aromatic, heteroaromatic and aliphatic ketones (Table 3). D-A cyclopropanes $\mathbf{1 a}$ and $\mathbf{1 b}$ displayed a similar reactivity toward acetophenone (2a), affording aminoTHFs 3aa and 3ba in excellent yields and diastereoselectivity (entries 1-2). ${ }^{[15]}$ A lower yield (79\%, entry 3) was obtained in the case of 1 '-acetonaphthone (2b), most likely due to the unfavourable ortho substitution. Electron-rich aromatic ketone 2c and heteroaromatic 2d showed lower diastereoselectivities for the [3+2] annulation (entries 4-5). Nevertheless, the d.r. could be improved through a single recrystallization.

Electron-poor aromatic ketones 2e-f were also tested, and they gave the corresponding aminoTHFs $3 \mathbf{b e}$ and $\mathbf{3 b f}$ in high yields, as single diastereoisomers (entries 6-7). Excellent stereochemical discrimination between the phenyl and the ethyl substituent was observed also with propiophenone (2g), demonstrating the versatility of our methodology (entry 8). 1-Tetralone (2h) displayed excellent reactivity and selectivity, delivering $\mathbf{3 a h}$ in 
high yield and diastereoselectivity, but favouring the 2,5-trans isomer for this cyclic system (entry 9). ${ }^{[16]}$ Aliphatic symmetric ketones $(\mathbf{2} \mathbf{i}-\mathbf{j})$ are more established substrates in [3+2] annulation with D-A cyclopropanes. Under our conditions, they cleanly afforded the corresponding aminoTHFs in nearly quantitative yields (entries 10-12). In general, obtaining a high degree of diastereocontrol when employing non-symmetric aliphatic ketones remains a challenge. Gratifyingly, utilizing our optimized conditions on ketones 2k-l gave yields and diastereoselectivities comparable to those obtained with aromatic substrates (entries 1314). Ketone substrate $\mathbf{2 k}$ highlights the efficacy of the developed methodology as a good d.r. (10:1, entry 13) was obtained with two carbonyl substituents, methyl and ethyl, possessing only a small difference in size.

Table 3. Scope of the $[3+2]$ annulation with ketones. ${ }^{[a]}$
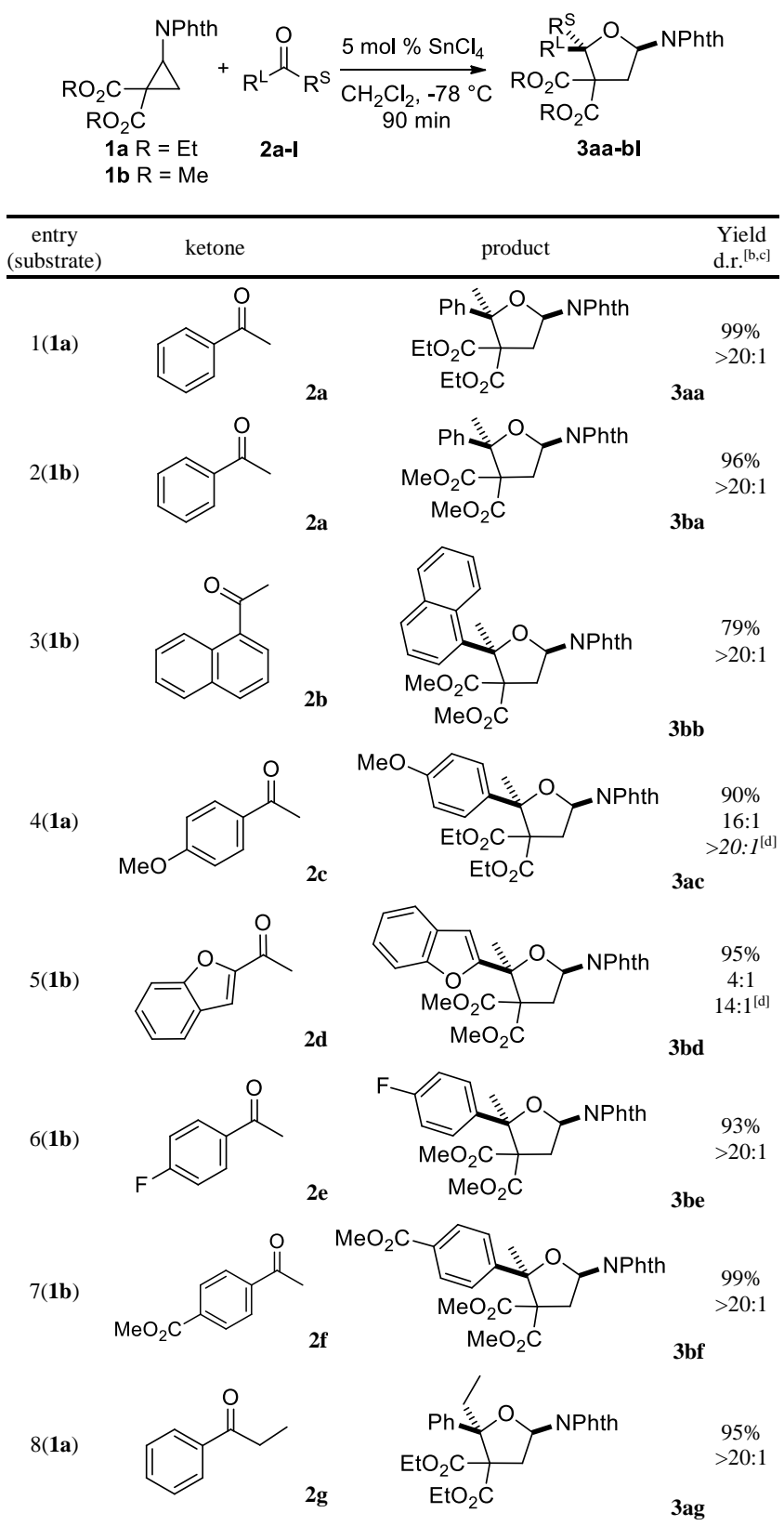

$9(\mathbf{1 a})$<smiles>O=C1CCCc2ccccc21</smiles>
$2 \mathrm{~h}$

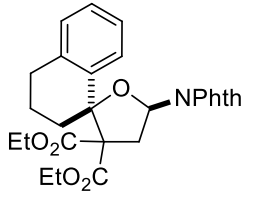

10(1a)<smiles>CC(C)=O</smiles><smiles>CCOC(=O)C1(C)CC([NH+]=P)OC1(C)C</smiles>

11(1a)<smiles>O=C1CCCCC1</smiles>

$2 j$<smiles>CCOCC1(C)CC([NH2+]c2ccccc2)OC1(C)OCC</smiles>

12(1b)<smiles>O=C1CCCCC1</smiles>

13(1b)<smiles>CCC(C)=O</smiles><smiles>CCCCC1(CC)OC([NH+]c2ccccc2)CC1(CCCC)C(OC)OC</smiles>
3bj

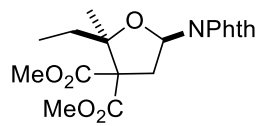

3bk

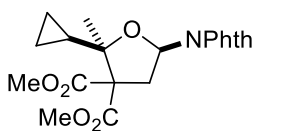

$94 \%$ $>20:$

3ah $94 \%$

3ai $99 \%$

3aj $99 \%$

14(1b)<smiles>CC(=O)C1CC1</smiles>

[a] Standard reaction conditions: $0.2 \mathrm{mmol} \mathrm{1a-b,} 1.5$ equiv. 2a-1, $5 \mathrm{~mol} \%$ of $\mathrm{SnCl}_{4}$, $0.1 \mathrm{M}$ in dichloromethane at $-78^{\circ} \mathrm{C}$. [b] Determined by ${ }^{1} \mathrm{H}$ NMR spectroscopy on the crude reaction mixture. [c] Expressed as cis:trans. [d] Obtained after one single recrystallization (see supporting information). $\mathrm{Phth}=$ phthaloyl. d.r. $=$ diastereomeric ratio. $\mathrm{R}^{\mathrm{L}}=$ Larger substituent. $\mathrm{R}^{\mathrm{S}}=$ Smaller substituent.

To assess the stereospecificity of the tin(IV)-catalysed [3+2] annulation, a selection of ketones was reacted with enantioenriched phthaloyl cyclopropane 1a at $-78{ }^{\circ} \mathrm{C}$ (Scheme 4). ${ }^{[17]}$ Under these conditions, no loss of stereochemical purity was observed with acetophenone (2a) and ketones $\mathbf{2} \mathbf{h}-\mathbf{j}$, while aminotetrahydrofuran 3ag was isolated with a slightly decreased enantiomeric excess (enantiospecificity e.s. $=83 \%$ )

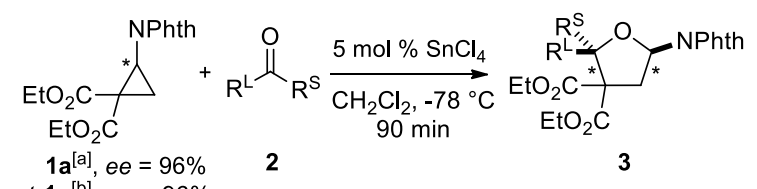

ent $-1 \mathrm{a}^{[\mathrm{b}]}$,ee $=96 \%$
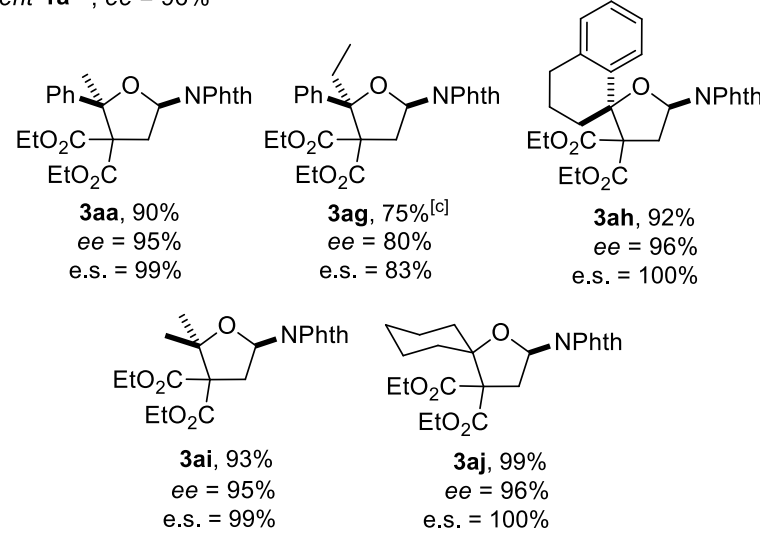

Scheme 4. Enantiospecific [3+2] annulation of D-A aminocyclopropanes 1a with ketones. [a] Used in combination with $\mathbf{2 a}, \mathbf{2 g}$ and $\mathbf{2 i}$. [b] Used in combination with $\mathbf{2 h}$ and $\mathbf{2 j}$. [c] 99\% yield based on recovered starting material. $\mathrm{Phth}=$ phthaloyl. $\mathrm{R}^{\mathrm{L}}=$ Larger substituent. $\mathrm{R}^{\mathrm{S}}=$ Smaller substituent. $e e=$ enantiomeric excess. e.s. $=$ enantiospecificity ([ee of product/ $e e$ of starting material $] * 100 \%$ ). 
The preservation of optical purity in [3+2] annulations of DA- cyclopropanes was already reported by Johnson ${ }^{[3 \mathrm{~h}-\mathrm{i}, 1]}$ and by our group; ${ }^{[7 \mathrm{e}]}$ nevertheless, this is the first enantiospecific reaction between aminocyclopropanes and carbonyl compounds. ${ }^{[18]}$ This result is not only important for the application of the reaction in the synthesis of enantioenriched products, it also demonstrated that an open zwitterion (Ib in Scheme 3) is not formed during the annulation.

Based on the high enantiospecificity and diastereoselectivity of the reaction, we wondered if the reaction of racemic 1a with a chiral ketone would allow for a kinetic resolution to take place. For example, the reaction of cyclopropane 1a with (-)-menthone (2m) should in principle favour the formation of the two diastereoisomers 3am and 3am', as both have the phthalimide group in cis relationship to the more bulky group (Scheme 5, A). Both products would be obtained as single enantiomers, as enantiopure (-)-menthone (2m) is used as starting material. The opposite absolute stereochemistry at the nitrogen center would result from the enantiospecific reaction of both enantiomers of 1a. ${ }^{[19]}$ However, a severe steric interaction between the ester and the isopropyl group of (-)-menthone (2m) is present only in 3am': the formation of this diastereoisomer is consequently expected to be slower (mismatched case), allowing a kinetic resolution with re-isolation of enantioenriched 1a. Unfortunately, the kinetic resolution of 1a using sub-stoichiometric amount of (-)-menthone (2m) could not be accomplished, mainly due to the sluggish reactivity observed in this case. When increasing to 3 equivalents the amount of $\mathbf{2 m}$, the reaction was accelerated, allowing the isolation of enantioenriched 1a after $1 \mathrm{~h}$, although yield and enantiomeric excess showed a strong batch dependency (Scheme 5 , B). Unexpectedly, after the conversion was complete $(2 \mathrm{~h})$, the annulation product 3am was isolated as a single diastereoisomer in $88 \%$ yield. Consequently, the reaction was not enantiospecific, but stereoconvergent. [20]

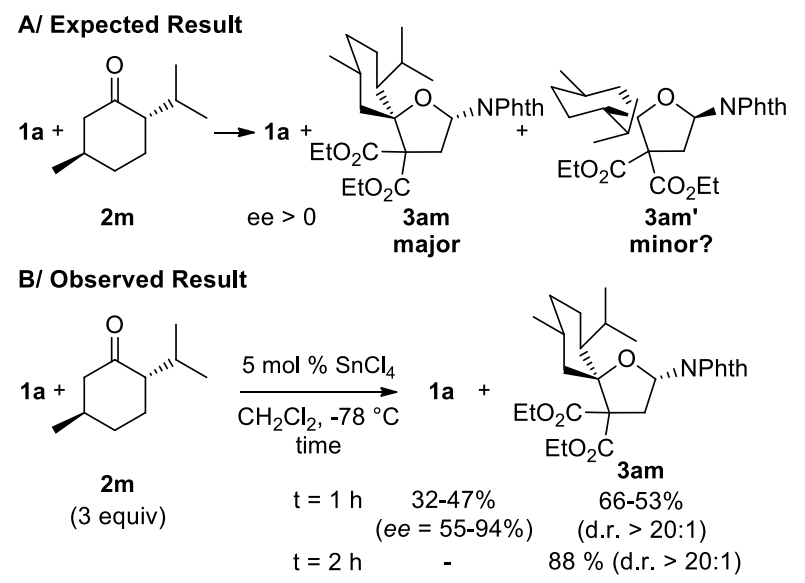

Scheme 5. Reaction of racemic 1a with (-)-menthone (2m). Phth = phthaloyl. $e e=$ enantiomeric excess. d.r. = diastereomeric ratio.

Different rationales could account for this result: tin(IV) chloride is either active in the racemization of the D-A aminocyclopropane 1a or in the isomerization of the product 3am. To obtain additional clues, the loss of enantiomeric purity of enantioenriched 1a $(e e=94 \%)$ in the presence of $5 \mathrm{~mol} \% \mathrm{SnCl}_{4}$ was monitored at $-78{ }^{\circ} \mathrm{C}$. After one hour, 1a was recovered with an $e e=75 \%$, while after 2.5 hours almost all its stereochemical information was lost $(e e=20 \%) \cdot{ }^{[3 \mathrm{i}, 21]}$ This result supports the hypothesis that the observed dynamic kinetic resolution could take place via racemization of the aminocyclopropane 1a, probably via an open zwitterionic intermediate Ib (Scheme 3) The apparently contradicting results obtained with (-)-menthone (2m) could be explained by a limited lifetime for a tight ion-pair Ia: If the following annulation reaction is fast, an enantiospecific reaction takes place, but if the desired reaction is slow, as for the mismatched case with (-)-menthone (2m), dissociation would have time to occur, which would lead to racemization even at $78{ }^{\circ} \mathrm{C}$ and to the stereoconvergent reaction observed. In contrast, the cis-trans isomerization described in table 2 would require higher temperature to proceed. We note that further experiments would be required to confirm this interpretation.

In conclusion, we have reported the first enantiospecific [3+2] annulation of D-A cyclopropanes with ketones. Catalytic amounts of tin(IV) chloride were used to catalyze the reaction with a broad range of ketones, including non-symmetric ones. Yields and diastereomeric ratios were generally excellent, demonstrating the potential of this method for the stereoselective synthesis of aminoTHFs bearing a rare C5-quaternary center. Furthermore, the developed transformation is enantiospecific, allowing access to enantioenriched aminoTHFs when starting from an enantioenriched aminocyclopropane.

Attempts to expand the scope of $\mathrm{N}$-containing cyclopropanes, as well as further functionalization of the obtained products are currently under evaluation in our laboratory.

\section{Experimental Section}

In a two-neck flask equipped with a nitrogen inlet, aminocyclopropanes 1a-b $(0.20$ mmol, 60-66 mg, 1 equiv.) and ketones 2a-l (1.5 equiv.) were dissolved in anhydrous dichloromethane $(2 \mathrm{~mL})$ at $-78{ }^{\circ} \mathrm{C}$. After $5 \mathrm{~min}, \mathrm{SnCl}_{4}(5 \mathrm{~mol} \%, 0.01 \mathrm{mmol}, 23 \mu \mathrm{L}$ of $0.43 \mathrm{~m}$ solution in dichloromethane) was added. The mixture was stirred under nitrogen at $-78^{\circ} \mathrm{C}$ for $90 \mathrm{~min}$, then it was quenched by the addition of triethylamine $(0.2 \mathrm{~mL})$ and subsequently flushed through a short plug of silica gel, eluting with EtOAc $(5 \mathrm{~mL})$. The solvent was removed in vacuo, affording the crude reaction mixture, which was submitted to ${ }^{1} \mathrm{H}$ NMR analysis to determine the d.r. before purification via flash chromatography $\left(\mathrm{SiO}_{2}, 8 / 2\right.$ to $1 / 1$ ( $n$-hexane: $\left.\left.\mathrm{AcOEt}\right)\right)$.

\section{Acknowledgements}

We thank the European Commission (Marie Curie IEF fellowship to F.B., grant number 253274) and the Swiss National Science Foundation (SFN, grant number 200021_129874) for financial support. Dr. Rosario Scopelliti (EPFL) is acknowledged for the X-ray studies. We thank Dr. Reto Frei for proofreading the manuscript.

Keywords: D-A aminocyclopropane $\bullet$ ketone $\bullet$ catalysis • enantiospecificity $\bullet$ aminotetrahydrofuran $\bullet$ $[3+2$ ]annulation

[1] For reviews on D-A cyclopropanes, see: (a) H. U. Reissig, R. Zimmer, Chem. Rev 2003, 103, 1151-1196. (b) M. Yu, B. L. Pagenkopf, Tetrahedron 2005, 61, 321-347. (c) F. De Simone, J. Waser, Synthesis 2009, 3353-3374. Theoretical study: (d) T. F. Schneider, D. B. Werz, Org. Lett. 2011, 13, 18481851 .

[2] Reviews: (a) C. A. Carson, M. A. Kerr, Chem. Soc. Rev. 2009, 38, 3051-3060. (b) M. J. Campbell, J. S. Johnson, A. T. Parsons, P. D. Pohlhaus, S. D. Sanders, J. Org. Chem. 2010, 75, 6317-6325. (c) T. P. Lebold, M. A. Kerr, Pure Appl. Chem. 2010, 82, 1797-1812. (d) V. K. Yadav, N. V. Kumar, Chem. Comm. 2008, 6471-6478. (e) O. A. Ivanova, E. M. Budynina, A. O Chagarovskiy, I. V. Trushkov, M. Y. Melnikov, J. Org. Chem 2011, 76, 8852-8868. A reviewer proposed to use the term [3+2] cycloaddition for this type of reaction, as it is more precise than annulation, and could be in agreement with the IUPAC definition for cycloaddition: " A reaction in which two or more unsaturated molecules (or parts of the same molecule) combine with the formation of a cyclic adduct in which there is a net reduction of the bond multiplicity." Nevertheless, other authors do not agree 
that "cycloaddition" is completely correct in this case (see reference 2b). According to a seminal publication of Huisgen, "Cycloaddition reactions do not involve the cleavage of sigma bonds" (rule 3): (f) R. Huisgen, Angew. Chem., Int. Ed. 1968, 7, 321-406. In view of this controversy, we still kept the term annulation throughout our publication, as it is accepted as correct by all scientists in the field. We let the reader make his own choice if he prefers to use the word cycloaddition.

[3] Examples with aldehydes: (a) H. U. Reissig, Tetrahedron Lett. 1981, 22, 2981-2984. (b) H. U. Reissig, H. Holzinger, G. Glomsda, Tetrahedron 1989, 45, 3139-3150. (c) S. Shimada, Y. Hashimoto, A. Sudo, M. Hasegawa, K. Saigo, J. Org. Chem 1992, 57, 7126-7133. (d) S. Shimada, Y. Hashimoto, T. Nagashima, M. Hasegawa, K. Saigo, Tetrahedron 1993, 49, 1589-1604. (e) S Shimada, Y. Hashimoto, K. Saigo, J. Org. Chem 1993, 58, 5226-5234. (f) Y. Sugita, K. Kawai, I. Yokoe, Heterocycles 2001, 55, 135-144. (g) Z. Han, S. Uehira, T. Tsuritani, H. Shinokubo, K. Oshima, Tetrahedron 2001, 57, 987995. (h) P. D. Pohlhaus, J. S. Johnson, J. Am. Chem. Soc. 2005, 127, 1601416015. (i) P. D. Pohlhaus, S. D. Sanders, A. T. Parsons, W. Li, J. S. Johnson, J. Am. Chem. Soc. 2008, 130, 8642-8650. (j) A. T. Parsons, J. S. Johnson, J. Am. Chem. Soc. 2009, 131, 3122-3123. (k) T. F. Schneider, J. Kaschel, B. Dittrich, D. B. Werz, Org. Lett. 2009, 11, 2317-2320. (1) C. Brand, G. Rauch, M. Zanoni, B. Dittrich, D. B. Werz, J. Org. Chem 2009, 74, 8779-8786. (m) S. Xing, W. Pan, C. Liu, J. Ren, Z. Wang, Angew. Chem. Int. Ed. 2010, 49, 3215-3218. (n) A. G. Smith, M. C. Slade, J. S. Johnson, Org. Lett. 2011, 13, 1996-1999. Examples with ketones: (o) E. Nakamura, I. Kuwajima, J. Am. Chem. Soc. 1977, 99, 7360-7362. (p) A. R. Daniewski, T. KowalczykPrzewloka, J. Org. Chem. 1985, 50, 2976-2980. (q) E. Nakamura, H. Oshino, I. Kuwajima, J. Am. Chem. Soc. 1986, 108, 3745-3755. (r) C. Brueckner, H. Holzinger, H. U. Reissig, J. Org. Chem. 1988, 53, 2450-2456. (s) S. Shimada, Y. Hashimoto, A. Sudo, M. Hasegawa, K. Saigo, J. Org. Chem 1992, 57, 7126-7133. Thermal [3+2] annulation: (t) S. Yamago, E. Nakamura, J. Org. Chem 1990, 55, 5553-5555. Some examples with ketones can be found also in references $3 \mathrm{a}-\mathrm{b}$.

[4] Catalytic reactions with ketones as partners: (a) E. O. Martins, J. L. Gleason, Org. Lett. 1999, 1, 1643-1645. (b) Y. Sugita, K. Kawai, I. Yokoe, Heterocycles 2000, 53, 657-664. (c) M. Shi, B. Xu, Tetrahedron Lett. 2003, 44, 3839-3842. (d) A. Gupta, V. K. Yadav, Tetrahedron Lett. 2006, 47, 80438047. (e) Xing, S., Li, Y., Li, Z., Liu, C., Ren, J. and Wang, Z. Angew. Chem., Int. Ed. 2011, 50, 12605-12609. A single example of a catalytic reaction with acetone was also reported by Johnson and coworkers: see ref. $3 \mathrm{i}$.

[5] For a review on the stereoselective synthesis of tetrahydrofurans, see: J. P. Wolfe, M. B. Hay, Tetrahedron 2007, 63, 261-290.

[6] The highest d.r. obtained in catalytic reactions with prochiral ketones is $3.7: 1$ for intermolecular reactions (ref. 4d) and >95:5 for intramolecular ones (ref. $4 \mathrm{e})$.

[7] Intramolecular formal homo-Nazarov: (a) F. De Simone, J. Waser, Synthesis 2009, 2009, 3353-3374. (b) F. De Simone, J. Gertsch, J. Waser, Angew. Chem. Int. Ed. 2010, 49, 5767-5770. (c) F. De Simone, J. Waser, Synlett 2011 589-593. (d) F. De Simone, T. Saget, F. Benfatti, S. Almeida, J. Waser, Chem. Eur. J. 2011, 17, 14527-14538. Intermolecular [3+2] annulation with silyl enol ethers: (e) F. de Nanteuil, J. Waser, Angew. Chem. Int. Ed. 2011, 50, 12075-12079. With aldehydes: (f) F. Benfatti, F. de Nanteuil, J. Waser, Org. Lett. 2012, 14, 386-389..

[8] Intermolecular: (a) K. Wimalasena, H. B. Wickman, M. P. D. Mahindaratne,. Eur. J. Org. Chem. 2001, 3811-3817. (b) C. Tanguy, P. Bertus, J. Szymoniak, O. V. Larionov, A. de Meijere, Synlett 2006, 2006, 2339-2341.
Intramolecular: (c) C. Bubert, C. Cabrele, O. Reiser, Synlett 1997, 1997, 827 829. (d) H. B. Lee, M. J. Sung, S. C. Blackstock, J. K. Cha, J. Am. Chem. Soc 2001, 123, 11322-11324. (e) L. Larquetoux, N. Ouhamou, A. Chiaroni, Y. Six, Eur. J. Org. Chem. 2005, 4654-4662. (f) S. Mangelinckx, N. De Kimpe, Synlett 2005, 1521-1526. Applications in total synthesis: (g) D. Zhang, H Song, Y. Qin, Acc. Chem. Res. 2011, 44, 447-457. For reviews on aminocyclopropanes, see: (h) F. Gnad, O. Reiser, Chem. Rev 2003, 103 , 1603-1624. (i) F. Brackmann, A. de Meijere, Chem. Rev 2007, 107, 44934537.

[9] Modified Nucleosides: in Biochemistry, Biotechnology and Medicine, (Ed: P. Herdewijn), WILEY-VCH, Weinheim, 2008.

[10] A 2-aminoTHF substructure search on PubChem Compound database gave $>164,000$ entries for the compounds with tertiary C5 (3299 active in bioassays), and 3 entries for those with quaternary C5. For PubChem Compound database see: E. Bolton, Y. Wang, P. A.Thiessen, S. H. Bryant, in Annual Reports in Computational Chemistry, Vol. 4, AMERICAN CHEMICAL SOCIETY, Washington, DC, 2008.

[11] The crystal structure of $\mathbf{3 a a}$ has been deposited at the Cambridge Crystallographic Data Centre and allocated the deposition number: CCDC 858768.

[12] All the Lewis acid that gave some conversion afforded 3aa as a single diastereoisomer, except $\mathrm{FeCl}_{3}-\mathrm{Al}_{2} \mathrm{O}_{3}$ and $\mathrm{Sc}(\mathrm{OTf})_{3}$ (see supporting information for details)

[13] The crystal structure of epi-3aa has been deposited at the Cambridge Crystallographic Data Centre and allocated the deposition number: CCDC 858769.

[14] According to Johnson and coworkers (ref. 3i), intermediates II and III would afford respectively the 2,5-cis tetrahydrofuran $\mathbf{3 a a}$ and the 2,5-trans tetrahydrofuran epi-3aa. Nevertheless, pathways leading from II to epi-3aa and from III to 3aa could also be conceived.

[15] 2,5-relative stereochemistry was assigned on the basis of $\mathrm{x}$-ray diffraction analysis performed on compound 3aa and extended to the other compounds of the series (3bb-3am) on the basis of the regularity in their NMR spectra.

[16] See supporting information for details

[17] Enantioenriched 1a was obtained by preparative HPLC separation on chiral stationary phase (see supporting information for details).

[18] The [3+2] annulation of aminocyclopropanes with aldehydes was not enantiospecific (see ref. 7f).

[19] The most probable stereochemical course for the enantiospecific reaction is inversion of the stereochemistry next to nitrogen, as observed by Johnson (see reference $2 b$ ). However, this still needs to be established experimentally and will be the topic of further investigation in our laboratory.

[20] The crystal structure of $\mathbf{3} \mathbf{a m}$ has been deposited at the Cambridge Crystallographic Data Centre and allocated the deposition number: CCDC 861951.

[21] K. Sapeta, M. A. Kerr, J. Org. Chem 2007, 72, 8597-8599.

Received: ((will be filled in by the editorial staff))

Revised: ((will be filled in by the editorial staff)) Published online: ((will be filled in by the editorial staff)) 


\section{Enantiospecific Annulation}

Fides Benfatti, Florian de Nanteuil and Jérôme Waser* Page - Page

Catalytic Enantiospecific [3+2]

Annulation of

Aminocyclopropanes with

Ketones

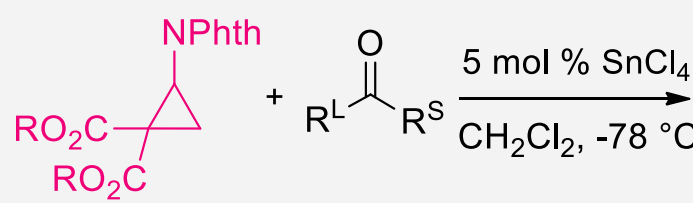

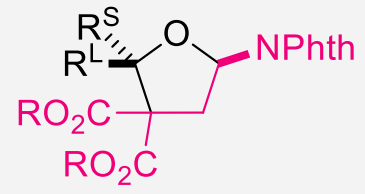

$79-99 \%$

15 examples

The first enantiospecific $[3+2] \quad-78 \quad{ }^{\circ} \mathrm{C}$ and gives aminotetraannulation of D-A amino- hydrofurans bearing a C5-quaternary cyclopropanes with ketones is stereocenter in high yield, reported herein (see scheme; Phth $=$ diastereoselectivity and enantiophthaloyl). The reaction is catalyzed specificity.

by $5 \mathrm{~mol} \%$ of tin(IV) chloride at 


\section{Table of contents}

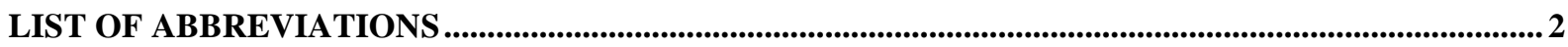

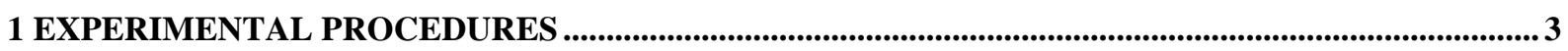

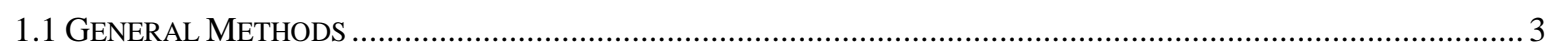

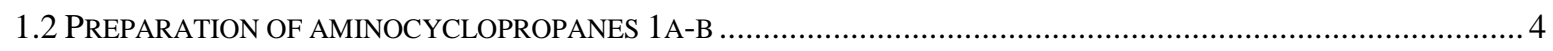

1.3 STANDARD PROCEDURE FOR THE SCREENING OF LEWIS ACIDS .............................................................5

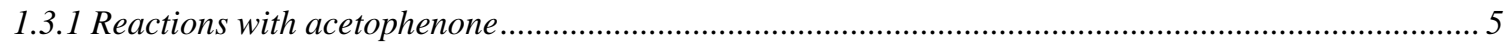

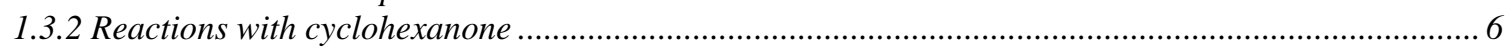

1.4 STANDARD PROCEDURE FOR TESTING THE DEPENDENCE OF D.R. ON TEMPERATURE AND SNCL4 LOADING

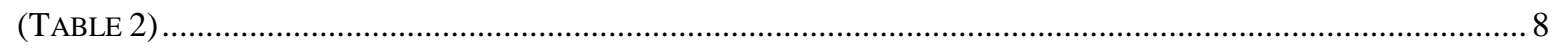

1.5 STANDARD PROCEDURE FOR THE SNCL4-CATALYSED [3+2] ANNULATION OF AMINOCYCLOPROPANES WITH

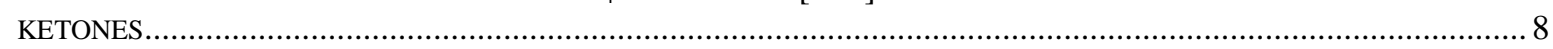

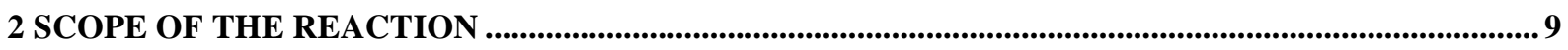

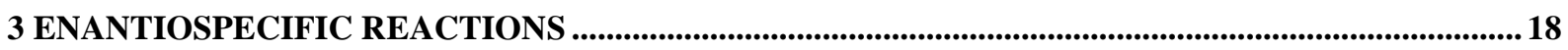

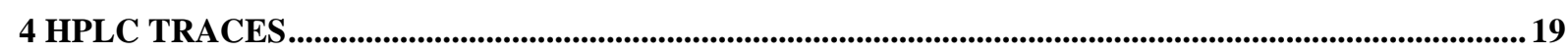

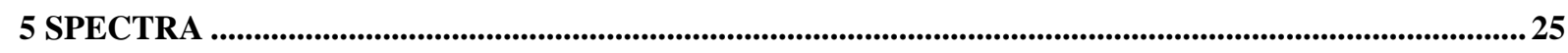

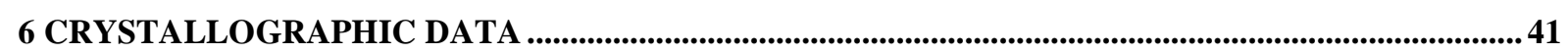




\section{List of Abbreviations}

$\begin{array}{ll}\text { Ac } & \text { acetyl } \\ \text { DCM } & \text { dichloromethane } \\ \text { d.r. } & \text { diastereomeric ratio } \\ \text { eq } & \text { equivalent } \\ \text { ESI } & \text { Electrospray Ionization } \\ \text { Et } & \text { ethyl } \\ \text { h } & \text { hours } \\ \text { hept } & \text { heptet } \\ \text { HPLC } & \text { High Performance Liquid Chromatography } \\ \text { HRMS } & \text { High Resolution Mass Spectra } \\ \text { iPr } & \text { isopropyl } \\ \text { M } & \text { molar mol/L } \\ \text { Me } & \text { methyl } \\ \text { Mp } & \text { melting point } \\ \text { MS } & \text { Mass Spectrometry } \\ \text { NMR } & \text { Nuclear Magnetic Resonance } \\ \text { OTf } & \text { Trifluoromethanesulfonate } \\ \text { Ph } & \text { phenyl } \\ \text { Phth } & \text { phthaloyl } \\ \mathrm{R}_{\mathrm{f}} & \text { Retention Factor } \\ \mathrm{rt} & \text { room temperature } \\ \text { TMS } & \text { trimethylsilyl }\end{array}$




\section{Experimental procedures}

\subsection{General Methods}

All reactions were carried out in oven dried glassware under an atmosphere of nitrogen, unless stated otherwise. For quantitative flash chromatography technical grade solvents were used. For flash chromatography for analysis, HPLC grade solvents from Sigma-Aldrich were used. $\mathrm{CH}_{2} \mathrm{Cl}_{2}$ was dried by passage over activated alumina under nitrogen atmosphere $\left(\mathrm{H}_{2} \mathrm{O}\right.$ content $<30$ ppm, Karl-Fischer titration). All chemicals were purchased from Acros, Aldrich, Fluka, VWR, Aplichem or Merck and used as such unless stated otherwise. Chromatographic purification was performed as flash chromatography using Macherey-Nagel silica 40-63, 60 $\AA$, using the solvents indicated as eluent with 0.1-0.5 bar pressure. TLC was performed on Merck silica gel 60 F254 TLC plastic plates and visualized with UV light, permanganate stain, CAN stain or Anisaldehyde stain. Melting points were measured on a calibrated Büchi B-540 melting point apparatus using open glass capillaries. ${ }^{1} \mathrm{H}-\mathrm{NMR}$ spectra were recorded on a Brucker DPX-400 $400 \mathrm{MHz}$ spectrometer in chloroform-d, all signals are reported in ppm with the internal chloroform signal at $7.26 \mathrm{ppm}$ as standard. The data is being reported as ( $\mathrm{s}$ = singlet, $\mathrm{d}=$ doublet, $\mathrm{t}=$ triplet, $\mathrm{q}=$ quadruplet, $\mathrm{qi}=$ quintet, $\mathrm{m}=$ multiplet or unresolved, br = broad signal, coupling constant(s) in $\mathrm{Hz}$, integration; interpretation). ${ }^{13} \mathrm{C}-\mathrm{NMR}$ spectra were recorded with 1H-decoupling on a Brucker DPX-400 $100 \mathrm{MHz}$ spectrometer in chloroform-d, all signals are reported in ppm with the internal chloroform signal at $77.0 \mathrm{ppm}$ as standard. Infrared spectra were recorded on a JASCO FT-IR B4100 spectrophotometer with an ATR PRO410-S and a ZnSe prisma and are reported as $\mathrm{cm}^{-1}$ ( $\mathrm{w}=$ weak, $\mathrm{m}=$ medium, $\mathrm{s}=$ strong, $\mathrm{sh}=$ shoulder). Gas chromatographic and low resolution mass spectrometric measurements were performed on a Perkin-Elmer Clarus 600 gas chromatographer and mass spectrometer using a Perkin-Elmer Elite fused silica column (length: $30 \mathrm{~m}$, diameter: 0.32 $\mathrm{mm})$ and Helium as carrier gas. High resolution mass spectrometric measurements were performed by the mass spectrometry service of ISIC at the EPFL on a MICROMASS (ESI) Q-TOF Ultima API. HPLC measurement were done on a JASCO HPLC system with an AS2055 Autosampler, a PU 2089 Pump, a UV 2075 detector and a SEDEX 85 (SEDERE) detector using a CHIRALPAK IC, IB or IA column from DAICEL Chemical Industries Ltd. HPLC grade solvents from Sigma-Aldrich were used. The ketones used in this study are all commercially available and were used as received. 


\subsection{Preparation of aminocyclopropanes $1 a-b$}

\section{Diethyl 2-(1,3-dioxoisoindolin-2-yl)cyclopropane-1,1-dicarboxylate (1a)}

Following a reported procedure ${ }^{[1]}$, a two-neck flask equipped with a nitrogen inlet was loaded with $14 \mathrm{mg} \quad(0.018 \mathrm{mmol}, \quad 0.1 \mathrm{~mol} \%)$ of $\operatorname{bis}\left[\operatorname{rhodium}\left(\alpha, \alpha, \alpha^{\prime}, \alpha^{\prime}\right.\right.$-tetramethyl-1,3benzenedipropionic acid)] inside the glove box, then the flask was sealed with a rubber septum and evacuated from the glove box. A solution of $N$-vinyl-phthalimide $(3.0 \mathrm{~g}, 18$ $\mathrm{mmol}, 1 \mathrm{eq})$ in $30 \mathrm{~mL}$ of dry dichloromethane was added to the flask and the resulting green suspension was cooled down to $0{ }^{\circ} \mathrm{C}$ with an ice/water bath. A solution of diethyl-2diazomalonate $^{[2]}(4.0 \mathrm{~g}, 21 \mathrm{mmol}, 1.2 \mathrm{eq})$ in $20 \mathrm{~mL}$ of dichloromethane was added over five minutes. When the addition was complete, the reaction was allowed to warm to room temperature. After $5 \mathrm{~h}$ at room temperature, the solvent was removed under reduced pressure and the crude was directly purified by column chromatography $\left(\mathrm{SiO}_{2}, 9 / 1\right.$ to $7 / 3$ (n-hexane: AcOEt). $5.4 \mathrm{~g} \mathrm{(16} \mathrm{mmol,} 90 \%$ yield) of $1 \mathbf{a}$ as a colorless solid were obtained.

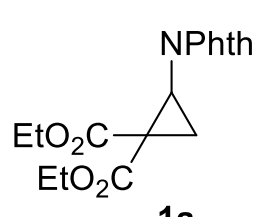

$1 \mathrm{a}$

$\mathbf{R}_{\mathbf{f}} 0.36(n$-hex/EtOAc 6/4);

Mp $93{ }^{\circ} \mathrm{C}$;

${ }^{1} \mathbf{H}$ NMR (400 MHz, $\left.\mathrm{CDCl}_{3}\right) \delta 7.85(\mathrm{~m}, 2 \mathrm{H}$, Phth), 7.74 (m, $2 \mathrm{H}$, Phth), $4.30\left(\mathrm{~m}, 2 \mathrm{H}, \mathrm{OCH}_{2}\right), 4.07\left(\mathrm{~m}, 2 \mathrm{H}, \mathrm{OCH}_{2}\right), 3.71(\mathrm{dd}, 1 \mathrm{H}, J=8.5,6.6 \mathrm{~Hz}$, $\mathrm{N}-\mathrm{C}-\mathrm{H}), 2.74\left(\mathrm{t}, 1 \mathrm{H}, J=6.5 \mathrm{~Hz}, \mathrm{CH}_{2}\right), 2.02\left(\mathrm{dd}, 1 \mathrm{H}, J=8.5,6.4 \mathrm{~Hz}, \mathrm{CH}_{2}\right), 1.34(\mathrm{t}, 3 \mathrm{H}, J=$ $\left.7.1 \mathrm{~Hz}, \mathrm{CH}_{3}\right), 1.12\left(\mathrm{t}, 3 \mathrm{H}, \mathrm{J}=7.1 \mathrm{~Hz}, \mathrm{CH}_{3}\right)$;

${ }^{13}$ C NMR (101 MHz, CDCl3) $\delta$ 168.2, 167.8, 166.4, 134.3, 131.6, 123.4, 62.0, 61.8, 34.7, $33.5,19.2,14.1,13.8$;

IR 2985 (w), 2938 (w), 2907 (w), 1783 (m), 1719 (s), 1614 (w), 1393 (s), 1321 (m), 1218 (s), $1133(\mathrm{~m}), 719(\mathrm{~s})$;

HRMS (ESI) calcd for $\mathrm{C}_{17} \mathrm{H}_{18} \mathrm{NO}_{6}{ }^{+}[\mathrm{M}+\mathrm{H}]^{+} 332.1129$; found 332.1135.

HPLC analysis: Chiracel IA $(0.46 \times 25 \mathrm{~cm}): 85: 15$ (hexane: $i$-PrOH), flow $1.0 \mathrm{~mL} / \mathrm{min} . \mathrm{t}_{1}: 9.0$ $\min , \mathrm{t}_{2}: 11.2 \mathrm{~min}$.

Preparative HPLC: Chiracel IA (20 x $250 \mathrm{~mm}), 85: 13.5: 1.5$ (hexane: AcOEt: $i$-PrOH), flow $10 \mathrm{~mL} / \mathrm{min} . \mathrm{t}_{1}=18 \mathrm{~min},[\alpha]_{\mathrm{D}}^{25} 115\left(\mathrm{er}: 98: 2, c 1.0, \mathrm{CHCl}_{3}\right), \mathrm{t}_{2}=24 \mathrm{~min},[\alpha]_{\mathrm{D}}^{25}-115$ (er: $98: 2$, c $\left.1.0, \mathrm{CHCl}_{3}\right)$.

Dimethyl 2-(1,3-dioxoisoindolin-2-yl)cyclopropane-1,1-dicarboxylate (1b)

[1] De Nanteuil, F.; Waser, J. Angew. Chem., Int. Ed. 2011, 50, 12075-12079.

[2] P. Wyatt, A. Hudson, J. Charmant, A. G. Orpen, H. Phetmung, Org. Biomol. Chem. 2006, 4, 2218 
Following the same procedure described above, using $2.5 \mathrm{~g}$ (14 mmol, 1 eq) of $N$-vinylphthalimide, $2.5 \mathrm{~g}$ (15 mmol, $1.1 \mathrm{eq})$ of dimethyl-2-diazomalonate and $11 \mathrm{mg}(0.014 \mathrm{mmol}$, $0.1 \mathrm{~mol} \%)$ of bis[rhodium( $\alpha, \alpha, \alpha^{\prime}, \alpha^{\prime}$-tetramethyl-1,3-benzenedipropionic acid)], $3.40 \mathrm{~g}$ (11.2 mmol, $78 \%$ yield) of $\mathbf{1 b}$ were isolated as a colorless solid.

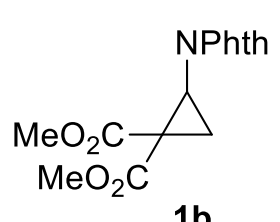

$$
\text { Rf } 0.27 \text { (n-hex/EtOAc 6/4); }
$$

Mp $124-125^{\circ} \mathrm{C}$;

${ }^{1} \mathbf{H}$ NMR (400 MHz, $\left.\mathrm{CDCl}_{3}\right) \delta 7.86(\mathrm{~m}, 2 \mathrm{H}$, Phth), 7.75 (m, $2 \mathrm{H}$, Phth),

$3.85(\mathrm{~s}, 3 \mathrm{H}, \mathrm{OMe}), 3.72(\mathrm{dd}, 1 \mathrm{H}, J=8.5,6.6 \mathrm{~Hz}, \mathrm{~N}-\mathrm{CH}), 3.64(\mathrm{~s}, 3 \mathrm{H}$,

OMe), $2.73\left(\mathrm{dd}, 1 \mathrm{H}, J=6.5,6.5 \mathrm{~Hz}, \mathrm{CH}_{2}\right), 2.06\left(\mathrm{dd}, 1 \mathrm{H}, J=8.5,6.4 \mathrm{~Hz}, \mathrm{CH}_{2}\right)$;

${ }^{13}$ C NMR $\left(101 \mathrm{MHz}, \mathrm{CDCl}_{3}\right) \delta 168.5,167.8,166.9,134.3,131.4,123.5,53.1,53.0,34.9$, 33.1, 19.6;

IR 2956 (w), 1783 (w), 1727 (s), 1468 (w), 1439 (w), 1399 (m), 1329 (m), 1294 (m), 1222 (m), $1134(\mathrm{w}), 909(\mathrm{w}), 876(\mathrm{w}), 720(\mathrm{~m})$;

HRMS (ESI) calcd for $\mathrm{C}_{15} \mathrm{H}_{14} \mathrm{NO}_{6}{ }^{+}[\mathrm{M}+\mathrm{H}]^{+}$304.0816; found 304.0804.

\subsection{Standard procedure for the screening of Lewis acids}

\subsubsection{Reactions with acetophenone}

All the reactions were carried out under nitrogen in glass vials equipped with rubber septa and Teflon-coated stir bars. The Lewis acid ( $4 \mu \mathrm{mol}, 20 \mathrm{~mol} \%$ ) was added to the vial in the glove box, followed by a solution of aminocyclopropane 1a (20 $\mu \mathrm{mol}, 6.6 \mathrm{mg}, 1$ equiv.) and acetophenone $2 \mathbf{a}(30 \mu \mathrm{mol}, 3.5 \mu \mathrm{L}, 1.5$ equiv.) in anhydrous dichloromethane $(0.1 \mathrm{M}, 0.2 \mathrm{~mL})$ was added under nitrogen. The mixture was stirred for $90 \mathrm{~min}$ at the indicated temperature, and then it was diluted with dichloromethane $(0.5 \mathrm{~mL})$ and flushed through a short plug of silica gel. The solvent was removed in vacuo, then a ${ }^{1} \mathrm{H}-\mathrm{NMR}$ sample was prepared by dissolving the crude mixture in $\mathrm{CDCl}_{3}(0.7 \mathrm{~mL})$ and a standard hexamethyldisiloxane solution $(0.01 \mathrm{M}, 0.111 \mathrm{~mL})$ was added. The ${ }^{1} \mathrm{H}-\mathrm{NMR}$ yield was calculated according to the following calibration curve.

\section{$\underline{{ }^{1} \mathrm{H}-\mathrm{NMR} \text { calibration curve }}$}

Hexamethyldisiloxane $(4.3 \mu \mathrm{L}, 0.02 \mathrm{mmol})$ was dissolved in $\mathrm{CDCl}_{3}(2.0 \mathrm{~mL})$, to give a 0.01 M standard solution. Compound 3aa $(4.5 \mathrm{mg}, 0.01 \mathrm{mmol})$ was dissolved in $\mathrm{CDCl}_{3}(0.7 \mathrm{~mL})$, then the following volumes of standard $0.01 \mathrm{M}$ solution were added: $55.0 \mu \mathrm{L}$ for sample A $(0.55 \mu \mathrm{mol}) ; 13.2 \mu \mathrm{L}$ for sample B $(0.13 \mu \mathrm{mol}) ; 23.1 \mu \mathrm{L}$ for sample $\mathrm{C}(0.23 \mu \mathrm{mol}) ; 46 \mu \mathrm{L}$ for sample D $(0.46 \mu \mathrm{mol}) ; 139 \mu \mathrm{L}$ for sample E $(1.39 \mu \mathrm{mol})$. 
${ }^{1} \mathrm{H}$ NMR spectra were acquired for solution A-E, and the ratios between the integrals of the signal at $\delta 6.31(\mathrm{dd}, 1 \mathrm{H}, J=8.2,7.0 \mathrm{~Hz}, C H \mathrm{NPhth})$ of 3aa and the signal at $\delta 0.06(\mathrm{~s}, 1 \mathrm{H}$, TMS) of hexamethyldisiloxane were determined. These experimental ratios were plotted vs. the ratios mmol 3aa / mmol hexamethyldisiloxane to give the calibration graph.

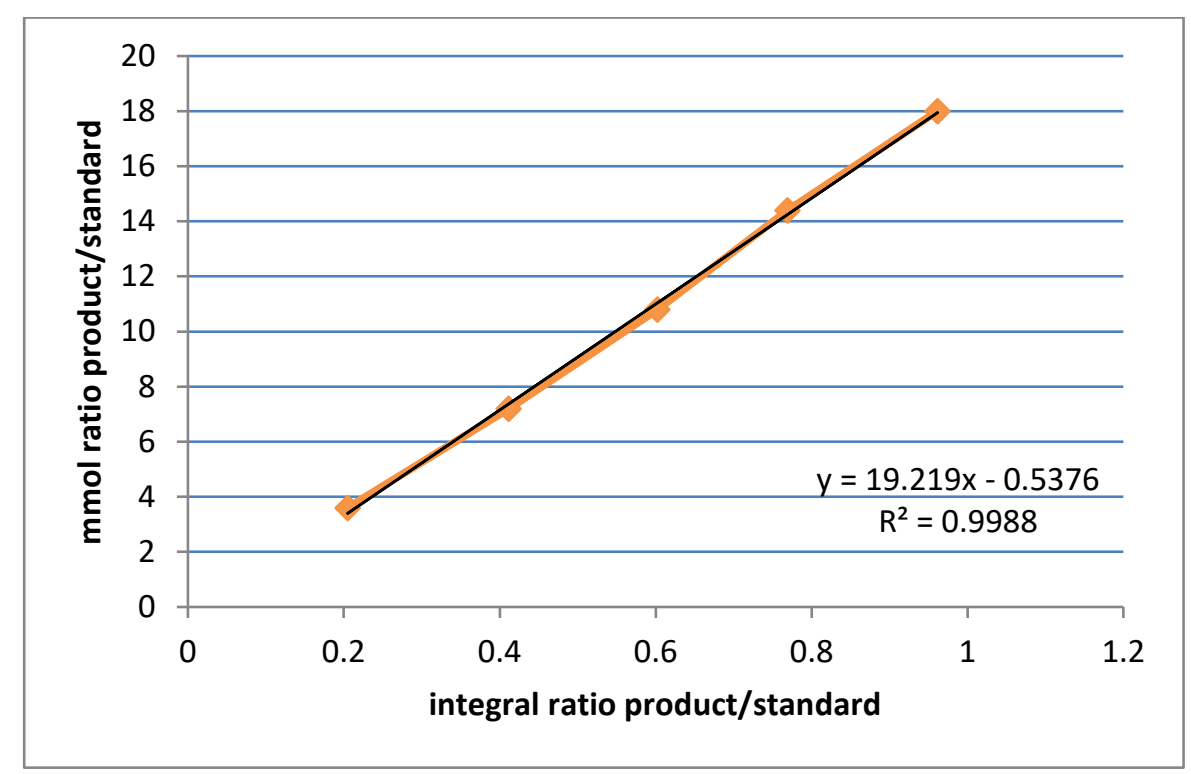

Table S1. Screening of Lewis Acids in the reaction with acetophenone. ${ }^{[a]}$

\begin{tabular}{cccc}
\hline entry & Lewis acid & yield $(\%)$ & d.r. (cis:trans) \\
\hline 1 & $\mathrm{FeCl}_{3}-\mathrm{Al}_{2} \mathrm{O}_{3}$ & 20 & $>1: 20$ \\
2 & $\mathrm{SnCl}_{4}{ }^{\mathrm{bb}]}$ & 100 & $>20: 1$ \\
3 & $\mathrm{AuCl}_{3}$ & 50 & $>20: 1$ \\
4 & $\mathrm{Cu}(\mathrm{OTf})_{2}$ & 10 & n.d. \\
5 & $\mathrm{In}(\mathrm{OTf})_{3}$ & 33 & $5: 1$ \\
6 & $\mathrm{Sc}(\mathrm{OTf})_{3}$ & 25 & $>20: 1$ \\
7 & $\mathrm{Sn}(\mathrm{OTf})_{2}$ & 13 & - \\
8 & $\mathrm{Hf}(\mathrm{OTf})_{4}$ & decomp.
\end{tabular}

[a] No reaction with: $\mathrm{Zn}(\mathrm{OTf})_{2}, \mathrm{TiCl}_{4}, \mathrm{AuCl}, \mathrm{EtAlCl}, \mathrm{Me}_{2} \mathrm{AlCl}, \mathrm{CeCl}_{3}$. [b] Performed at -78 ${ }^{\circ} \mathrm{C}$.

\subsubsection{Reactions with cyclohexanone}

All the reactions were carried out under nitrogen in glass vials equipped with rubber septa and Teflon-coated stir bars. The Lewis acid ( $4 \mu \mathrm{mol}, 20 \mathrm{~mol} \%$ ) was added to the vial in the glove box, followed by a solution of aminocyclopropane 1a $(20 \mu \mathrm{mol}, 6.6 \mathrm{mg}, 1$ equiv.) and cyclohexanone $2 \mathbf{i}(30 \mu \mathrm{mol}, 3.1 \mu \mathrm{L}, 1.5$ equiv.) in anhydrous dichloromethane ( $0.1 \mathrm{M}, 0.2$ $\mathrm{mL}$ ) was added under nitrogen. The mixture was stirred for $90 \mathrm{~min}$ at the indicated 
temperature, and then it was diluted with dichloromethane $(0.5 \mathrm{~mL})$ and flushed through a short plug of silica gel. The solvent was removed in vacuo, then a ${ }^{1} \mathrm{H}-\mathrm{NMR}$ sample was prepared by dissolving the crude mixture in $\mathrm{CDCl}_{3}(0.7 \mathrm{~mL})$ and a standard hexamethyldisiloxane solution $(0.01 \mathrm{M}, 0.111 \mathrm{~mL})$ was added. The ${ }^{1} \mathrm{H}-\mathrm{NMR}$ yield was calculated according to the following calibration curve.

\section{${ }^{1} \mathrm{H}-\mathrm{NMR}$ calibration curve}

Hexamethyldisiloxane $(4.3 \mu \mathrm{L}, 0.02 \mathrm{mmol})$ was dissolved in $\mathrm{CDCl}_{3}(2.0 \mathrm{~mL})$, to give a 0.01 M standard solution. Compound 3aj (6.6 mg, $15 \mu \mathrm{mol})$ was dissolved in $\mathrm{CDCl}_{3}(0.7 \mathrm{~mL})$, then the following volumes of standard $0.01 \mathrm{~m}$ solution were added: $88 \mu \mathrm{L}$ for sample A $(0.88$ $\mu \mathrm{mol}) ; 22 \mu \mathrm{L}$ for sample $\mathrm{B}(0.22 \mu \mathrm{mol}) ; 37 \mu \mathrm{L}$ for sample $\mathrm{C}(0.37 \mu \mathrm{mol}) ; 74 \mu \mathrm{L}$ for sample $\mathrm{D}$ $(0.74 \mu \mathrm{mol}) ; 222 \mu \mathrm{L}$ for sample $\mathrm{E}(2.22 \mu \mathrm{mol})$.

${ }^{1} \mathrm{H}$ NMR spectra were acquired for solution A-E, and the ratios between the integrals of the signal at $\delta 6.39(\mathrm{dd}, 1 \mathrm{H}, J=9.4,6.6 \mathrm{~Hz}, C H \mathrm{NPhth})$ of 3aj and the signal at $\delta 0.06(\mathrm{~s}, 1 \mathrm{H}$, TMS) of hexamethyldisiloxane were determined. These experimental ratios were plotted vs. the ratios mmol 3ai / mmol hexamethyldisiloxane to give the calibration graph.

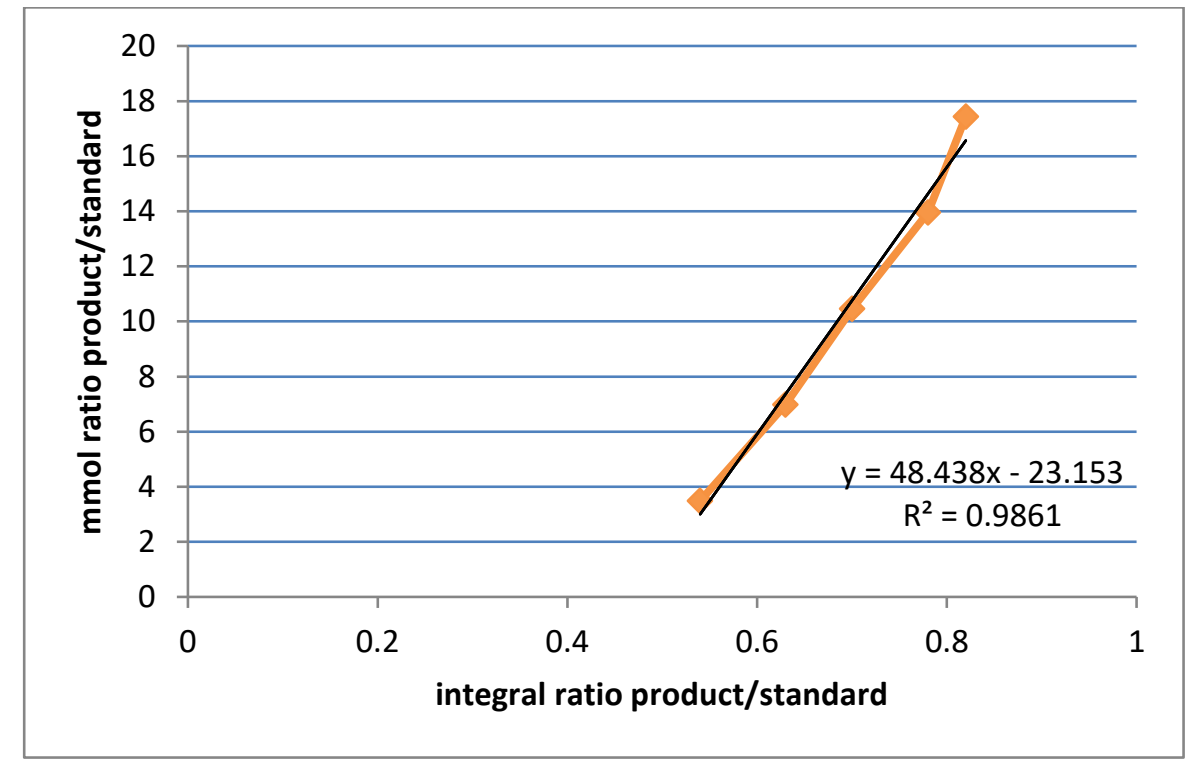

Table S2. Screening of Lewis Acids in the reaction with cyclohexanone. ${ }^{[a]}$

\begin{tabular}{ccc}
\hline entry & Lewis acid & yield $(\%)$ \\
\hline 1 & $\mathrm{FeCl}_{3}-\mathrm{Al}_{2} \mathrm{O}_{3}$ & 100 \\
2 & $\mathrm{SnCl}_{4}{ }^{[\mathrm{b}]}$ & 100 \\
3 & $\mathrm{InCl}_{3}$ & 80 \\
4 & $\mathrm{AuCl}$ & 60
\end{tabular}




\begin{tabular}{ccc}
5 & $\mathrm{Cu}(\mathrm{OTf})_{2}$ & 40 \\
6 & $\mathrm{In}(\mathrm{OTf})_{3}$ & 80 \\
7 & $\mathrm{Sc}(\mathrm{OTf})_{3}$ & 100 \\
8 & $\mathrm{Sn}(\mathrm{OTf})_{2}$ & 70 \\
9 & $\mathrm{Hf}(\mathrm{OTf})_{4}$ & 90 \\
\hline
\end{tabular}

[a] No reaction with: $\mathrm{Zn}(\mathrm{OTf})_{2}, \mathrm{AgOTf}, \mathrm{MgI}_{2}$. [b] Performed at $-78{ }^{\circ} \mathrm{C}$.

\subsection{Standard procedure for testing the dependence of d.r. on temperature and $\mathrm{SnCl}_{4}$ loading (Table 2)}

In a two-neck flask equipped with a nitrogen inlet, aminocyclopropane $1 \mathbf{a}(0.20 \mathrm{mmol}, 66 \mathrm{mg}$, 1 equiv) and acetophenone $2 \mathrm{a}(0.30 \mathrm{mmol}, 35 \mu \mathrm{L}, 1.5$ equiv) were dissolved in anhydrous dichloromethane $(2 \mathrm{~mL})$ at $-78{ }^{\circ} \mathrm{C}$. After $5 \mathrm{~min}, \mathrm{SnCl}_{4}(5-20 \mathrm{~mol} \%, 0.01-0.04 \mathrm{mmol}, 23-92$ $\mu \mathrm{L}$ of $0.43 \mathrm{M}$ solution in dichloromethane $)^{[3]}$ was added. The mixture was stirred under nitrogen at $-78{ }^{\circ} \mathrm{C}$ for $90 \mathrm{~min}$, then it was quenched by the addition of triethylamine $(0.2 \mathrm{~mL})$ and subsequently flushed through a short plug of silica gel, eluting with EtOAc $(5 \mathrm{~mL})$. The solvent was removed in vacuo, affording the crude reaction mixture, which was submitted to ${ }^{1} \mathrm{H}$ NMR analysis for d.r. determination.

\subsection{Standard procedure for the $\mathrm{SnCl}_{4}$-catalysed [3+2] annulation of aminocyclopropanes with ketones}

In a two-neck flask equipped with a nitrogen inlet, aminocyclopropane 1a-b $(0.20 \mathrm{mmol}, 60$ $66 \mathbf{m g}, 1$ equiv.) and ketone $\mathbf{2} \mathbf{a}-\mathbf{m}$ (1.5 equiv for $\mathbf{2 a - 1 ,} 3$ equiv for $\mathbf{2} \mathbf{m}$ ) were dissolved in anhydrous dichloromethane $(2 \mathrm{~mL})$ at $-78{ }^{\circ} \mathrm{C}$. After $5 \mathrm{~min}, \mathrm{SnCl}_{4}(5 \mathrm{~mol} \%, 0.01 \mathrm{mmol}, 23$ $\mu \mathrm{L}$ of $0.43 \mathrm{M}$ solution in dichloromethane) was added. The mixture was stirred under nitrogen at $-78{ }^{\circ} \mathrm{C}$ for $90 \mathrm{~min}$, then it was quenched by the addition of triethylamine $(0.2 \mathrm{~mL})$ and subsequently flushed through a short plug of silica gel, eluting with EtOAc $(5 \mathrm{~mL})$. The solvent was removed in vacuo, affording the crude reaction mixture, which was submitted to ${ }^{1} \mathrm{H}$ NMR analysis to determine the d.r. before purification via flash chromatography $\left(\mathrm{SiO}_{2}\right.$, $8 / 2$ to $1 / 1$ (n-hexane: AcOEt)).

[3] Prepared by diluting $100 \mu \mathrm{L}$ of $\mathrm{SnCl}_{4}(0.86 \mathrm{mmol})$ in $2 \mathrm{~mL}$ of anhydrous dichloromethane. 


\section{Scope of the reaction}

Diethyl 5-(1,3-dioxoisoindolin-2-yl)-2-methyl-2-phenyldihydrofuran-3,3(2H)dicarboxylate (3aa)

Flash chromatography afforded the title compound (90 mg, $0.20 \mathrm{mmol}, 99 \%$ yield) as a colorless solid, as a single diastereoisomer (d.r. > 20:1).

$\mathbf{R}_{\mathbf{f}} 0.58$ ( $n$-hex/EtOAc 6/4);

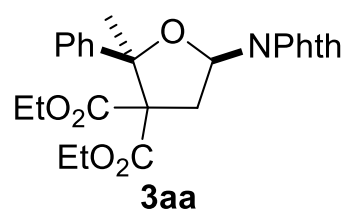

Mp 88-90 ${ }^{\circ} \mathrm{C}$;

${ }^{1} \mathbf{H}$ NMR $\left(400 \mathrm{MHz}, \mathrm{CDCl}_{3}\right) \delta 7.93(\mathrm{dd}, 2 \mathrm{H}, J=5.5,3.0 \mathrm{~Hz}, \mathrm{Phth})$, $7.78(\mathrm{dd}, 2 \mathrm{H}, J=5.5,3.0 \mathrm{~Hz}, \mathrm{Phth}), 7.69(\mathrm{~d}, 2 \mathrm{H}, J=7.2 \mathrm{~Hz}, \mathrm{Ph})$, 7.35-7.20 (m, $3 \mathrm{H}, \mathrm{Ph}), 6.31$ (dd, $1 \mathrm{H}, J=8.2,7.0 \mathrm{~Hz}, C H \mathrm{NPhth}), 4.36$ (q, $2 \mathrm{H}, J=7.1 \mathrm{~Hz}, \mathrm{OCH}_{2} \mathrm{CH}_{3}$ ), 3.92-3.69 (m, $3 \mathrm{H}, \mathrm{OCH}_{2} \mathrm{CH}_{3}+\mathrm{CH}_{2} \mathrm{CHNPhth}$ ), 3.13 (dd, 1 $\left.\mathrm{H}, J=13.9,7.0 \mathrm{~Hz}, \mathrm{CH}_{2} \mathrm{CHNPhth}\right), 1.80\left(\mathrm{~s}, 3 \mathrm{H}, \mathrm{CH}_{3}\right), 1.39$ (t, $\left.3 \mathrm{H}, J=7.1 \mathrm{~Hz}, \mathrm{OCH}_{2} \mathrm{CH}_{3}\right)$, 0.97 (t, $\left.3 \mathrm{H}, J=7.1 \mathrm{~Hz}, \mathrm{OCH}_{2} \mathrm{CH}_{3}\right)$;

${ }^{13}$ C NMR (101 MHz, $\left.\mathrm{CDCl}_{3}\right) \delta 165.2,164.5,163.4,140.3,131.8,129.3,125.2,124.8,124.1$, $121.5,85.9,77.8,67.9,62.7,61.9,37.3,28.2,16.6,16.2$;

IR 3060 (w), 2984 (w), 2940 (w), 2905 (w), 1782 (m), 1721 (s), 1612 (w), 1469 (w), 1447 (w), 1368 (s), 1301 (m), 1256 (m), 1219 (m), 1193 (w), 1138 (m), 1112 (m), 1095 (m), 1065 (m), 1031 (m), 1022 (m), $981(\mathrm{w}), 908$ (m), 870 (w), 767 (m), $719(\mathrm{~s}), 702(\mathrm{~m}), 657$ (w);

HRMS (ESI) calcd for $\mathrm{C}_{25} \mathrm{H}_{25} \mathrm{NNaO}_{7}^{+}[\mathrm{M}+\mathrm{Na}]^{+}$474.1523; found 474.1528.

HPLC analysis: Chiracel IA: 85:15 (hexane: $i$-PrOH), flow $1.0 \mathrm{~mL} / \mathrm{min} . \mathrm{t}_{1}=8.9 \mathrm{~min},[\alpha]_{\mathrm{D}}^{25}-$ 55 (er: 97.5:2.5, $c$ 0.5, $\left.\mathrm{CHCl}_{3}\right), \mathrm{t}_{2}=13.0 \mathrm{~min}$.

\section{Diethyl 5-(1,3-dioxoisoindolin-2-yl)-2-methyl-2-phenyldihydrofuran-3,3(2H)-}

dicarboxylate (epi-3aa)

Flash chromatography afforded the title compound (19 $\mathrm{mg}, 0.04 \mathrm{mmol}, 21 \%$ yield) as a colorless solid, as a single diastereoisomer (d.r. > 20:1).

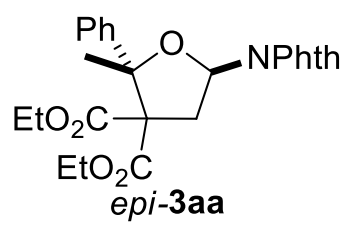

$\mathbf{R}_{\mathbf{f}} 0.67$ ( $n$-hex/EtOAc 6/4);

Mp 118-119 ${ }^{\circ} \mathrm{C}$;

${ }^{1} \mathbf{H}$ NMR $\left(400 \mathrm{MHz}, \mathrm{CDCl}_{3}\right) \delta 7.92(\mathrm{dd}, 2 \mathrm{H}, J=5.5,3.1 \mathrm{~Hz}, \mathrm{Phth})$, 7.71-7.75 (m, $3 \mathrm{H}$, Phth + Ar), 7.34-7.19 (m, 4 H, Ph), $6.72(\mathrm{dd}, 1 \mathrm{H}, J$ = 9.8, $6.2 \mathrm{~Hz}, C H \mathrm{NPhth}), 4.40-4.26\left(\mathrm{~m}, 2 \mathrm{H}, \mathrm{OCH}_{2} \mathrm{CH}_{3}\right), 4.02(\mathrm{dd}, 1 \mathrm{H}, J=13.3,9.8 \mathrm{~Hz}$, $\left.\mathrm{CH}_{2} \mathrm{CHNPhth}\right), 3.71\left(\mathrm{dq}, 1 \mathrm{H}, \mathrm{J}=10.7,7.2 \mathrm{~Hz}, \mathrm{OCH}_{2} \mathrm{CH}_{3}\right), 3.58(\mathrm{dq}, 1 \mathrm{H}, J=10.7,7.2 \mathrm{~Hz}$, $\mathrm{OCH}_{2} \mathrm{CH}_{3}$ ), 2.70 (dd, $1 \mathrm{H}, J=13.3,6.2 \mathrm{~Hz}, \mathrm{CH}_{2} \mathrm{CHNPhth}$ ), 2.00 (s, 3H, $\left.\mathrm{CH}_{3}\right), 1.36$ (t, $3 \mathrm{H}, J$ $\left.=7.2 \mathrm{~Hz}, \mathrm{OCH}_{2} \mathrm{CH}_{3}\right), 0.83$ (t, $3 \mathrm{H}, J=7.2 \mathrm{~Hz}, \mathrm{OCH}_{2} \mathrm{CH}_{3}$ ); 
${ }^{13} \mathrm{C}$ NMR $\left(101 \mathrm{MHz}, \mathrm{CDCl}_{3}\right) \delta 169.5,168.2,167.9,143.3,134.4,131.9,127.6,127.2,126.2$, $123.6,87.8,79.6,68.8,61.7,34.3,28.6,14.0,13.3 ;^{[4]}$

IR 2983 (w), 2940 (w), 1781 (w), 1720 (s), 1609 (w), 1495 (w), 1469 (w), 1447 (w), 1369 (m), 1332 (w), 1300 (w), 1275 (m), 1250 (m), 1217 (w), 1131 (m), 1115 (w), 1090 (m), 1066 (m), 1033 (w), 1018 (w), 990 (w), 909 (w), 868 (w), 767 (m), 730 (m), 704 (m), 659 (w);

HRMS (ESI) calcd for $\mathrm{C}_{25} \mathrm{H}_{25} \mathrm{NNaO}_{7}^{+}[\mathrm{M}+\mathrm{Na}]^{+} 474.1523$; found 474.1527 .

\section{Dimethyl 5-(1,3-dioxoisoindolin-2-yl)-2-methyl-2-phenyldihydrofuran-3,3(2H)- dicarboxylate (3ba)}

Flash chromatography afforded the title compound (81 $\mathrm{mg}, 0.19 \mathrm{mmol}, 96 \%$ yield) as a colorless solid, as a single diastereoisomer (d.r. > 20:1).

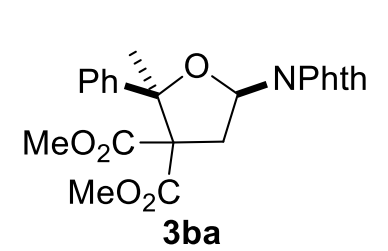

$\mathbf{R}_{\mathbf{f}} 0.48(n$-hex/EtOAc 6/4);

Mp $148-150{ }^{\circ} \mathrm{C}$;

${ }^{1}$ H NMR (400 MHz, $\left.\mathrm{CDCl}_{3}\right) \delta 7.93(\mathrm{dd}, 2 \mathrm{H}, J=5.4,3.0 \mathrm{~Hz}, \mathrm{Phth})$, 7.79 (dd, $2 \mathrm{H}, J=5.4,3.0 \mathrm{~Hz}$, Phth), 7.65 (d, $2 \mathrm{H}, J=7.3 \mathrm{~Hz}, \mathrm{Ph})$, $7.33(\mathrm{t}, 1 \mathrm{H}, J=7.3 \mathrm{~Hz}, \mathrm{Ph}), 7.29-7.22(\mathrm{~m}, 2 \mathrm{H}, \mathrm{Ph}$ ), 6.31 (pseudo t, $1 \mathrm{H}, J=7.2 \mathrm{~Hz}$, CHNPhth), 3.90 (s, $3 \mathrm{H}, \mathrm{OCH}_{3}$ ), 3.93-3.83 (m, $1 \mathrm{H}, \mathrm{CH}_{2} \mathrm{CHNPhth}$ ), 3.38 (s, $3 \mathrm{H}, \mathrm{OCH}_{3}$ ), 3.15 (dd, $1 \mathrm{H}, J=13.9,7.2 \mathrm{~Hz}, \mathrm{CH}_{2} \mathrm{CHNPhth}$ ), 1.79 (s, 3H, $\mathrm{CH}_{3}$ );

${ }^{13}$ C NMR (101 MHz, $\left.\mathrm{CDCl}_{3}\right) \delta 169.7,168.9,167.5,143.0,134.4,131.8,127.5,127.2,126.3$, 123.7, 86.6, 77.9, 67.5, 53.1, 52.3, 35.6, 25.9;

IR 2955 (w), 1783 (w), 1724 (m), 1436 (w), 1375 (m), 1259 (w), 1140 (w), 1068 (w), 907 (s), $730(\mathrm{~s}), 703(\mathrm{~m}), 651(\mathrm{~m}), 639(\mathrm{w})$;

HRMS (ESI) calcd for $\mathrm{C}_{23} \mathrm{H}_{21} \mathrm{NNaO}_{7}{ }^{+}[\mathrm{M}+\mathrm{Na}]^{+}$446.1210; found 446.1232.

\section{Dimethyl 5-(1,3-dioxoisoindolin-2-yl)-2-methyl-2-(naphthalen-1-yl)dihydrofuran-}

\section{3,3(2H)-dicarboxylate (3bb)}

Flash chromatography afforded the title compound (75 $\mathrm{mg}, 0.16 \mathrm{mmol}, 79 \%$ yield) as a colorless solid, as a single diastereoisomer (d.r. > 20:1).

Rf 0.52 (n-hex/EtOAc 6/4);

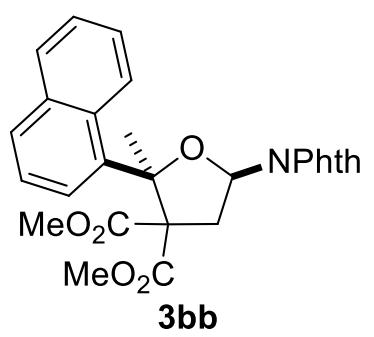

[4] Two carbons $\left(\mathrm{OCH}_{2} \mathrm{CH}_{3}\right)$ are overlapping.

$$
3 \mathrm{bb}
$$

Mp 211-213 ${ }^{\circ} \mathrm{C}$;

${ }^{1} \mathbf{H}$ NMR $\left(400 \mathrm{MHz}, \mathrm{CDCl}_{3}\right) \delta 8.67(\mathrm{~d}, 1 \mathrm{H}, J=8.5 \mathrm{~Hz}$, Naphth), 7.97 (d, $1 \mathrm{H}, J=7.2 \mathrm{~Hz}$, Naphth), 7.91 (dd, $2 \mathrm{H}, J=5.4,3.0 \mathrm{~Hz}, \mathrm{Phth}$ ), 7.83-7.70 (m, 4 H, Naphth + Phth), 7.50-7.35 (m, 3 H, Naphth) 6.33 
(dd, $1 \mathrm{H}, J=8.4,6.8 \mathrm{~Hz}, C H \mathrm{NPhth}), 3.98$ (s, $3 \mathrm{H}, \mathrm{OCH}_{3}$ ), 4.05-3.93 (m, $1 \mathrm{H}, \mathrm{CH}_{2} \mathrm{CHNPhth}$ ), 3.24 (dd, $\left.1 \mathrm{H}, J=13.6,6.8 \mathrm{~Hz}, \mathrm{CH}_{2} \mathrm{CHNPhth}\right), 3.18$ (s, $\left.3 \mathrm{H}, \mathrm{OCH}_{3}\right), 2.00$ (s, 3H, $\mathrm{CH}_{3}$ );

${ }^{13} \mathrm{C}$ NMR $\left(101 \mathrm{MHz}, \mathrm{CDCl}_{3}\right) \delta 170.1,170.0,167.5,139.0,134.4,131.7,130.6,128.9,128.5$, $126.7,125.3,124.8,124.7,123.7,89.1,77.6,68.1,53.2,52.3,36.1,27.3 ;^{[5]}$

IR 3050 (w), 2952 (w), 1783 (w), 1721 (s), 1468 (w), 1435 (w), 1371 (m), 1301 (w), 1259 (m), 1222 (m), 1138 (m), 1108 (w), 1088 (m), 1059 (m), 1032 (m), 1031 (m), 1005 (w), 994 (w), $971(\mathrm{w}), 910(\mathrm{~m}), 871(\mathrm{w}), 807(\mathrm{~m}), 780(\mathrm{~m}), 724(\mathrm{~s}), 684(\mathrm{w}), 672(\mathrm{~m}), 649(\mathrm{~m}), 627$ (w), $613(\mathrm{w})$;

HRMS (ESI) calcd for $\mathrm{C}_{27} \mathrm{H}_{23} \mathrm{NNaO}_{7}{ }^{+}[\mathrm{M}+\mathrm{Na}]^{+}$496.1367; found 496.1380 .

\section{Dimethyl 5-(1,3-dioxoisoindolin-2-yl)-2-(4-methoxyphenyl)-2-methyldihydrofuran- \\ 3,3(2H)-dicarboxylate (3ac)}

Flash chromatography afforded the title compound (82 $\mathrm{mg}, 0.18 \mathrm{mmol}, 90 \%$ yield) as a colorless solid, as an inseparable mixture of diastereoisomers; d.r. = 16:1 determined by

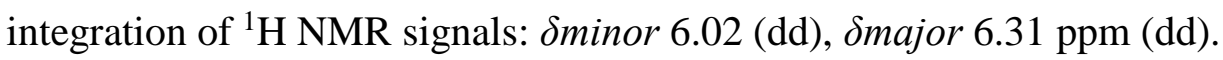

Recrystallization from $i \mathrm{PrOH}$ afforded analytically pure cis isomer (d.r. > 20:1).

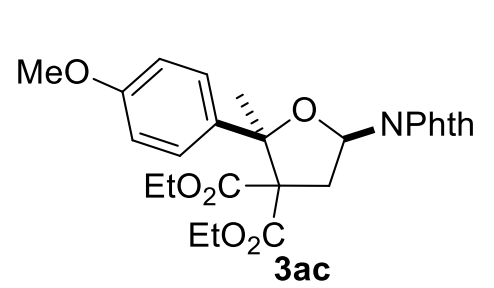

$$
\mathbf{R}_{\mathbf{f}} 0.39 \text { (n-hex/EtOAc 6/4); }
$$

Mp $132-134{ }^{\circ} \mathrm{C}$;

${ }^{1} \mathbf{H}$ NMR $\left(400 \mathrm{MHz}, \mathrm{CDCl}_{3}\right) \delta 7.92(\mathrm{dd}, 2 \mathrm{H}, J=5.5,3.0 \mathrm{~Hz}$, Phth), 7.78 (dd, 2 H, $J=5.5,3.0 \mathrm{~Hz}$, Phth), 7.59 (d, $2 \mathrm{H}, J=9.0$ $\mathrm{Hz}, \mathrm{Ar}), 6.86$ (d, $2 \mathrm{H}, J=9.0 \mathrm{~Hz}, \mathrm{Ar}), 6.31$ (dd, $1 \mathrm{H}, J=8.0,6.9 \mathrm{~Hz}, C H \mathrm{NPhth}), 3.91$ (dd, 1 $\left.\mathrm{H}, J=13.8,8.0 \mathrm{~Hz}, \mathrm{CH}_{2} \mathrm{CHNPhth}\right), 3.88$ (s, $\left.3 \mathrm{H}, \mathrm{OCH}_{3}\right), 3.80$ (s, $\left.3 \mathrm{H}, \mathrm{OCH}_{3}\right), 3.41$ (s, $3 \mathrm{H}$, $\left.\mathrm{OCH}_{3}\right), 3.06$ (dd, $\left.1 \mathrm{H}, J=13.8,6.9 \mathrm{~Hz}, \mathrm{CH}_{2} \mathrm{CHNPhth}\right), 1.79$ (s, 3H, CH 3 );

${ }^{13}$ C NMR (101 MHz, $\left.\mathrm{CDCl}_{3}\right) \delta 169.8,168.8,167.5,158.7,135.1,134.4,131.8,127.7,123.7$, $112.8,86.5,78.0,67.5,55.2,53.0,52.3,35.4,25.8$;

IR 2998 (w), 2954 (w), 2839 (w), 1782 (m), 1721 (s), 1612 (w), 1515 (m), 1467 (w), 1435 (m), 1373 (s), 1251 (s), 1183 (m), 1139 (m), 1078 (m), 1033 (m), 914 (m), 832 (m), 724 (s), $637(\mathrm{~m})$;

HRMS (ESI) calcd for $\mathrm{C}_{24} \mathrm{H}_{24} \mathrm{NO}_{8}{ }^{+}[\mathrm{M}+\mathrm{H}]^{+}$454.1496; found 454.1493.

Dimethyl 2-(benzofuran-2-yl)-5-(1,3-dioxoisoindolin-2-yl)-2-methyldihydrofuran3,3(2H)-dicarboxylate (3bd)

[5] Two C of the naphthyl group are not resolved. 
Flash chromatography afforded the title compound ( $87 \mathrm{mg}, 0.19 \mathrm{mmol}, 95 \%$ yield) as a colorless solid, as an inseparable mixture of diastereoisomers; d.r. $=4: 1$ determined by

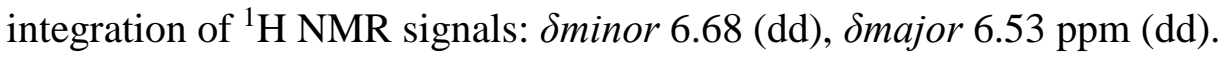

Recrystallization from $i \mathrm{PrOH}$ gave increased d.r. in favour of the $c$ is isomer (14:1).

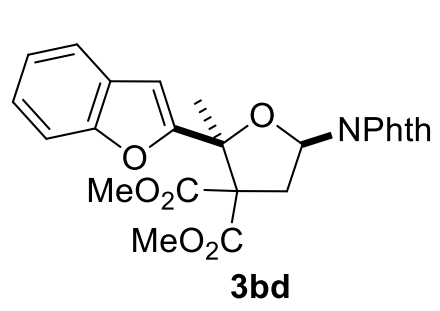

$\mathbf{R}_{\mathbf{f}} 0.46$ (n-hex/EtOAc 6/4);

Mp $90-92{ }^{\circ} \mathrm{C}$;

${ }^{1} \mathbf{H}$ NMR (cis isomer, $\left.400 \mathrm{MHz}, \mathrm{CDCl}_{3}\right) \delta 7.87(\mathrm{dd}, 2 \mathrm{H}, J=5.4$, $3.0 \mathrm{~Hz}$, Phth), 7.73 (dd, $2 \mathrm{H}, J=5.4,3.0 \mathrm{~Hz}$, Phth), 7.55 (d, $1 \mathrm{H}, J$ $=7.8 \mathrm{~Hz}, \mathrm{Ar}), 7.49$ (d, $1 \mathrm{H}, J=7.8 \mathrm{~Hz}, \mathrm{Ar}), 7.27$ (t, $1 \mathrm{H}, J=7.8$ $\mathrm{Hz}, \mathrm{Ar}), 7.18$ (t, $1 \mathrm{H}, J=7.8 \mathrm{~Hz}, \mathrm{Ar}), 6.90$ (s, $1 \mathrm{H}, \mathrm{Ar}), 6.53$ (dd, $1 \mathrm{H}, J=9.8,5.8 \mathrm{~Hz}$, CHNPhth), 4.59 (dd, $1 \mathrm{H}, J=13.4,9.8 \mathrm{~Hz}, \mathrm{CH}_{2} \mathrm{CHNPhth}$ ), 3.90 (s, $\left.3 \mathrm{H}, \mathrm{OCH}_{3}\right), 3.54$ (s, $3 \mathrm{H}$, $\left.\mathrm{OCH}_{3}\right), 2.79$ (dd, $\left.1 \mathrm{H}, J=13.4,5.8 \mathrm{~Hz}, \mathrm{CH}_{2} \mathrm{CHNPhth}\right), 1.94$ (s, 3H, $\mathrm{CH}_{3}$ );

${ }^{13} \mathrm{C}$ NMR (cis isomer, $101 \mathrm{MHz}, \mathrm{CDCl}_{3}$ ) $\delta 169.7,168.0,167.7,158.2,154.4,134.3,131.7$, 128.1, 124.3, 123.6, 122.7, 121.3, 111.2, 104.3, 83.0, 80.3, 67.0, 53.2, 52.7, 34.0, 22.9;

IR 2954 (w), 1782 (w), 1720 (s), 1454 (w), 1435 (w), 1367 (m), 1327 (w), 1256 (s), 1217 (m), 1175 (w), 1140 (m), 1120 (m), 1072 (m), 1012 (w), 992 (m), 972 (m), 944 (w), 921 (w), $887(\mathrm{w}), 872(\mathrm{~m}), 813(\mathrm{w})$;

HRMS (ESI) calcd for $\mathrm{C}_{25} \mathrm{H}_{21} \mathrm{NNaO}_{8}{ }^{+}[\mathrm{M}+\mathrm{Na}]^{+} 486.1159$; found 486.1153 .

Dimethyl 5-(1,3-dioxoisoindolin-2-yl)-2-(4-fluorophenyl)-2-methyldihydrofuran-3,3(2H)dicarboxylate (3be)

Flash chromatography afforded the title compound (82 $\mathrm{mg}, 0.18 \mathrm{mmol}, 93 \%$ yield) as a colorless solid, as a single diastereoisomer (d.r. > 20:1).

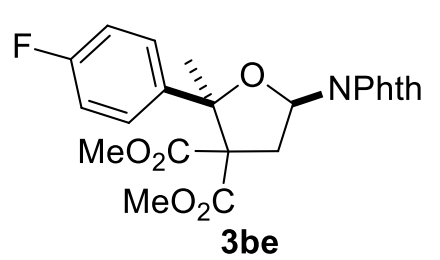

Rf 0.48 ( $n$-hex/EtOAc 6/4);

Mp $152-153{ }^{\circ} \mathrm{C}$;

${ }^{1} \mathbf{H}$ NMR $\left(400 \mathrm{MHz}, \mathrm{CDCl}_{3}\right) \delta 7.93(\mathrm{dd}, 2 \mathrm{H}, J=5.5,3.0 \mathrm{~Hz}$, Phth), 7.79 (dd, $2 \mathrm{H}, J=5.5,3.0 \mathrm{~Hz}$, Phth), 7.64 (dd, $2 \mathrm{H}, J=8.8$, $5.4 \mathrm{~Hz}, \mathrm{Ar}$ ), 7.01 (pseudo t, $2 \mathrm{H}, J=8.8 \mathrm{~Hz}, \mathrm{Ar}$ ), 6.30 (pseudo t, $1 \mathrm{H}, J=7.5 \mathrm{~Hz}, C H \mathrm{NPhth}$ ), $3.90\left(\mathrm{~s}, 3 \mathrm{H}, \mathrm{OCH}_{3}\right), 3.85$ (dd, $\left.1 \mathrm{H}, J=14.0,7.7 \mathrm{~Hz}, \mathrm{CH}_{2} \mathrm{CHNPhth}\right), 3.44$ (s, $3 \mathrm{H}, \mathrm{OCH}_{3}$ ), 3.16 (dd, $1 \mathrm{H}, J=14.0,7.3 \mathrm{~Hz}, \mathrm{CH}_{2} \mathrm{CHNPhth}$ ), 1.76 (s, 3H, $\mathrm{CH}_{3}$ );

${ }^{13}$ C NMR $\left(101 \mathrm{MHz}, \mathrm{CDCl}_{3}\right) \delta 169.5,168.8,167.5,162.0\left(\mathrm{~d}, J_{C-F}=246 \mathrm{~Hz}\right), 138.7\left(\mathrm{~d}, J_{C-F}\right.$ para $=3 \mathrm{~Hz}), 134.5,131.7,128.1\left(\mathrm{~d}, J_{\text {C-F meta }}=8 \mathrm{~Hz}\right), 123.8,114.2\left(\mathrm{~d}, J_{\text {C-F ortho }}=21 \mathrm{~Hz}\right), 86.2$, 77.8, 67.3, 53.1, 52.4, 35.6, 26.0; 
IR $2954(w), 1723(\mathrm{~s}), 1605$ (w), 1511 (m), 1458 (w), 1436 (w), 1374 (s), 1275 (m), 1139 (m), $1078(\mathrm{~m}), 1019(\mathrm{w}), 972(\mathrm{w}), 913$ (m), 870 (w), 839 (w), 731 (m), 722 (s);

HRMS (ESI) calcd for $\mathrm{C}_{23} \mathrm{H}_{20} \mathrm{FNNaO}_{7}^{+}[\mathrm{M}+\mathrm{Na}]^{+} 464.1116$; found 464.1139.

\section{Dimethyl 5-(1,3-dioxoisoindolin-2-yl)-2-(4-(methoxycarbonyl)phenyl)-2-} methyldihydrofuran-3,3(2H)-dicarboxylate (3bf)

Flash chromatography afforded the title compound (96 mg, $0.20 \mathrm{mmol}, 99 \%$ yield) as a colorless solid, as as a single diastereoisomer (d.r. > 20:1).

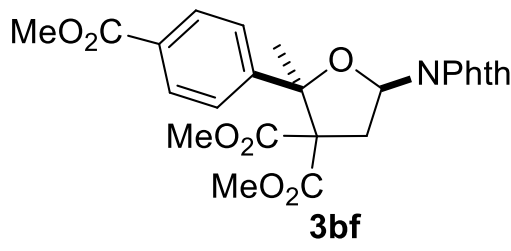

$\mathbf{R}_{\mathbf{f}} 0.25$ (n-hex/EtOAc 6/4);

Mp $151-152{ }^{\circ} \mathrm{C}$;

${ }^{1} \mathbf{H}$ NMR $\left(400 \mathrm{MHz}, \mathrm{CDCl}_{3}\right) \delta 7.99(\mathrm{~d}, 2 \mathrm{H}, J=8.6 \mathrm{~Hz}, \mathrm{Ar})$, 7.93 (dd, $2 \mathrm{H}, J=5.5,3.0 \mathrm{~Hz}$, Phth), 7.79 (dd, $2 \mathrm{H}, J=5.5$,

$3.0 \mathrm{~Hz}$, Phth), 7.71 (d, $2 \mathrm{H}, J=8.6 \mathrm{~Hz}$, Ar), 6.29 (pseudo t, $1 \mathrm{H}, J=7.5 \mathrm{~Hz}, C H \mathrm{NPhth}$ ), 3.92 (s, $3 \mathrm{H}, \mathrm{OCH}_{3}$ ), 3.91 (s, $3 \mathrm{H}, \mathrm{OCH}_{3}$ ), 3.79 (dd, $1 \mathrm{H}, J=14.1,7.3 \mathrm{~Hz}, \mathrm{CH}_{2} \mathrm{CHNPhth}$ ), 3.44 (s, $3 \mathrm{H}, \mathrm{OCH}_{3}$ ), 3.28 (dd, $\left.1 \mathrm{H}, J=14.1,7.7 \mathrm{~Hz}, \mathrm{CH}_{2} \mathrm{CHNPhth}\right), 1.73$ (s, $3 \mathrm{H}, \mathrm{CH}_{3}$ );

${ }^{13} \mathrm{C}$ NMR $\left(101 \mathrm{MHz}, \mathrm{CDCl}_{3}\right) \delta 169.3,168.7,167.4,167.0,148.2,134.6,131.7,128.8,128.0$, $126.1,123.8,86.3,77.4,67.2,53.2,52.4,52.0,35.8,25.9$;

IR 2954 (w), 1717 (s), 1613 (w), 1436 (w), 1371 (m), 1277 (s), 1255 (s), 1193 (m), 1135 (m), $1114(\mathrm{~m}), 1074(\mathrm{~m}), 969(\mathrm{w}), 929(\mathrm{w}), 899(\mathrm{w}), 871(\mathrm{w}), 842(\mathrm{w})$;

HRMS (ESI) calcd for $\mathrm{C}_{25} \mathrm{H}_{23} \mathrm{NNaO}_{9}{ }^{+}[\mathrm{M}+\mathrm{Na}]^{+}$504.1265; found 504.1260.

Diethyl 5-(1,3-dioxoisoindolin-2-yl)-2-ethyl-2-phenyldihydrofuran-3,3(2H)-dicarboxylate (3ag)

Flash chromatography afforded the title compound $(88 \mathrm{mg}, 0.19 \mathrm{mmol}, 95 \%$ yield) as a colorless solid, as a single diastereoisomer (d.r. > 20:1).

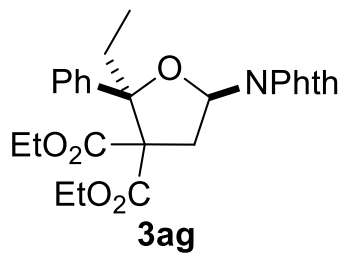

7.37-7.17 (m, $3 \mathrm{H}, \mathrm{Ph}$ ), 6.10 (pseudo t, $1 \mathrm{H}, J=7.6 \mathrm{~Hz}, C H \mathrm{NPhth}$ ), 4.37 (q, $2 \mathrm{H}, J=7.1 \mathrm{~Hz}$, $\mathrm{OCH}_{2} \mathrm{CH}_{3}$ ), 3.90-3.81 (m, $2 \mathrm{H}, \mathrm{OCH}_{2} \mathrm{CH}_{3}$ ), 3.77 (dd, $1 \mathrm{H}, J=14.0,7.4 \mathrm{~Hz}, \mathrm{CH}_{2} \mathrm{CHNPhth}$ ), 3.30 (dd, $1 \mathrm{H}, J=14.0,7.8 \mathrm{~Hz}, \mathrm{CH}_{2} \mathrm{CHNPhth}$ ), 2.19-1.99 (m, $2 \mathrm{H}, \mathrm{CH}_{2} \mathrm{CH}_{3}$ ), 1.39 (t, $3 \mathrm{H}, J=$ $7.1 \mathrm{~Hz}, \mathrm{OCH}_{2} \mathrm{CH}_{3}$ ), 0.96 (t, $\left.3 \mathrm{H}, J=7.1 \mathrm{~Hz}, \mathrm{OCH}_{2} \mathrm{CH}_{3}\right), 0.71$ (t, $3 \mathrm{H}, J=7.2 \mathrm{~Hz}, \mathrm{CH}_{2} \mathrm{CH}_{3}$ ); ${ }^{13}$ C NMR (101 MHz, $\left.\mathrm{CDCl}_{3}\right) \delta 169.0,168.9,167.4,140.2,134.4,131.8,127.2,126.8,126.7$, $123.7,88.8,76.7,67.9,62.1,61.3,35.8,29.2,14.0,13.5,7.2$; 
IR 2980 (w), 2940 (w), 1782 (w), 1720 (s), 1613 (w), 1468 (w), 1451 (w), 1368 (m), 1253 (m), 1218 (m), 1137 (m), 1071 (m), 1014 (m), 974 (m), 914 (m), 872 (m), 718 (s), 673 (m), $652(\mathrm{~m})$

HRMS (ESI) calcd for $\mathrm{C}_{26} \mathrm{H}_{28} \mathrm{NO}_{7}{ }^{+}[\mathrm{M}+\mathrm{H}]^{+} 466.1860$; found 466.1856.

HPLC analysis: Chiracel IA: 85:15 (hexane: $i$-PrOH), flow $1.0 \mathrm{~mL} / \mathrm{min}_{1}=7.9 \mathrm{~min},[\alpha]_{\mathrm{D}}^{25}-7$ (er: $\left.90: 10, c 0.4, \mathrm{CHCl}_{3}\right), \mathrm{t}_{2}=10.9$ min.

\section{Diethyl 5-(1,3-dioxoisoindolin-2-yl)-3',4,4',5-tetrahydro-2'H,3H-spiro[furan-2,1'- naphthalene]-3,3-dicarboxylate (3ah)}

Flash chromatography afforded the title compound (90 mg, $0.19 \mathrm{mmol}, 94 \%$ yield) as a colorless solid, as a single diastereoisomer (d.r. > 20:1). The assignment of the 2,5-relative configuration was made on the basis of the similarity in ${ }^{1} \mathrm{H}$ NMR spectra between $3 \mathbf{a h}$ and epi-3aa. The 2,5-cis compounds derived from aromatic ketones have the CHNPhth signal between $\delta=6.10-6.33 \mathrm{ppm}$, while epi-3aa and 3ah have this signal at $\delta=6.72$ and $6.65 \mathrm{ppm}$ respectively.

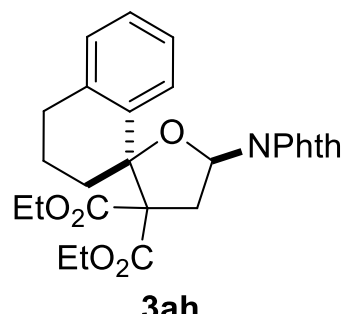

3ah
Rf 0.59 (n-hex/EtOAc 6/4);

Mp $172-174{ }^{\circ} \mathrm{C}$;

${ }^{1} \mathbf{H}$ NMR $\left(400 \mathrm{MHz}, \mathrm{CDCl}_{3}\right) \delta 8.01(\mathrm{dd}, 1 \mathrm{H}, J=7.6,1.2 \mathrm{~Hz}, \mathrm{Ar}), 7.90$ (dd, $2 \mathrm{H}, J=5.5,3.1 \mathrm{~Hz}$, Phth), 7.75 (dd, $2 \mathrm{H}, J=5.5,3.1 \mathrm{~Hz}$, Phth), $7.27(\mathrm{td}, 1 \mathrm{H}, J=7.6,1.2 \mathrm{~Hz}, \mathrm{Ar}), 7.15(\mathrm{td}, 1 \mathrm{H}, J=7.6,1.2 \mathrm{~Hz}, \mathrm{Ar})$,

7.04 (dd, $1 \mathrm{H}, J=7.6,1.2 \mathrm{~Hz}, \mathrm{Ar}), 6.65$ (dd, $1 \mathrm{H}, J=11.0,4.6 \mathrm{~Hz}, C H \mathrm{NPhth}), 4.42$ (dd, $1 \mathrm{H}$, $\left.J=13.2,11.0 \mathrm{~Hz}, \mathrm{CH}_{2} \mathrm{CHNPhth}\right), 4.38-4.22\left(\mathrm{~m}, 2 \mathrm{H}, \mathrm{OCH}_{2} \mathrm{CH}_{3}\right), 3.81$ (dq, $1 \mathrm{H}, J=10.7,7.0$ $\mathrm{Hz}, \mathrm{OCH}_{2} \mathrm{CH}_{3}$ ), $3.47\left(\mathrm{dq}, 1 \mathrm{H}, J=10.7,7.0 \mathrm{~Hz}, \mathrm{OCH}_{2} \mathrm{CH}_{3}\right), 2.86-2.69$ (m, $2 \mathrm{H}, \mathrm{CH}_{2} \mathrm{Ar}$ ), 2.50 (dd, $1 \mathrm{H}, J=13.2,4.6 \mathrm{~Hz}, \mathrm{CH}_{2} \mathrm{CHNPhth}$ ), 2.46-2.37 (m, $1 \mathrm{H}, \mathrm{CH}_{2} \mathrm{CH}_{2} \mathrm{Ar}$ ), 2.32-2.21 (m, $1 \mathrm{H}$, $\mathrm{CH}_{2} \mathrm{CH}_{2} \mathrm{Ar}$ ), 2.08-1.95 (m, $\left.1 \mathrm{H}, \mathrm{CH}_{2} \mathrm{CH}_{2} \mathrm{CH}_{2} \mathrm{Ar}\right), 1.87-1.74$ (m, $1 \mathrm{H}, \mathrm{CH}_{2} \mathrm{CH}_{2} \mathrm{CH}_{2} \mathrm{Ar}$ ), 1.36 (t, $\left.3 \mathrm{H}, J=7.0 \mathrm{~Hz}, \mathrm{OCH}_{2} \mathrm{CH}_{3}\right), 0.87\left(\mathrm{t}, 3 \mathrm{H}, \mathrm{J}=7.0 \mathrm{~Hz}, \mathrm{OCH}_{2} \mathrm{CH}_{3}\right)$;

${ }^{13}$ C NMR (101 MHz, $\left.\mathrm{CDCl}_{3}\right) \delta 170.6,168.7,167.8,139.4,138.0,134.4,131.8,128.4,127.9$, $127.5,126.2,123.6,85.4,79.9,69.3,62.2,61.3,36.0,35.2,30.0,19.8,14.0,13.3$;

IR 2982 (w), 2939 (w), 2938 (w), 1781 (w), 1720 (s), 1468 (w), 1452 (w), 1367 (m), 1305 (m), 1258 (m), 1207 (w), 1195 (w), 1140 (m), 1112 (m), 1092 (m), 1061 (m), 1050 (m), 1014 (m), 1006 (m), $976(\mathrm{w}), 914(\mathrm{~m}), 874(\mathrm{~m}), 764(\mathrm{~m}), 718(\mathrm{~s}), 653(\mathrm{~m})$;

HRMS (ESI) calcd for $\mathrm{C}_{27} \mathrm{H}_{27} \mathrm{NNaO}_{7}^{+}[\mathrm{M}+\mathrm{Na}]^{+}$500.1680; found 500.1672.

HPLC analysis: Chiracel IA: 85:15 (hexane: $i$-PrOH), flow $1.0 \mathrm{~mL} / \mathrm{min} . \mathrm{t}_{1}=11.3 \mathrm{~min},[\alpha]_{\mathrm{D}}^{25}$ 115 (er: 98:2, $\left.c 0.3, \mathrm{CHCl}_{3}\right), \mathrm{t}_{2}=15.4$ min. 


\section{Diethyl 5-(1,3-dioxoisoindolin-2-yl)-2,2-dimethyldihydrofuran-3,3(2H)-dicarboxylate}

(3ai)

Flash chromatography afforded the title compound (74 mg, $0.19 \mathrm{mmol}, 94 \%$ yield) as a colorless solid.

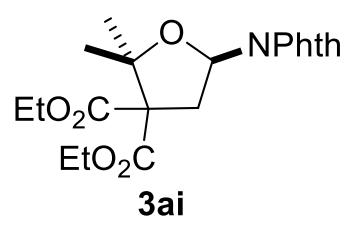

$\mathbf{R}_{\mathbf{f}} 0.54$ (n-hex/EtOAc 6/4);

Mp $126-127^{\circ} \mathrm{C}$;

${ }^{1} \mathbf{H}$ NMR $\left(400 \mathrm{MHz}, \mathrm{CDCl}_{3}\right) \delta 7.86(\mathrm{dd}, 2 \mathrm{H}, J=5.5,3.1 \mathrm{~Hz}, \mathrm{Phth})$, $7.74(\mathrm{dd}, 2 \mathrm{H}, J=5.5,3.1 \mathrm{~Hz}$, Phth), $6.37(\mathrm{dd}, 1 \mathrm{H}, J=9.3,6.7 \mathrm{~Hz}$, CHNPhth), $4.28\left(\mathrm{q}, 4 \mathrm{H}, J=7.0 \mathrm{~Hz}, \mathrm{OCH}_{2} \mathrm{CH}_{3}\right), 3.92(\mathrm{dd}, 1 \mathrm{H}, J=13.6,9.3 \mathrm{~Hz}$, $\mathrm{CH}_{2} \mathrm{CHNPhth}$ ), 2.56 (dd, $1 \mathrm{H}, \mathrm{J}=13.6,6.7 \mathrm{~Hz}, \mathrm{CH}_{2} \mathrm{CHNPhth}$ ), 1.60 (s, $3 \mathrm{H}, \mathrm{CH}_{3}$ ), 1.60 (s, 3 $\left.\mathrm{H}, \mathrm{CH}_{3}\right), 1.33\left(\mathrm{t}, 3 \mathrm{H}, J=7.0 \mathrm{~Hz}, \mathrm{OCH}_{2} \mathrm{CH}_{3}\right), 1.32$ (t, $\left.3 \mathrm{H}, J=7.0 \mathrm{~Hz}, \mathrm{OCH}_{2} \mathrm{CH}_{3}\right)$;

${ }^{13} \mathrm{C}$ NMR $\left(101 \mathrm{MHz}, \mathrm{CDCl}_{3}\right) \delta 166.6,165.1,164.7,132.6,130.2,122.3,84.7,79.6,67.9$, $63.3,63.0,35.9,30.0,28.4,17.6,17.5$;

IR 2983 (w), 2941 (w), 1779 (w), 1717 (s), 1468 (w), 1366 (m), 1330 (m), 1266 (m), 1206 (m), 1158 (w), 1126 (m), 1086 (m), 1017 (m), 995 (m), 959 (w), 912 (w), 876 (m), $832(\mathrm{w})$, $795(\mathrm{w}), 720(\mathrm{~s}), 653(\mathrm{~m})$;

HRMS (ESI) calcd for $\mathrm{C}_{20} \mathrm{H}_{23} \mathrm{NNaO}_{7}^{+}[\mathrm{M}+\mathrm{Na}]^{+}$412.1367; found 412.1362.

HPLC analysis: Chiracel IA: 95:5 (hexane: $i$-PrOH), flow $1.0 \mathrm{~mL} / \mathrm{min} . \mathrm{t}_{1}=13.8 \mathrm{~min},[\alpha]_{\mathrm{D}}^{25}$ $+12\left(\mathrm{er}: 97.5: 2.5, c 0.3, \mathrm{CHCl}_{3}\right), \mathrm{t}_{2}=14.7 \mathrm{~min}$

\section{Diethyl 2-(1,3-dioxoisoindolin-2-yl)-1-oxaspiro[4.5]decane-4,4-dicarboxylate (3aj)}

Flash chromatography afforded the title compound (86 $\mathrm{mg}, 0.20 \mathrm{mmol}, 99 \%$ yield) as a colorless solid.

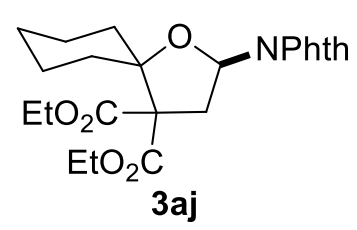

Rf 0.66 ( $n$-hex/EtOAc 6/4);

Mp $97-98{ }^{\circ} \mathrm{C}$;

${ }^{1}$ H NMR (400 MHz, $\left.\mathrm{CDCl}_{3}\right) \delta 7.89$ (dd, $2 \mathrm{H}, J=5.5,3.1 \mathrm{~Hz}$, Phth), $7.76(\mathrm{dd}, 2 \mathrm{H}, J=5.5,3.1 \mathrm{~Hz}$, Phth), 6.39 (dd, $1 \mathrm{H}, J=9.4,6.6 \mathrm{~Hz}$, CHNPhth), 4.34-4.20 (m, $4 \mathrm{H}, \mathrm{OCH}_{2} \mathrm{CH}_{3}$ ), 3.83 (dd, $1 \mathrm{H}, J=13.5,9.4 \mathrm{~Hz}, \mathrm{CH}_{2} \mathrm{CHNPhth}$ ), 2.52 (dd, $1 \mathrm{H}, J=13.5,6.6 \mathrm{~Hz}, \mathrm{CH}_{2} \mathrm{CHNPhth}$ ), 2.48-2.41 (m, $1 \mathrm{H}$, cyclohexyl), 1.81-1.69 (m, $2 \mathrm{H}$, cyclohexyl), 1.66-1.44 (m, $6 \mathrm{H}$, cyclohexyl), 1.34 (t, $\left.6 \mathrm{H}, \mathrm{J}=7.1 \mathrm{~Hz}, \mathrm{OCH}_{2} \mathrm{CH}_{3}\right), 1.24-$ 1.09 (m, $1 \mathrm{H}$, cyclohexyl);

${ }^{13}$ C NMR $\left(101 \mathrm{MHz}, \mathrm{CDCl}_{3}\right) \delta 169.6,168.3,167.9,134.2,131.9,123.5,85.8,78.9,67.2$, $61.8,61.4,33.3,33.0,32.8,25.3,22.8,21.7,14.1,14.0$; 
IR 2982 (w), 2937 (w), 2863 (w), 1779 (w), 1720 (s), 1468 (w), 1453 (w), 1367 (m), 1331 (w), 1302 (m), 1284 (m), 1265 (m), 1219 (w), 1207 (w), 1139 (m), 1118 (m), 1101 (m), 1073 (m), 1053 (w), $1018(\mathrm{~m}), 989(\mathrm{w}), 874(\mathrm{w}), 796(\mathrm{w}), 730(\mathrm{~m}), 656(\mathrm{w}), 656(\mathrm{w})$;

HRMS (ESI) calcd for $\mathrm{C}_{23} \mathrm{H}_{28} \mathrm{NO}_{7}^{+}[\mathrm{M}+\mathrm{H}]^{+} 430.1860$; found 430.1859.

HPLC analysis: Chiracel IA: 85:15 (hexane: $i$-PrOH), flow $1.0 \mathrm{~mL} / \mathrm{min} . \mathrm{t}_{1}=8.3 \mathrm{~min},[\alpha]_{\mathrm{D}}^{25}-$ 22 (er: 98:2, $c$ 0.2, $\left.\mathrm{CHCl}_{3}\right), \mathrm{t}_{2}=9.4 \mathrm{~min}$.

\section{Dimethyl 2-(1,3-dioxoisoindolin-2-yl)-1-oxaspiro[4.5]decane-4,4-dicarboxylate (3bj)}

Flash chromatography afforded the title compound (80 mg, $0.20 \mathrm{mmol}, 99 \%$ yield) as a colorless solid.

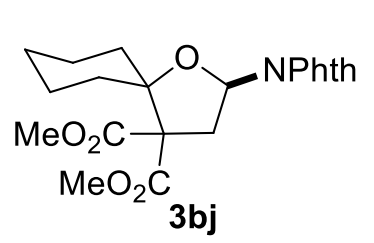

$\mathbf{R}_{\mathbf{f}} 0.57$ (n-hex/EtOAc 6/4);

Мp 163-165 ${ }^{\circ} \mathrm{C}$;

${ }^{1}$ H NMR (400 MHz, $\left.\mathrm{CDCl}_{3}\right) \delta 7.89(\mathrm{dd}, 2 \mathrm{H}, J=5.4,3.0 \mathrm{~Hz}, \mathrm{Phth})$, $7.76(\mathrm{dd}, 2 \mathrm{H}, J=5.4,3.0 \mathrm{~Hz}$, Phth), 6.38 (dd, $1 \mathrm{H}, J=9.3,6.7 \mathrm{~Hz}$, CHNPhth), 3.96 (dd, $1 \mathrm{H}, J=13.6,9.3 \mathrm{~Hz}, \mathrm{CH}_{2} \mathrm{CHNPhth}$ ), 3.83 (s, $6 \mathrm{H}, \mathrm{OCH}_{3}$ ), 2.55 (dd, 1 $\left.\mathrm{H}, J=13.6,6.7 \mathrm{~Hz}, \mathrm{CH}_{2} \mathrm{CHNPhth}\right), 2.50-2.37$ (m, $1 \mathrm{H}$, cyclohexyl), 1.82-1.65 (m, $2 \mathrm{H}$, cyclohexyl), 1.64-1.40 (m, $6 \mathrm{H}$, cyclohexyl), 1.30-1.07 (m, $1 \mathrm{H}$, cyclohexyl);

${ }^{13} \mathrm{C}$ NMR $\left(101 \mathrm{MHz}, \mathrm{CDCl}_{3}\right) \delta 170.1,168.7,167.9,134.4,131.8,123.6,86.0,78.9,67.3$, 52.8, 52.6, 33.1, 33.1, 32.7, 25.2, 22.8, 21.7;

IR 2951 (w), 2936 (w), 2860 (w), 1776 (w), 1735 (s), 1717 (s), 1613 (w), 1455 (w), 1369 (m), 1355 (m), 1288 (m), 1267 (m), 1214 (m), 1138 (m), 1118 (m), 1090 (m), 1072 (m), 1053 (m), $993(\mathrm{~m}), 946(\mathrm{w}), 912(\mathrm{~s}), 874(\mathrm{w}), 729(\mathrm{~s}), 651(\mathrm{~m})$;

HRMS (ESI) calcd for $\mathrm{C}_{21} \mathrm{H}_{24} \mathrm{NO}_{7}{ }^{+}[\mathrm{M}+\mathrm{H}]^{+} 402.1547$; found 402.1563 .

\section{Dimethyl 5-(1,3-dioxoisoindolin-2-yl)-2-ethyl-2-methyldihydrofuran-3,3(2H)- dicarboxylate (3bk)}

Flash chromatography afforded the title compound (67 $\mathrm{mg}, 0.18 \mathrm{mmol}, 89 \%$ yield) as a colorless solid, as an inseparable mixture of diastereoisomers; d.r. = 10:1 determined by

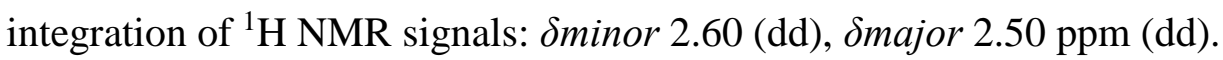

Recrystallization from $i \mathrm{PrOH}$ gave increased d.r. in favour of the cis isomer (16:1).

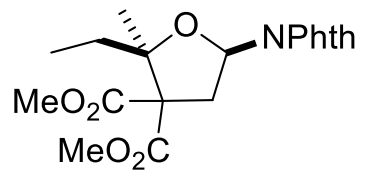

3bk

$\mathbf{R}_{\mathbf{f}} 0.50$ ( $n$-hex/EtOAc 6/4);

Mp $135-136^{\circ} \mathrm{C}$;

${ }^{1} \mathbf{H}$ NMR (cis isomer, $\left.400 \mathrm{MHz}, \mathrm{CDCl}_{3}\right) \delta 7.89(\mathrm{dd}, 2 \mathrm{H}, J=5.5,3.1$

Hz, Phth), 7.76 (dd, 2 H, $J=5.5,3.1 \mathrm{~Hz}$, Phth), 6.40 (dd, $1 \mathrm{H}, J=9.4$, 
6.7 Hz, CHNPhth), 3.96 (dd, $1 \mathrm{H}, J=13.7,9.4 \mathrm{~Hz}, \mathrm{CH}_{2} \mathrm{CHNPhth}$ ), 3.84 (s, $3 \mathrm{H}, \mathrm{OCH}_{3}$ ), 3.82 (s, $3 \mathrm{H}, \mathrm{OCH}_{3}$ ), 2.52 (dd, $1 \mathrm{H}, J=13.7,6.7 \mathrm{~Hz}, \mathrm{CH}_{2} \mathrm{CHNPhth}$ ), 2.23-2.09 (m, $1 \mathrm{H}, \mathrm{CH}_{2} \mathrm{CH}_{3}$ ), 1.73-1.59 (m, $\left.1 \mathrm{H}, \mathrm{CH}_{2} \mathrm{CH}_{3}\right), 1.39$ (s, $\left.3 \mathrm{H}, \mathrm{CH}_{3}\right), 0.87$ (t, $3 \mathrm{H}, \mathrm{CH}_{2} \mathrm{CH}_{3}$ );

${ }^{13} \mathrm{C}$ NMR (cis isomer, $101 \mathrm{MHz}, \mathrm{CDCl}_{3}$ ) $\delta$ 170.4, 168.7, 167.9, 134.4, 131.7, 123.6, 86.5, 79.2, 67.8, 52.9, 52.6, 32.9, 30.0, 20.7, 7.7;

IR 2985 (w), 2954 (w), 1782 (w), 1716 (s), 1467 (w), 1456 (w), 1435 (w), 1366 (m), 1358 (m), 1310 (m), 1267 (m), 1219 (m), 1205 (m), 1122 (m), 1087 (m), 1036 (m), 1017 (m), 990 (m), $972(\mathrm{~m}), 914(\mathrm{~m}), 887(\mathrm{~m}), 779(\mathrm{w}), 722$ (s), $651(\mathrm{~m})$;

HRMS (ESI) calcd for $\mathrm{C}_{19} \mathrm{H}_{22} \mathrm{NO}_{7}{ }^{+}[\mathrm{M}+\mathrm{H}]^{+} 376.1391$; found 376.1395 .

\section{Dimethyl 2-cyclopropyl-5-(1,3-dioxoisoindolin-2-yl)-2-methyldihydrofuran-3,3(2H)- dicarboxylate (3bl)}

Flash chromatography afforded the title compound (74 mg, $0.19 \mathrm{mmol}, 96 \%$ yield) as a colorless solid, as as a single diastereoisomer (d.r. > 20:1).

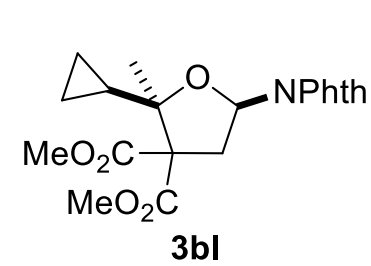

9.9, 6.0 Hz, CHNPhth), 4.12 (dd, $1 \mathrm{H}, J=13.5,9.9 \mathrm{~Hz}, \mathrm{CH}_{2} \mathrm{CHNPhth}$ ), 3.75 (s, $3 \mathrm{H}, \mathrm{OCH}_{3}$ ), 3.74 (s, $3 \mathrm{H}, \mathrm{OCH}_{3}$ ), 2.39 (dd, $\left.1 \mathrm{H}, J=13.5,6.0 \mathrm{~Hz}, \mathrm{CH}_{2} \mathrm{CHNPhth}\right), 1.64-1.55$ (m, $1 \mathrm{H}$, cyclopropyl), 1.18 (s, $\left.3 \mathrm{H}, \mathrm{CH}_{3}\right), 0.64-0.57$ (m, $1 \mathrm{H}$, cyclopropyl), 0.43-0.24 (m, $3 \mathrm{H}$, cyclopropyl);

${ }^{13}$ C NMR (101 MHz, THF-d8) $\delta$ 170.8, 168.7, 168.0, 134.9, 132.8, 123.7, 85.9, 79.7, 68.0, 52.5, 52.0, 34.3, 19.6, 19.1, 3.8, 1.5;

IR 3011 (w), 2954 (w), 1781 (w), 1717 (s), 1436 (w), 1395 (w), 1369 (m), 1330 (m), 1270 (m), 1219 (m), 1205 (m), 1151 (w), 1118 (m), 1081 (m), 1050 (m), 1025 (w), 1013 (w), 993 (m), $974(\mathrm{w}), 923(\mathrm{w}), 887(\mathrm{~m})$;

HRMS (ESI) calcd for $\mathrm{C}_{20} \mathrm{H}_{22} \mathrm{NO}_{7}^{+}[\mathrm{M}+\mathrm{H}]^{+} 388.1391$; found 388.1394.

\section{Diethyl 2-(1,3-dioxoisoindolin-2-yl)-6-isopropyl-9-methyl-1-oxaspiro[4.5]decane-4,4- dicarboxylate (3am)}

Flash chromatography afforded the title compound (85 $\mathrm{mg}, 0.175 \mathrm{mmol}, 88 \%$ yield) as a colorless solid, as a single diastereoisomer (d.r. > 20:1).

[6] The compound proved to be sensitive to traces of acid present in $\mathrm{CDCl}_{3}$. 


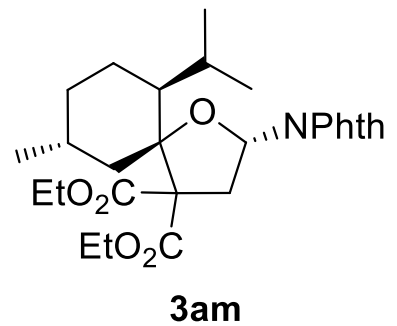

$[\alpha]_{\mathrm{D}}^{25}-23\left(\right.$ c 0.4, $\left.\mathrm{CHCl}_{3}\right)$;

$\mathbf{R}_{\mathbf{f}} 0.75$ (n-hex/EtOAc 6/4);

Mp $136-138{ }^{\circ} \mathrm{C}$;

${ }^{1} \mathbf{H}$ NMR $\left(400 \mathrm{MHz}, \mathrm{CDCl}_{3}\right) \delta 7.89(\mathrm{dd}, 2 \mathrm{H}, J=5.5,3.1 \mathrm{~Hz}, \mathrm{Phth})$, 7.76 (dd, $2 \mathrm{H}, J=5.5,3.1 \mathrm{~Hz}$, Phth), 6.19 (dd, $1 \mathrm{H}, J=11.0,4.0 \mathrm{~Hz}$, CHNPhth), 4.32-4.19 (m, $4 \mathrm{H}, \mathrm{OCH}_{2} \mathrm{CH}_{3}$ ), 3.97 (dd, $1 \mathrm{H}, J=12.7,11.0 \mathrm{~Hz}, \mathrm{CH}_{2} \mathrm{CHNPhth}$ ), 2.58 (dd, $1 \mathrm{H}, J=12.7,4.0 \mathrm{~Hz}, \mathrm{CH}_{2} \mathrm{CHNPhth}$ ), 2.03 (dd, $1 \mathrm{H}, J=12.2,4.2 \mathrm{~Hz}$, menthyl), 1.81-1.55 (m, $6 \mathrm{H}$, menthyl), 1.52-1.24 (m, $2 \mathrm{H}$, menthyl), 1.33 (m, $\left.6 \mathrm{H}, \mathrm{OCH}_{2} \mathrm{CH}_{3}\right), 1.00-0.67$ $\left(\mathrm{m}, 9 \mathrm{H}, i \mathrm{Pr}+\mathrm{CH}_{3}\right)$;

${ }^{13} \mathrm{C}$ NMR $\left(101 \mathrm{MHz}, \mathrm{CDCl}_{3}\right) \delta 170.6,168.5,168.0,134.3,131.8,123.5,89.9,78.9,66.7$, 62.1, 61.6, 46.1, 44.5, 35.1, 34.2, 29.4, 27.8, 22.8, 22.6, 22.3, 19.1, 14.0, 13.9;

IR 2951 (w), 2931 (w), 2870 (w), 1782 (w), 1722 (s), 1467 (w), 1457 (w), 1368 (m), 1328 (w), 1299 (w), 1270 (w), 1250 (m), 1231 (m), 1208 (m), 1155 (w), 1130 (m), $1106(\mathrm{~m}), 1087$ (m), $1063(\mathrm{~m}), 1030(\mathrm{w}), 1013(\mathrm{~m}), 1002(\mathrm{~m}), 985(\mathrm{w}), 943(\mathrm{w}), 912(\mathrm{w}), 873(\mathrm{w}), 849(\mathrm{w})$; HRMS (ESI) calcd for $\mathrm{C}_{27} \mathrm{H}_{36} \mathrm{NO}_{7}^{+}[\mathrm{M}+\mathrm{H}]^{+} 486.2486$; found 486.2493 .

\section{Enantiospecific reactions}

All reactions were performed on $16 \mathrm{mg}(0.05 \mathrm{mmol}, 1 \mathrm{eq})$ of enantioenriched aminocyclopropane 1a $(e e=96 \%)$ or ent-1a $(e e=96 \%)$, following the standard procedure for the tin-catalysed [3+2] annulation (S8). 


\section{HPLC traces}
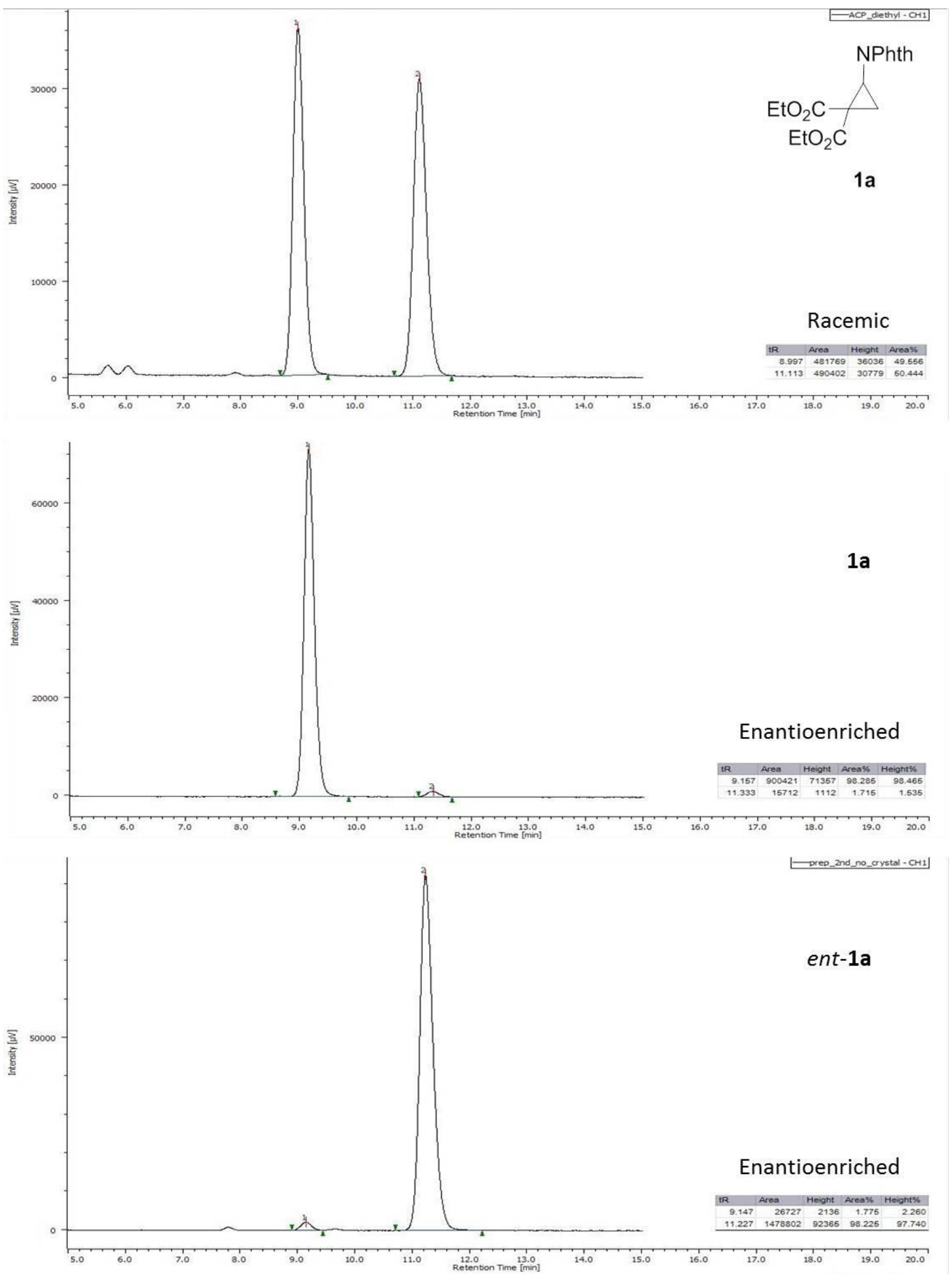


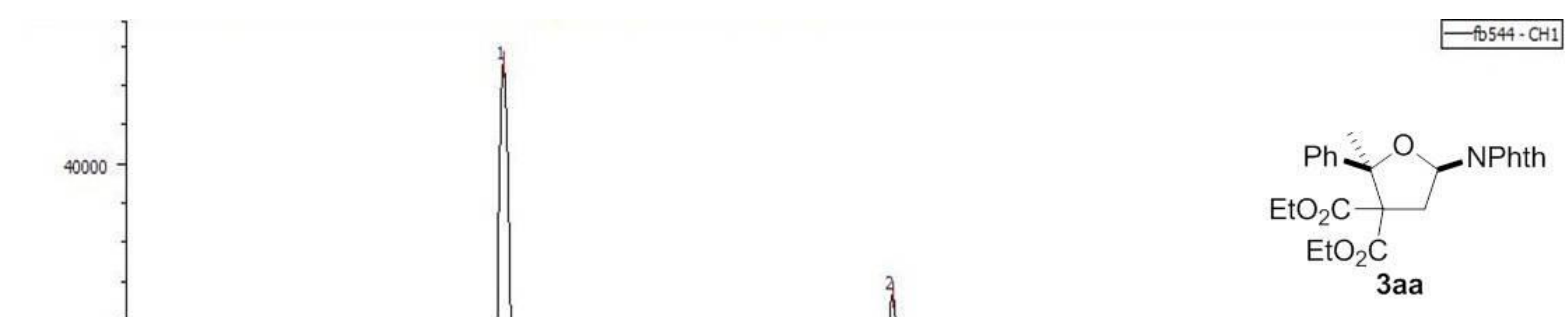

Racemic

tR Area Height Area\%

$\begin{array}{lllll}8.927 & 635343 & 45255 & 50.926\end{array}$ \begin{tabular}{l|l|l|l|}
12.993 & 612231 & 33664 & 49.074 \\
\hline
\end{tabular}
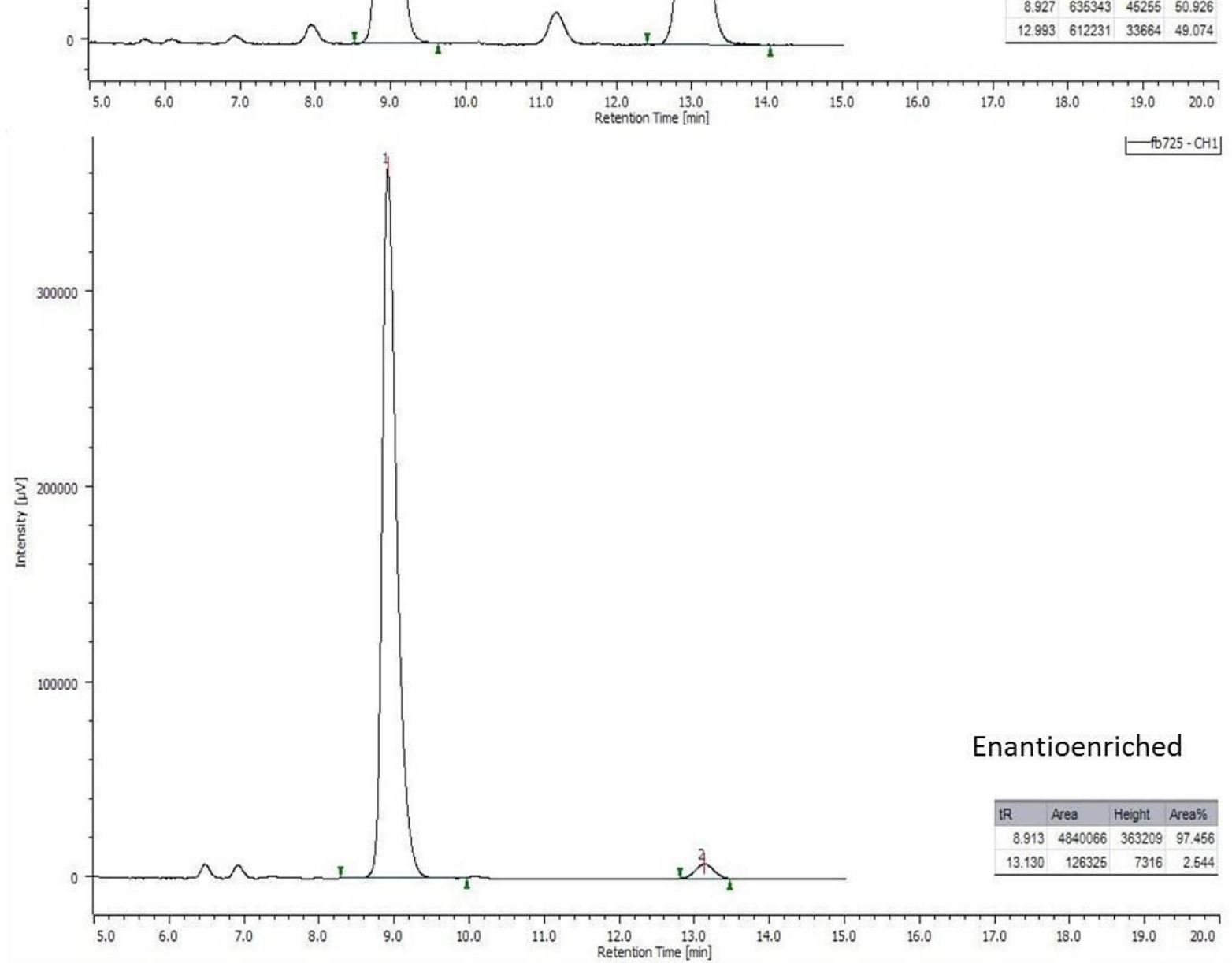

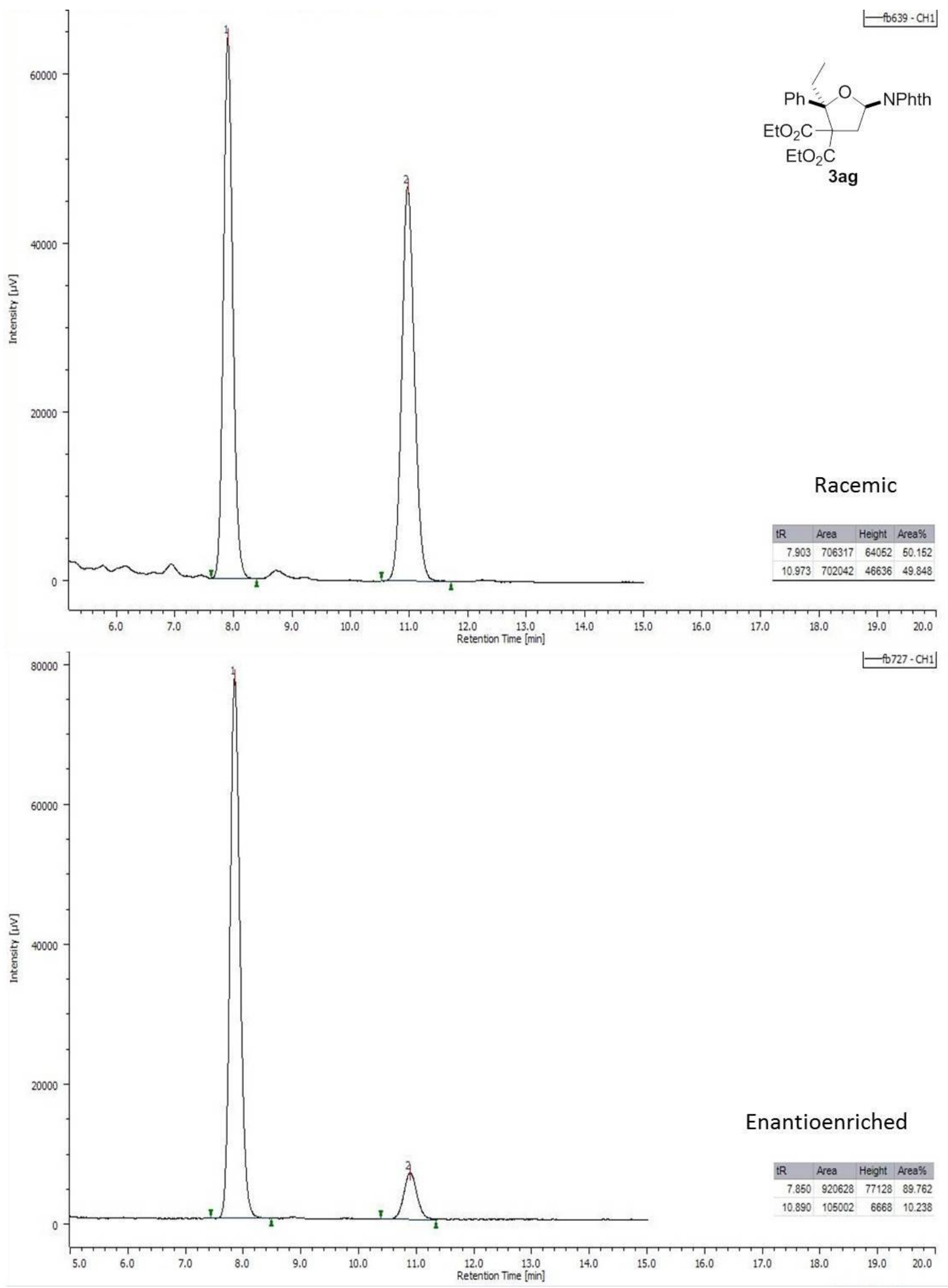

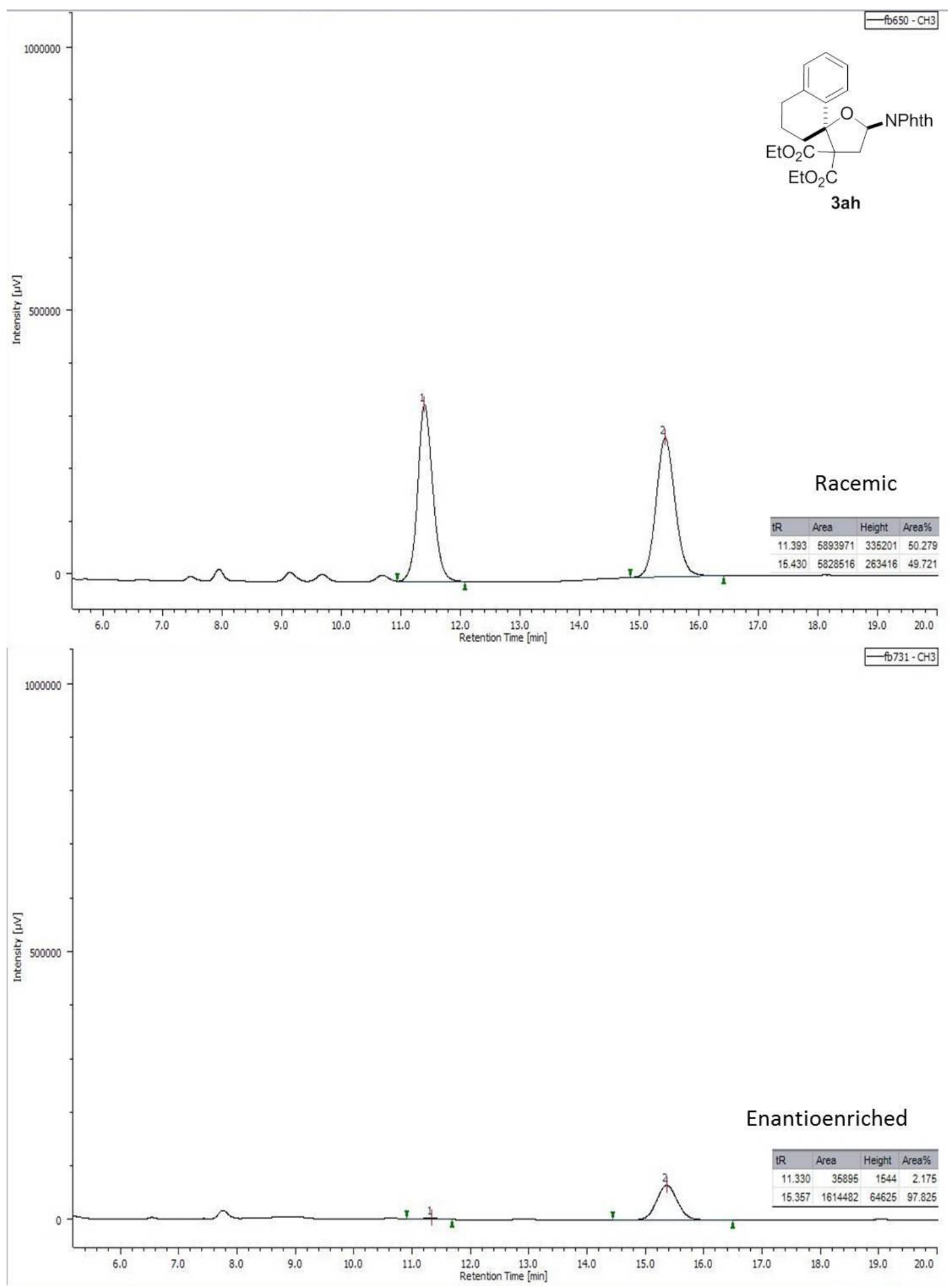


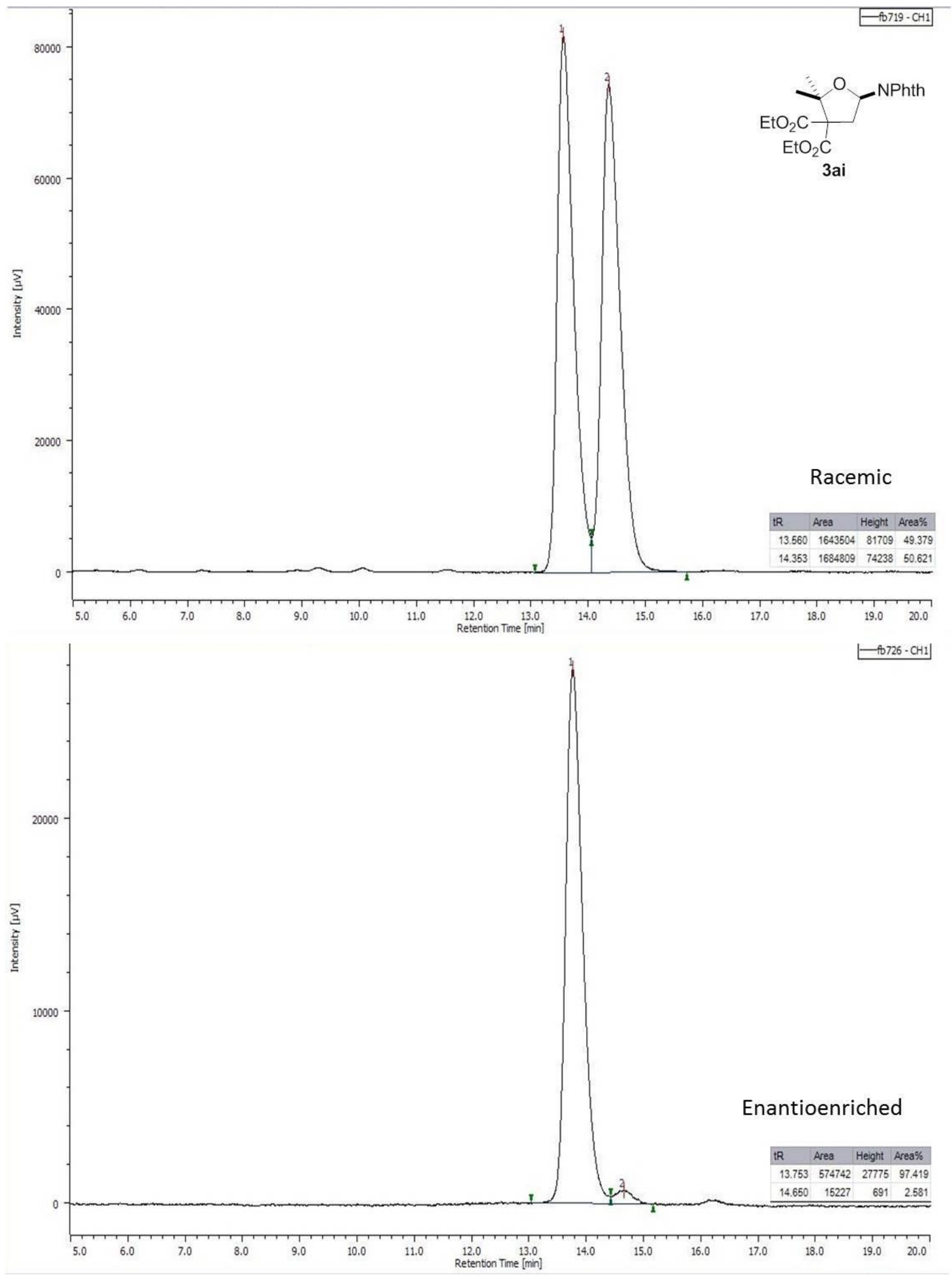



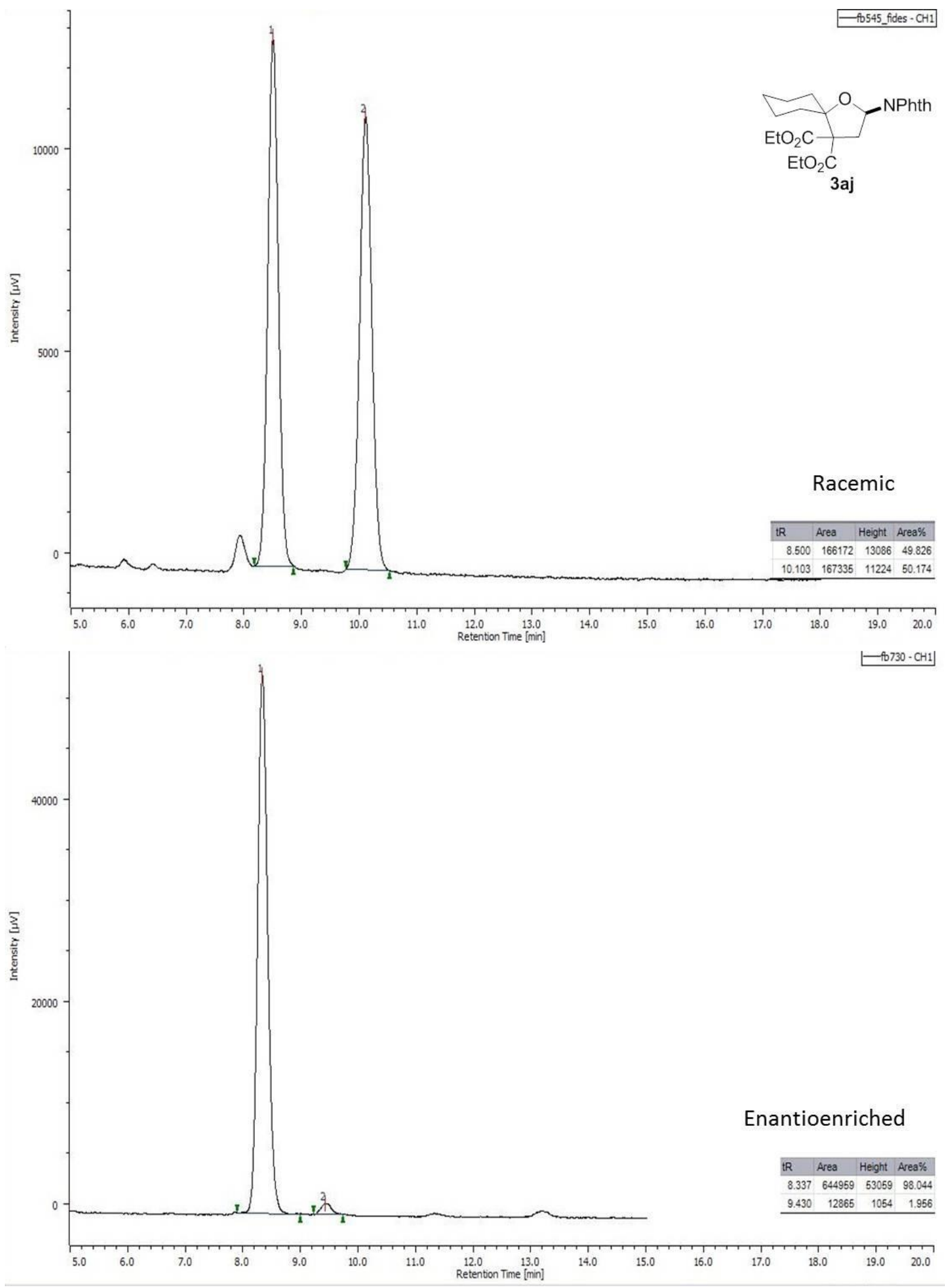


\section{Spectra}

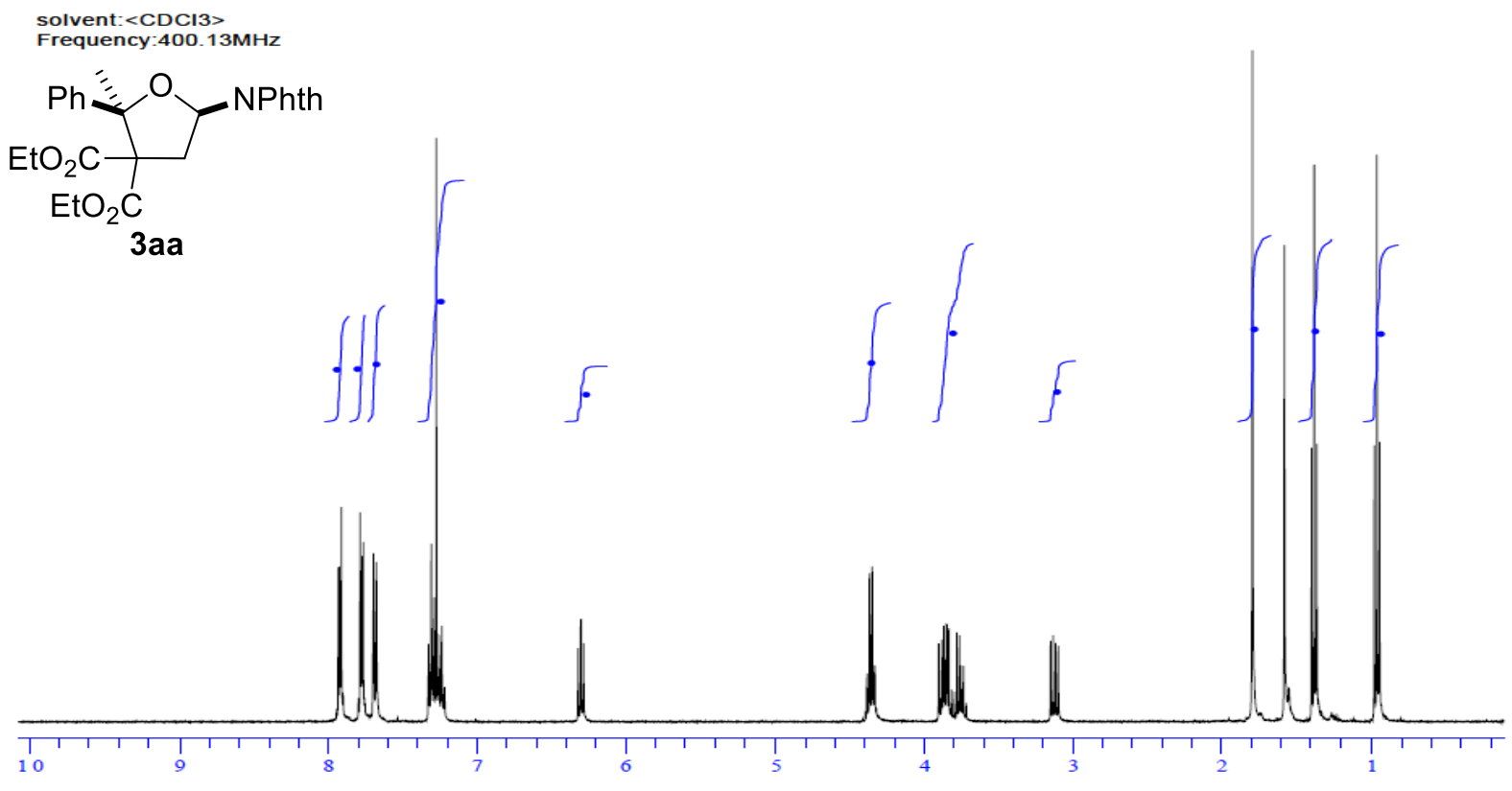

solvent:<CDCl3>

Frequency: 100.612769MHz
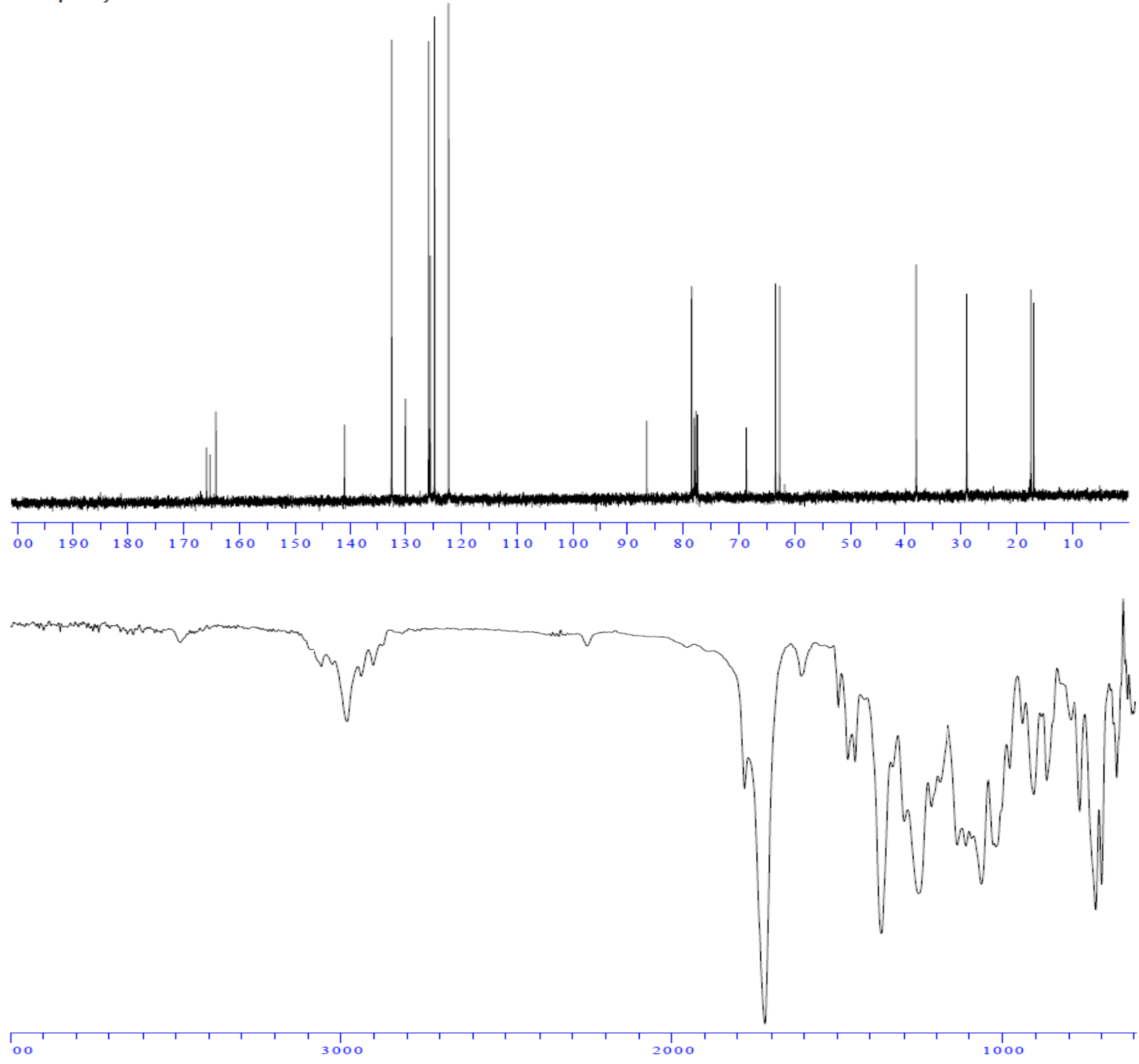
solvent:<CDCl3>

Frequency:400 $13 \mathrm{MHz}$

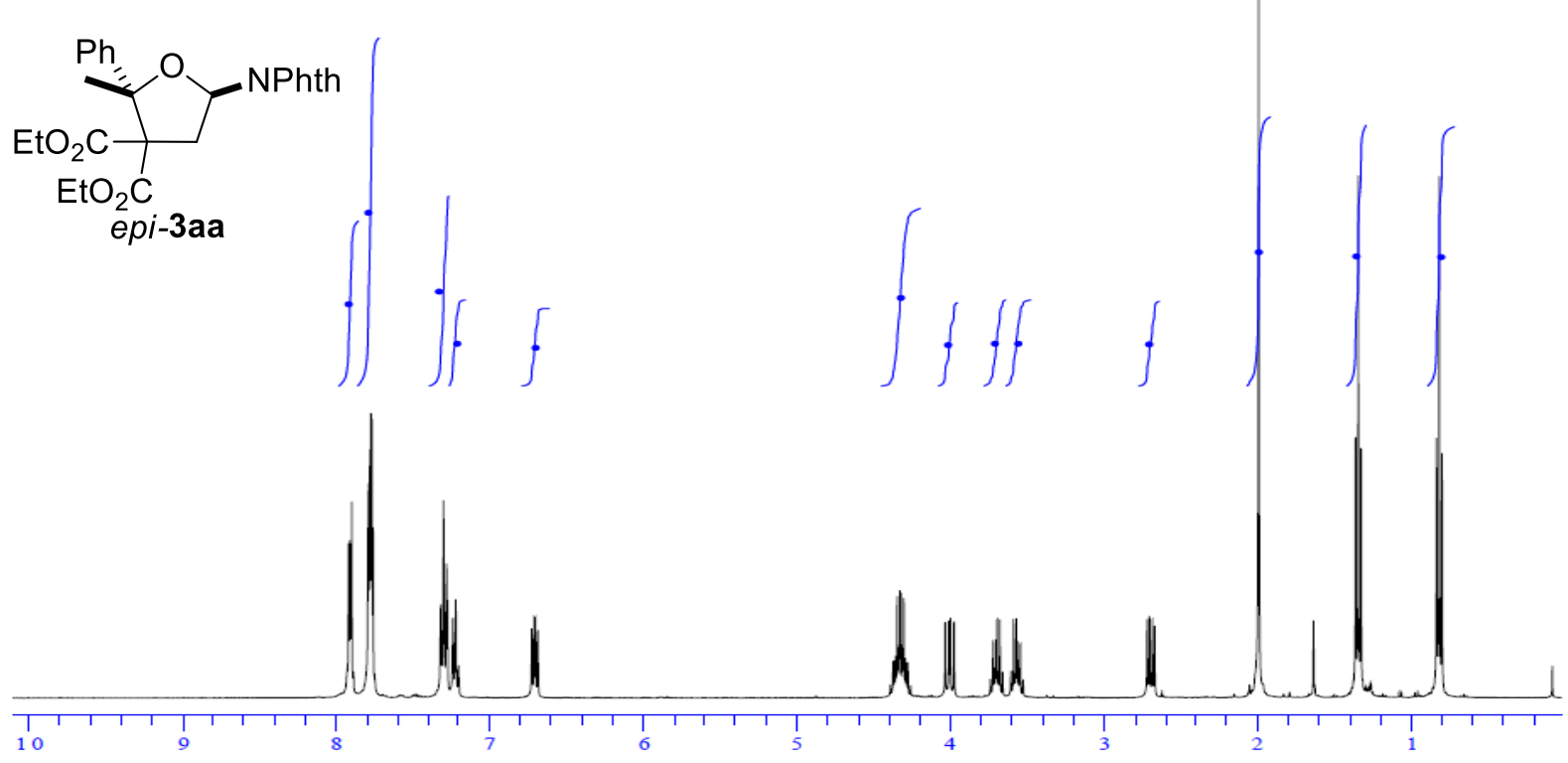

Solvent: $<\mathrm{CDCl} 3>$

Frequency: $100.612769 \mathrm{MHz}$
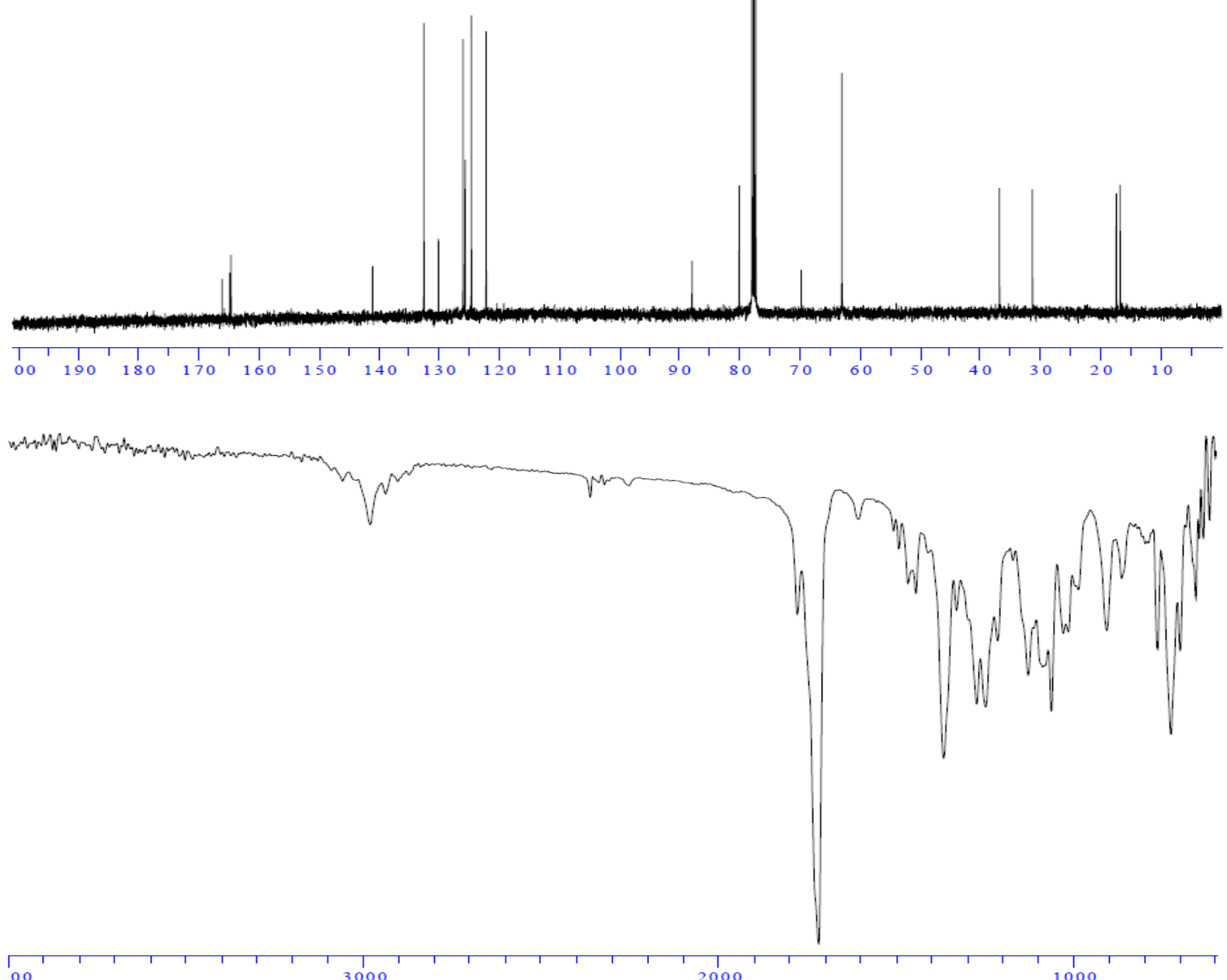
solvent:<CDCI3>

Frequency:400.13MHz
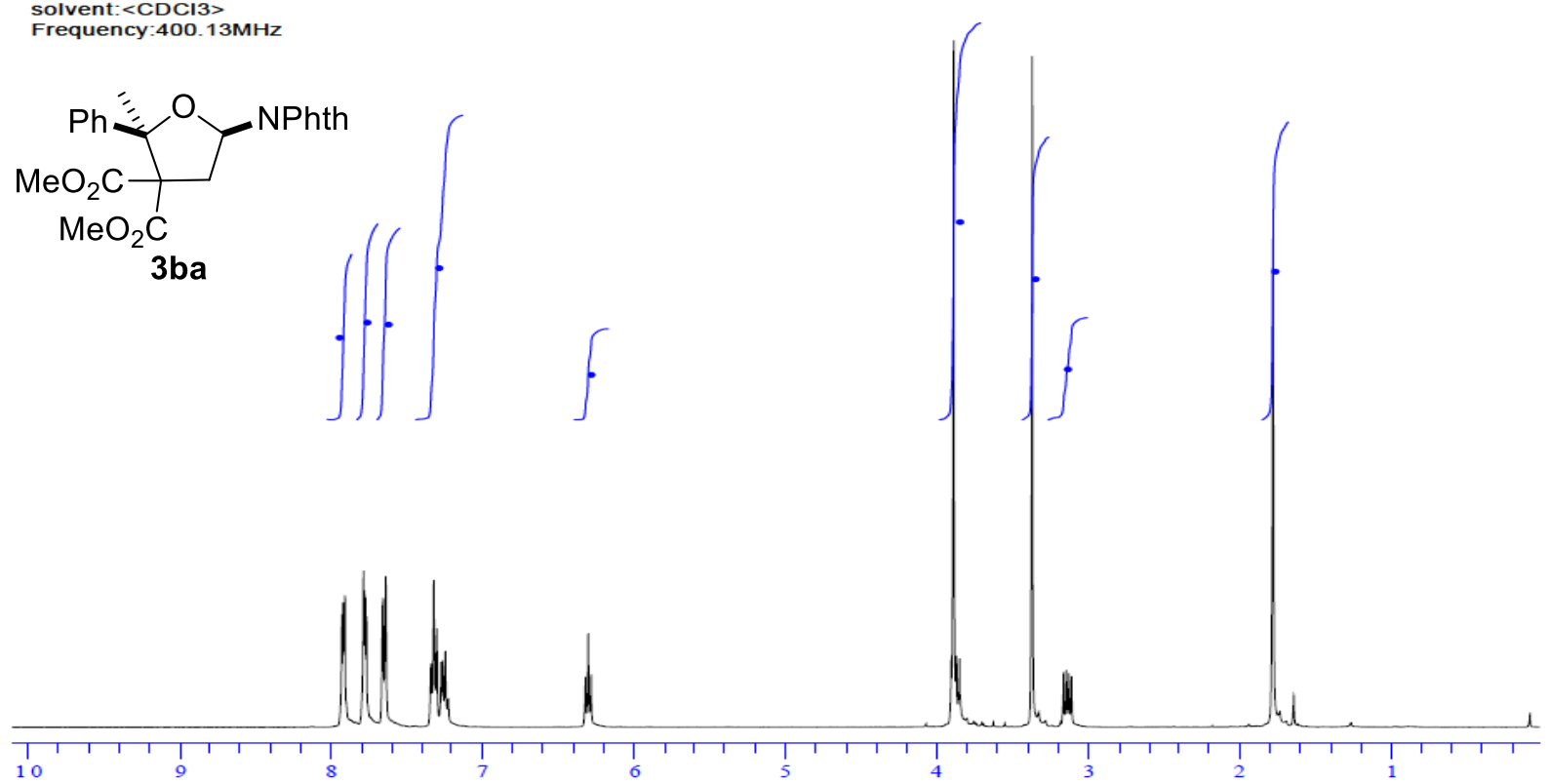

solvent:<CDCI3>

Frequency: 100.612769MHz
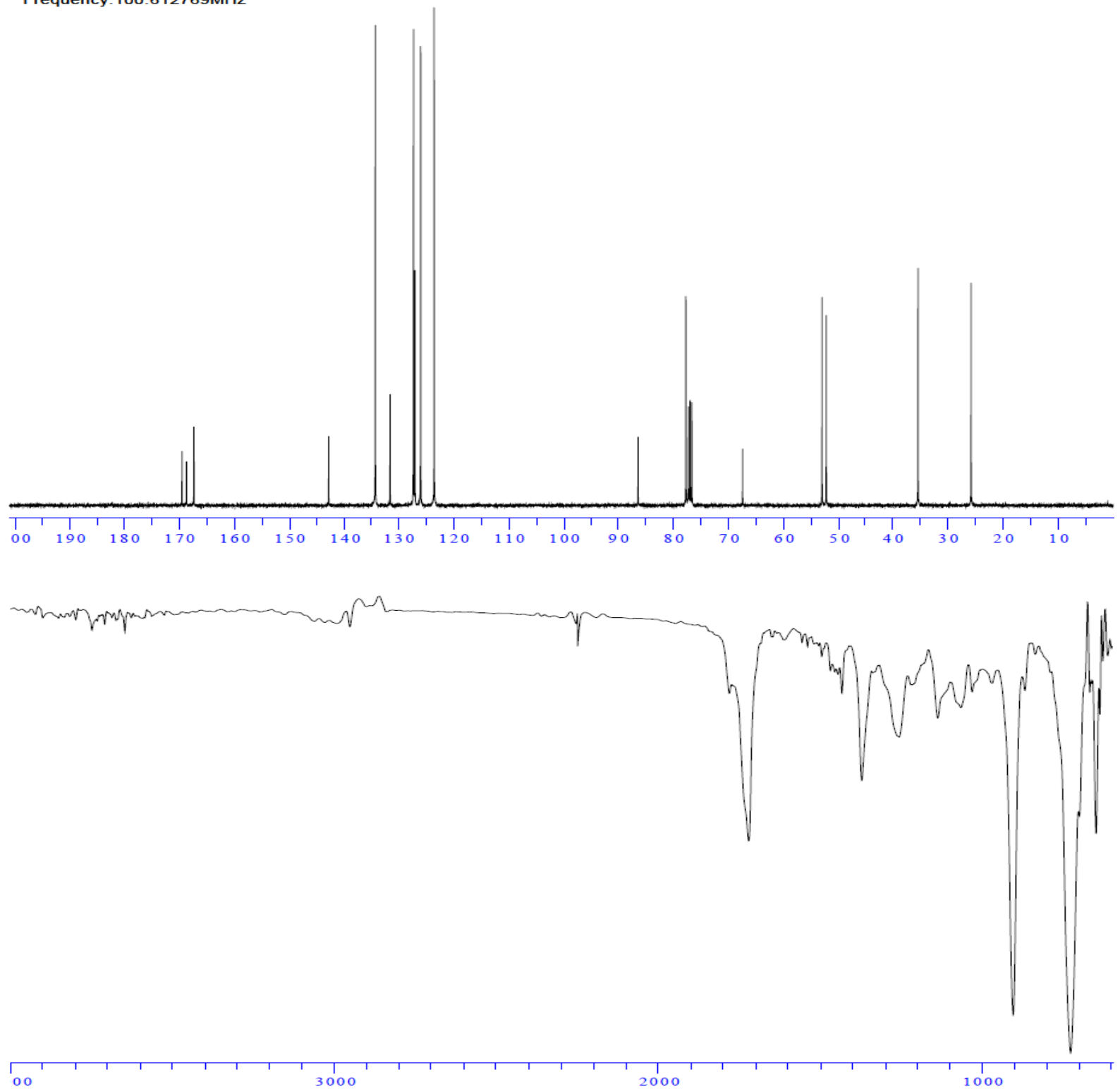
solvent: $<\mathrm{CDCl} 3>$

Frequency:400.13MHz
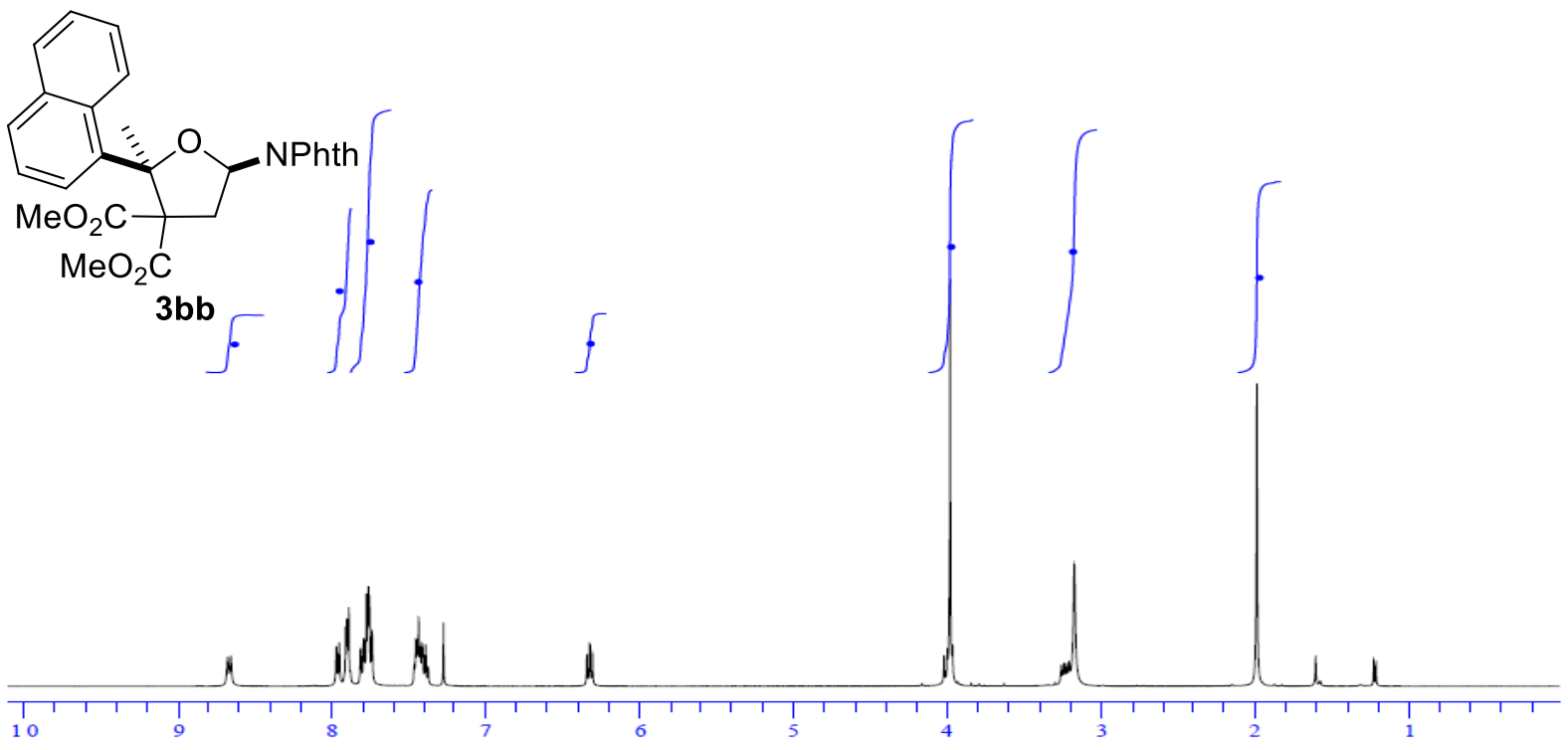

solvent: $<\mathrm{CDCl} 3>$

Frequency: $100.612769 \mathrm{MHz}$
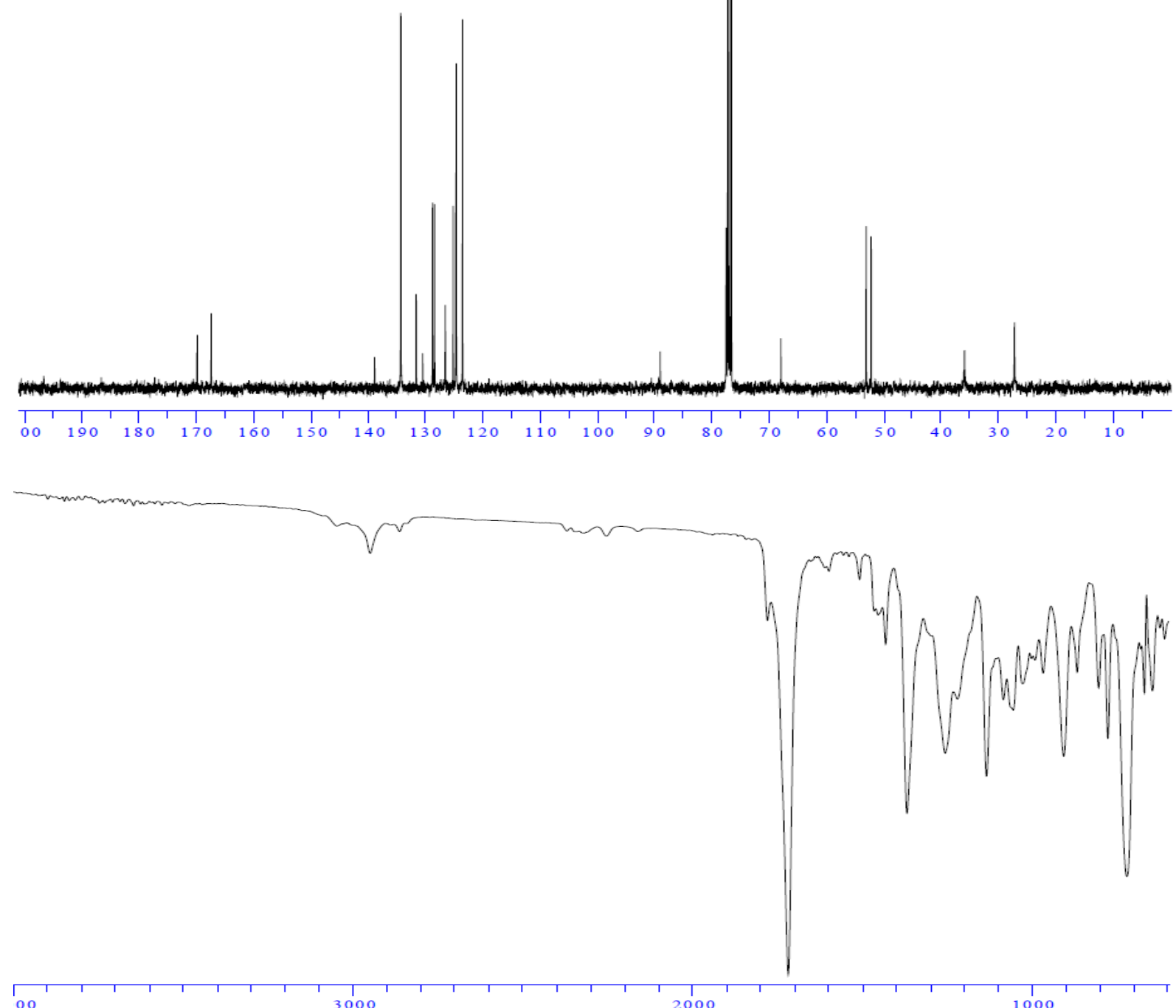
solvent:<CDCI3>

Frequency-400.13MHz

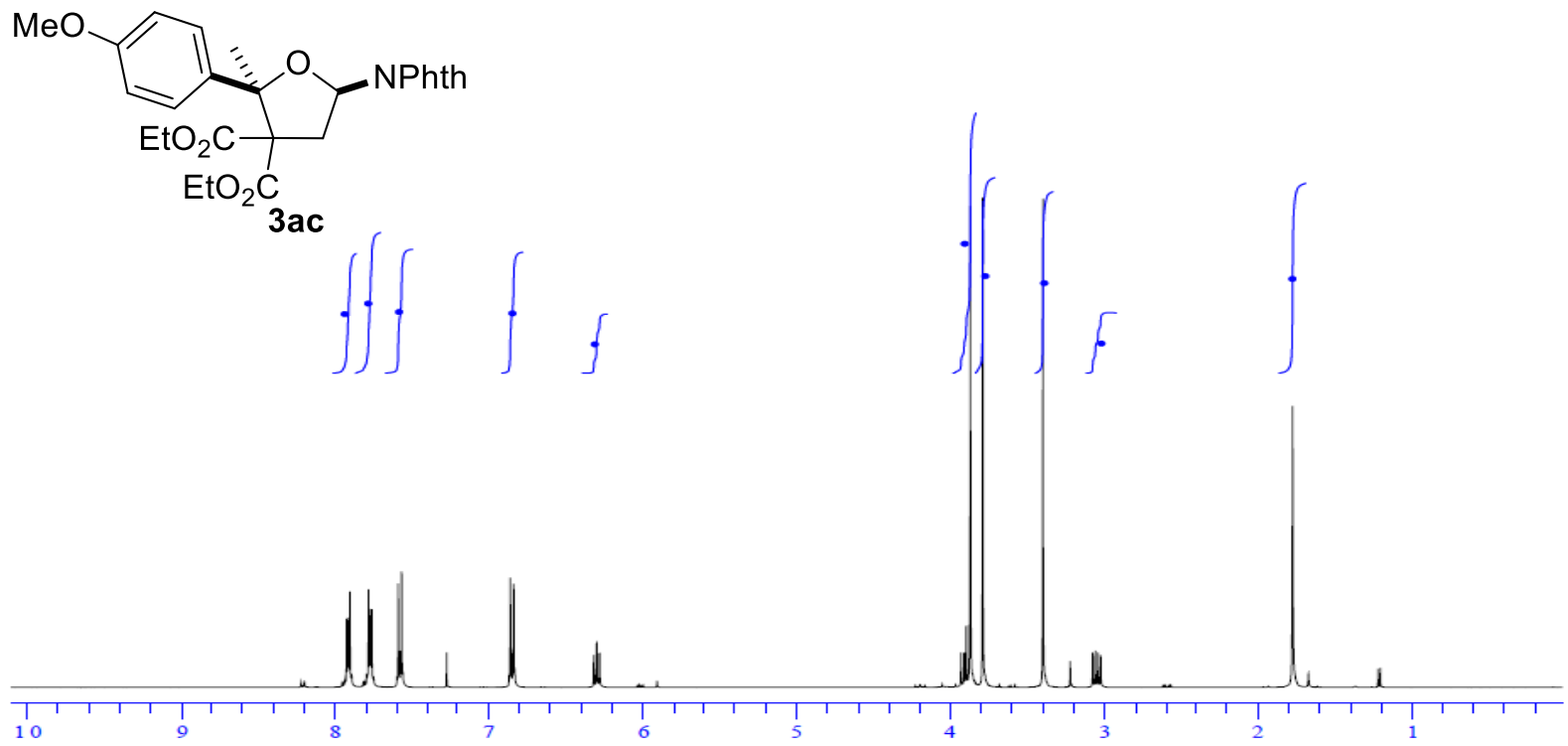

solvent: $<\mathrm{CDCI} 3>$

Frequency: 100.612769MHz
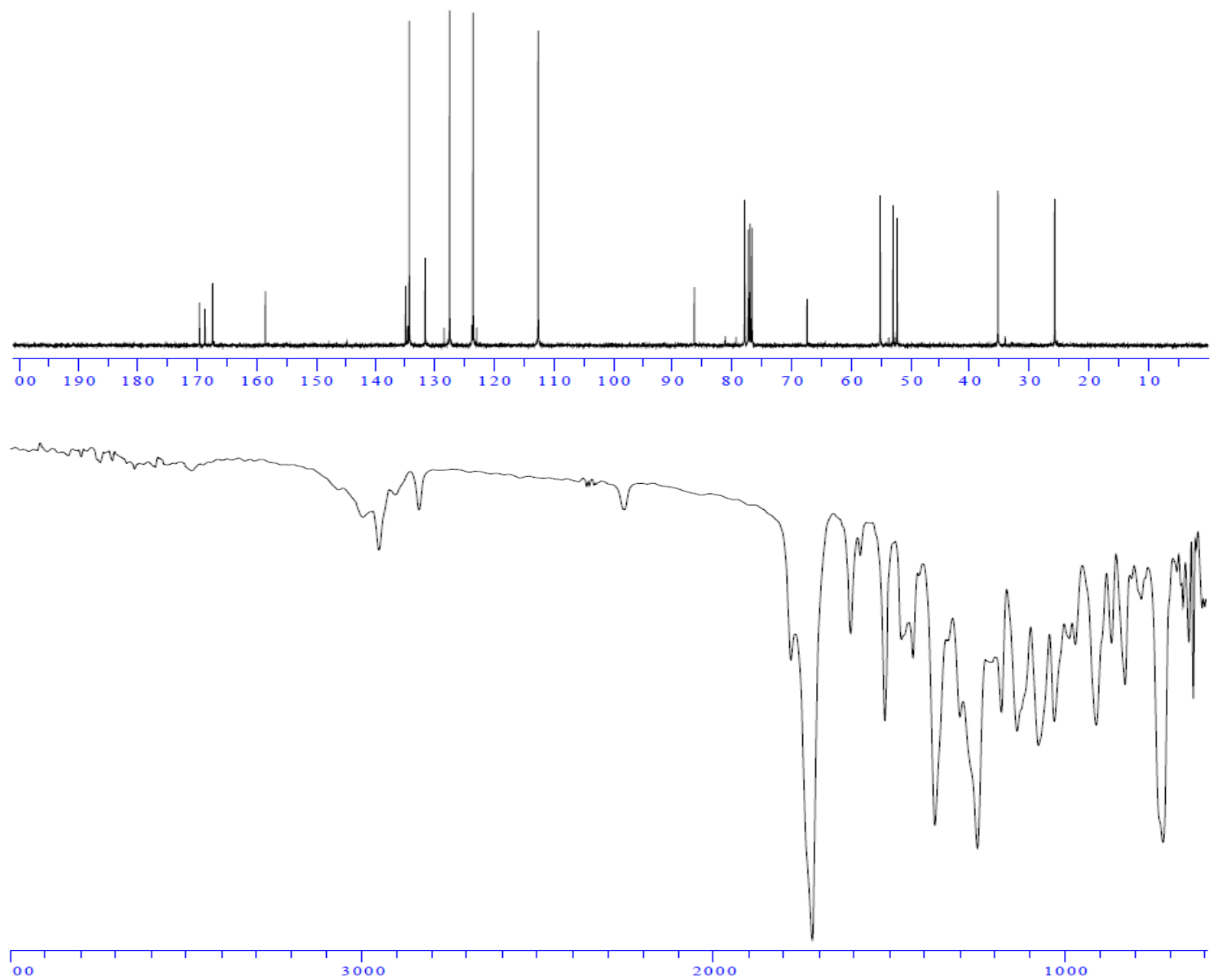
solvent: $<\mathrm{CDCl} 3>$

Frequency $400.13 \mathrm{MHz}$
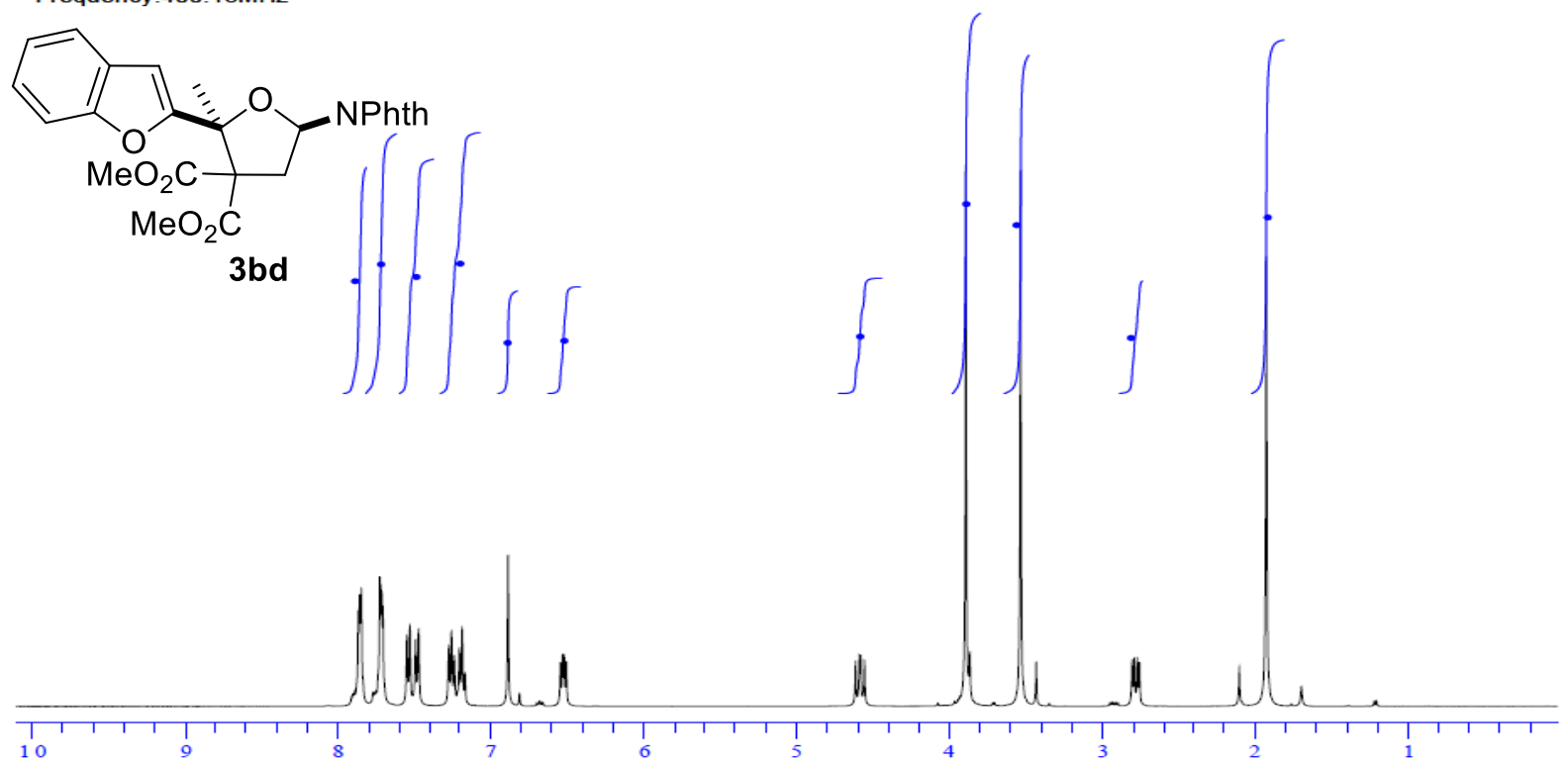

solvent: $<\mathrm{CDCl} 3>$
Frequency:100.612769MHz
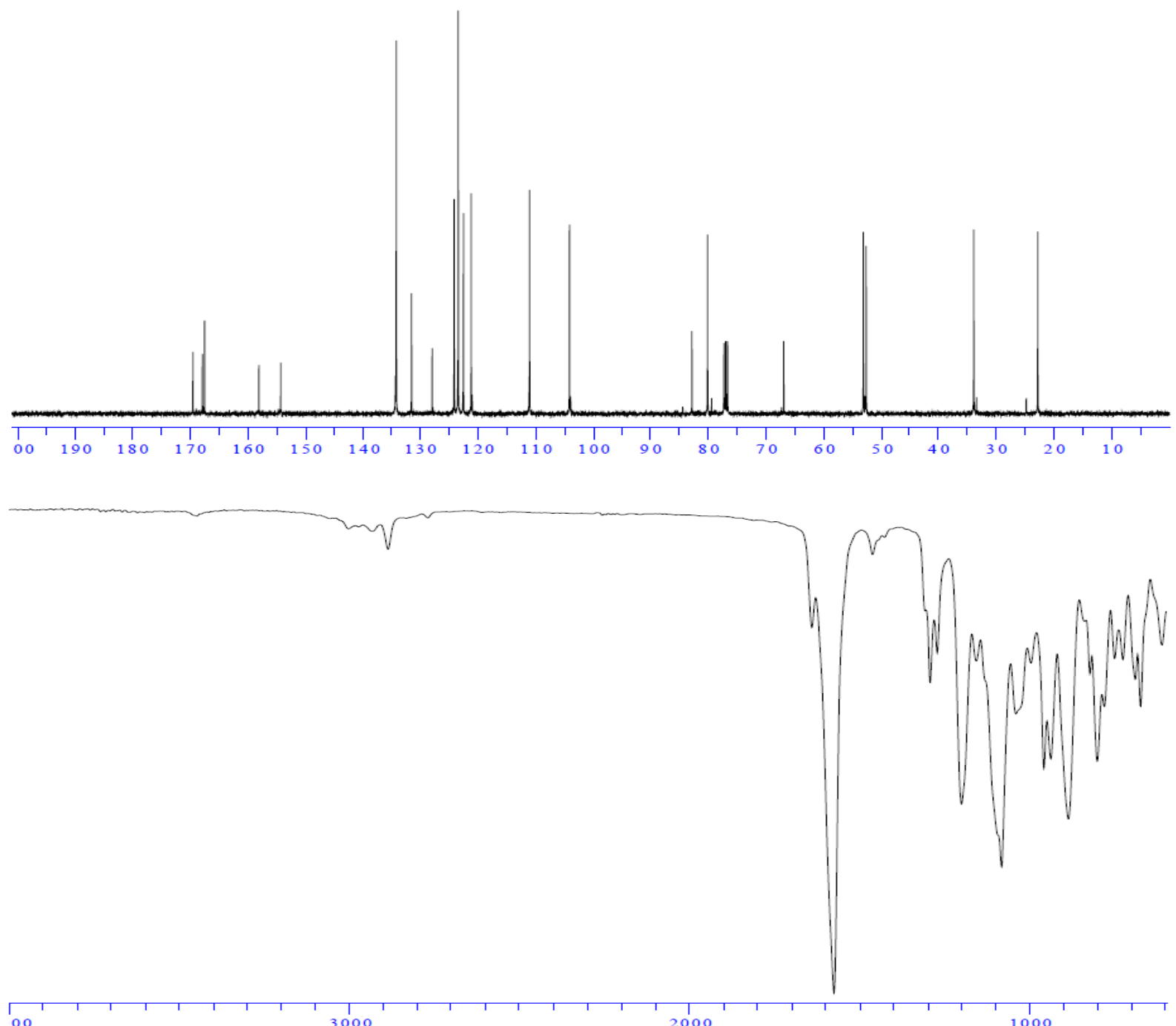
Solvent:<CDCI3>

(13MHz
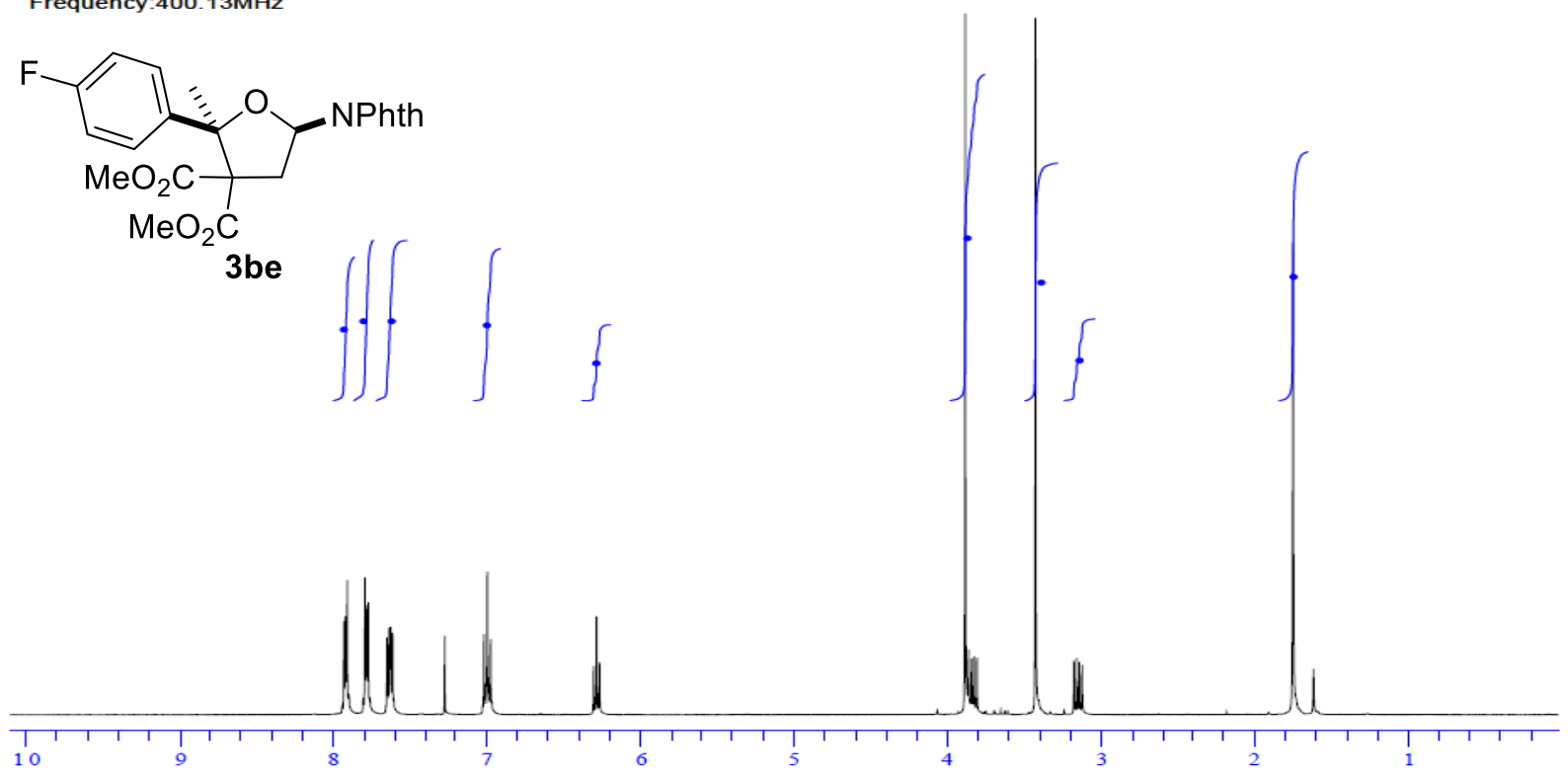

solvent: $<\mathrm{CDCI} 3>$

Frequency: $100.612769 \mathrm{MHz}$
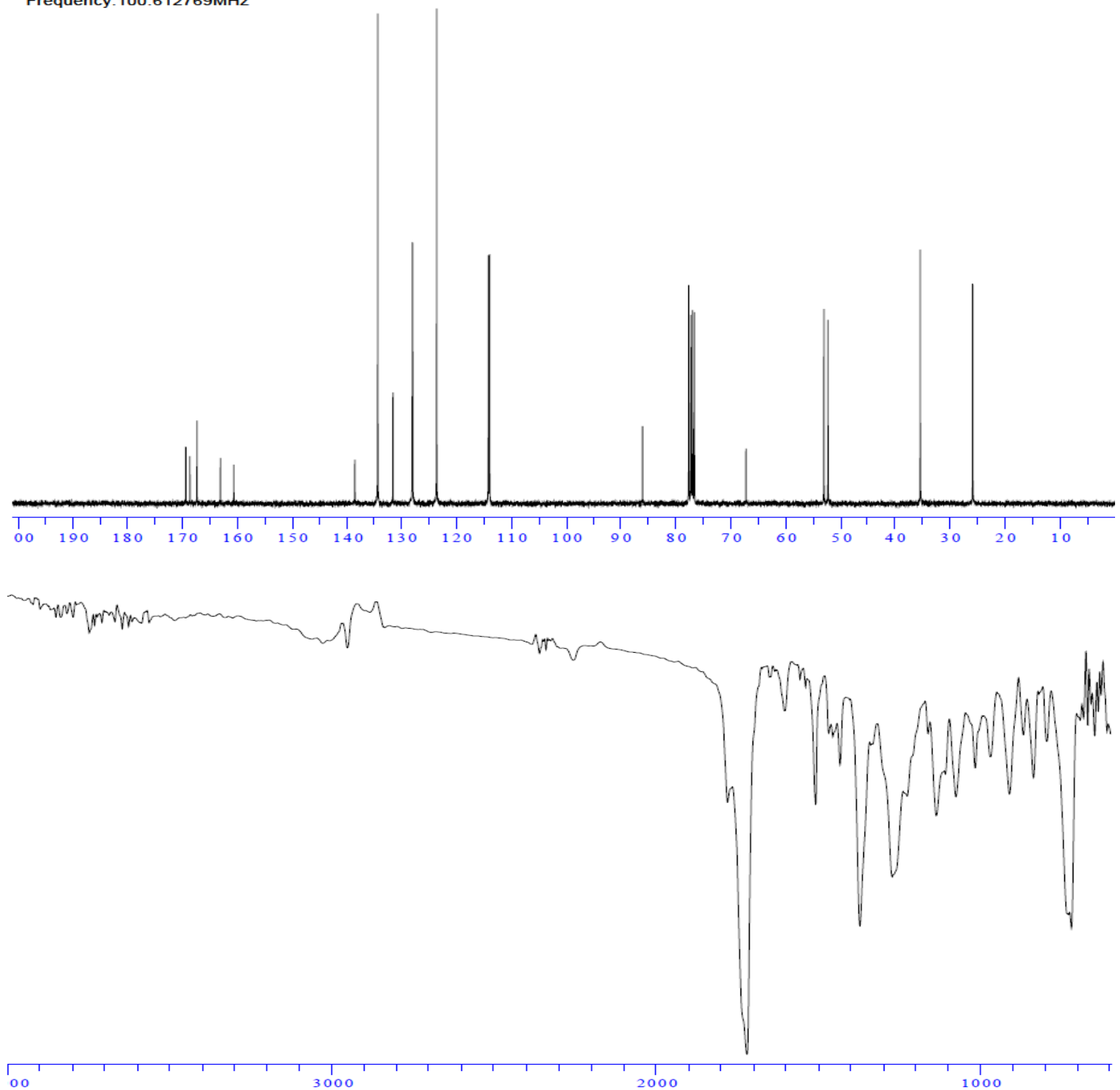
solvent: $<\mathrm{CDCI} 3>$

Frequency:400.13MHz

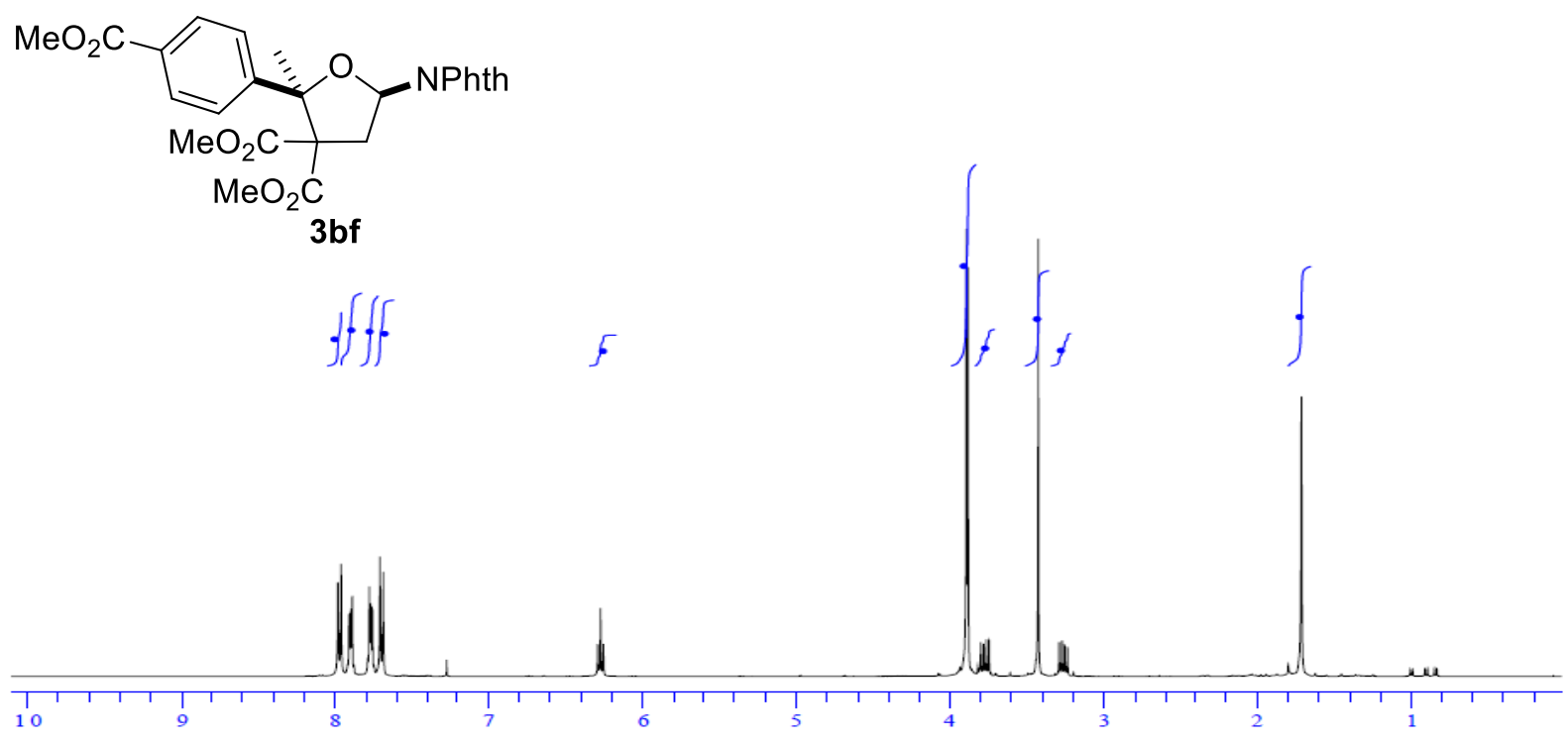

solvent:<CDCI3>

Frequency: $100.612769 \mathrm{MHz}$
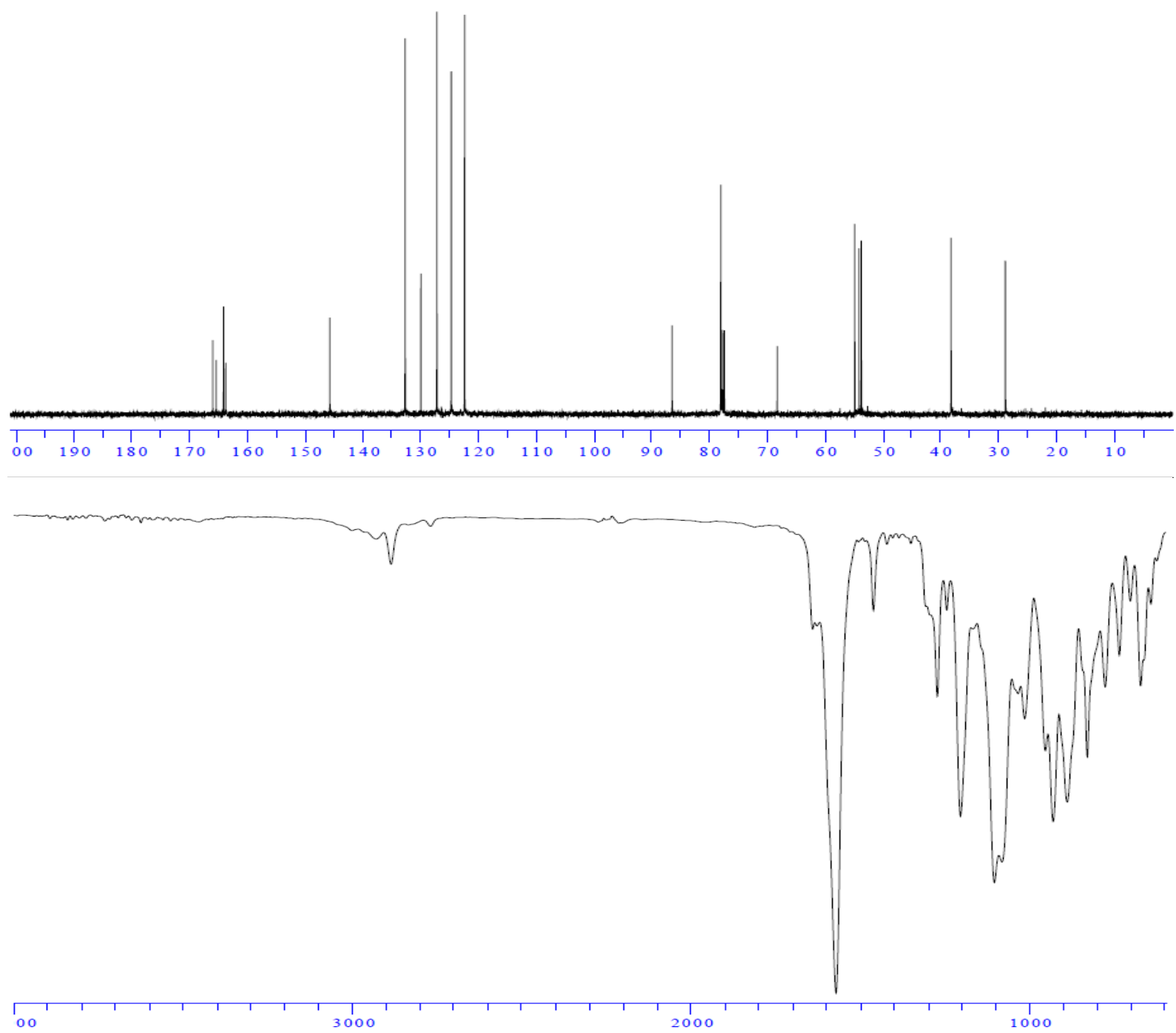
solvent:<CDCI3>

Frequency:400.13MHz

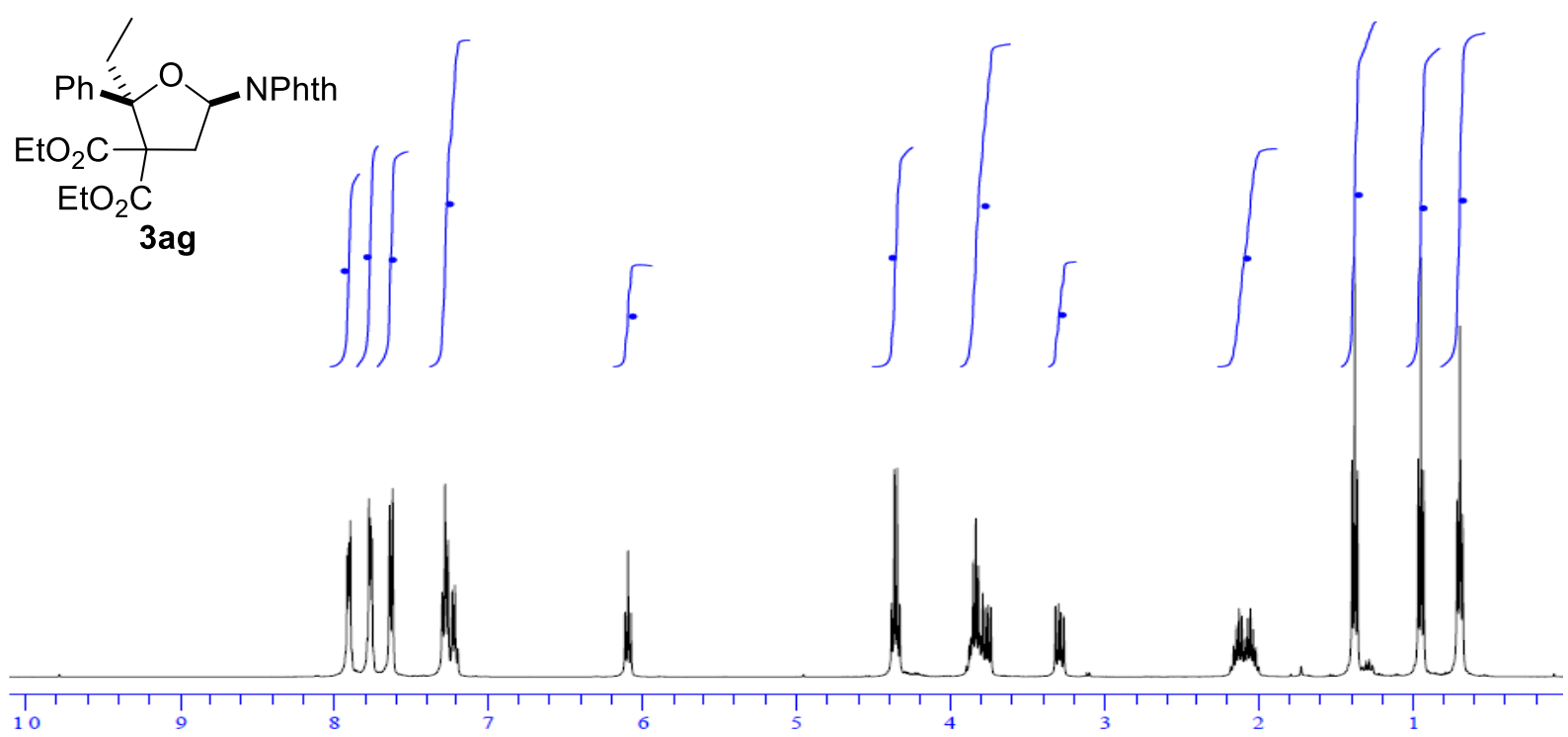

Solvent:<CDCI3>

Frequency: $100.612769 \mathrm{MHz}$
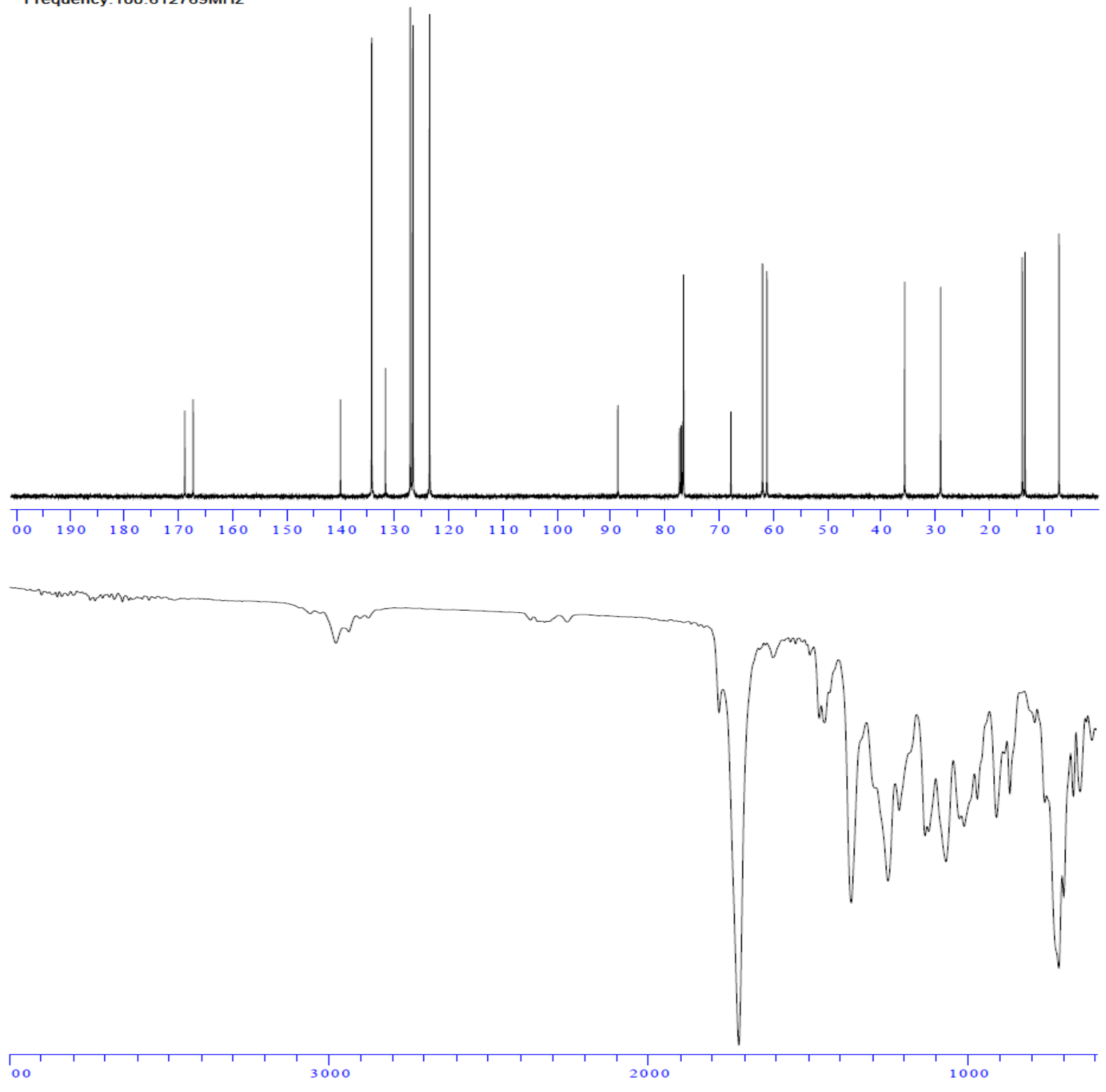
solvent:<CDCI3>

Frequency:400.13MHz
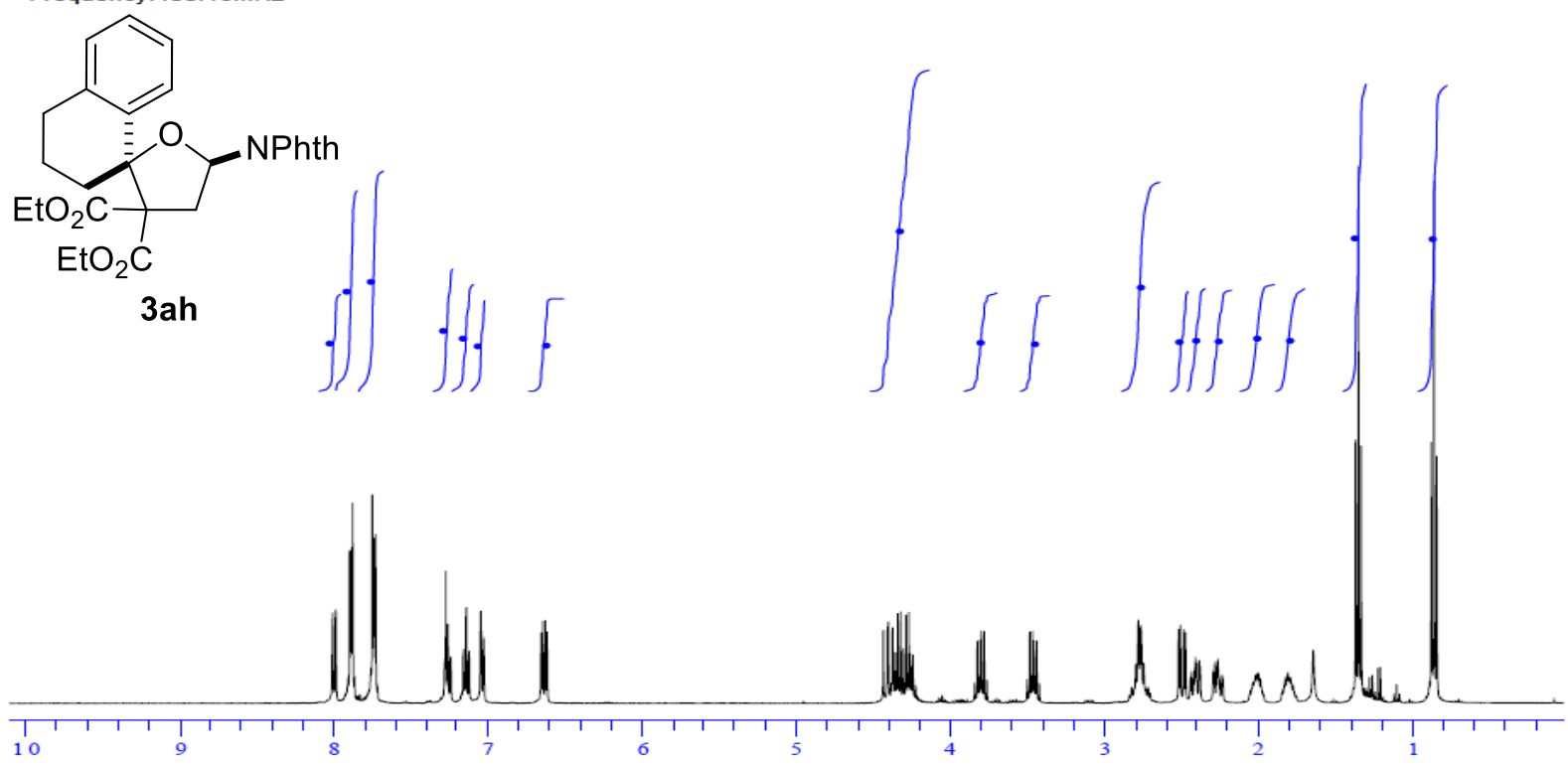

solvent: <CDCI3>

Frequency: $100.612769 \mathrm{MHz}$
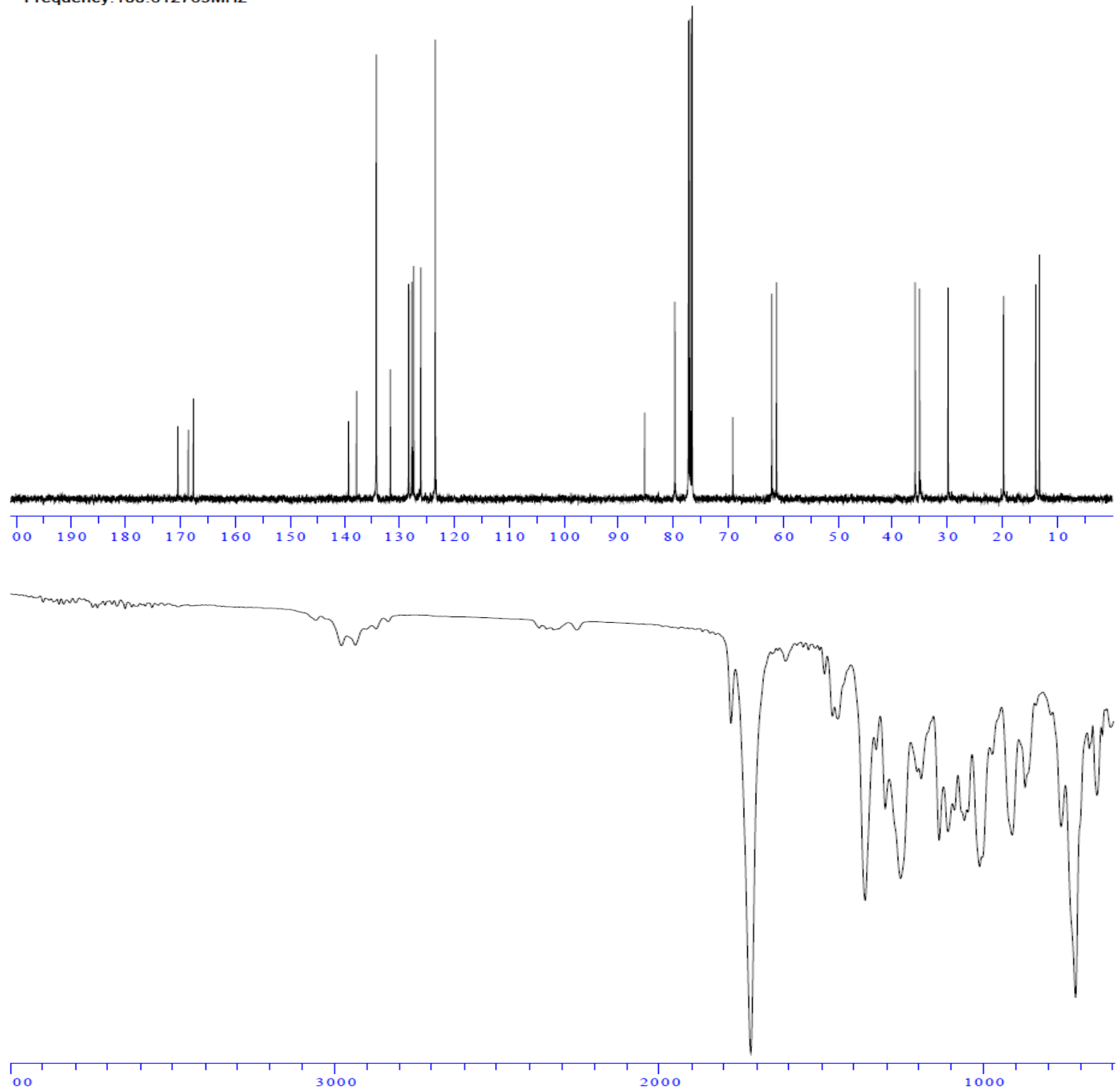
solvent: <CDCI3>

Frequency:400.13MHz
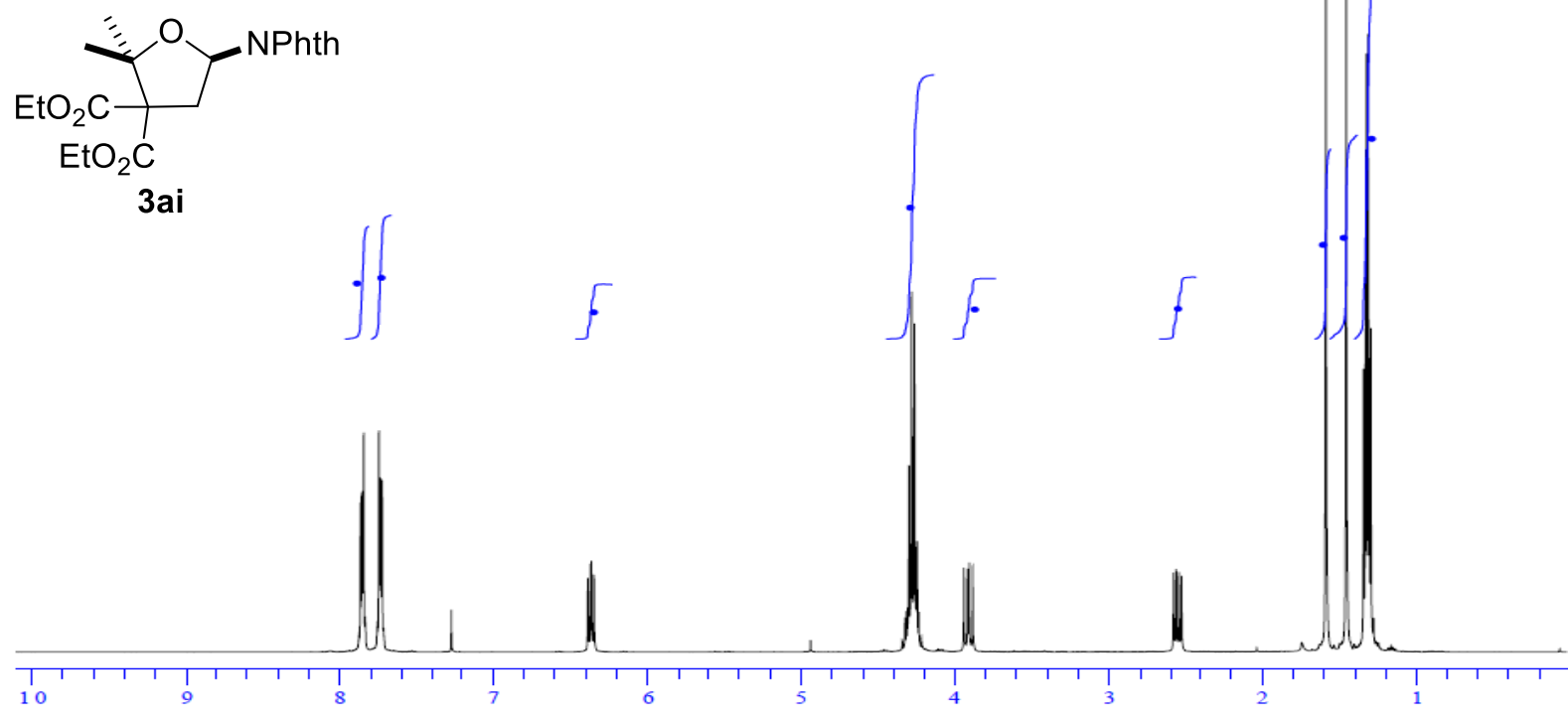

solvent: $<\mathrm{CDCI} 3>$

Frequency: $100.612769 \mathrm{MHz}$
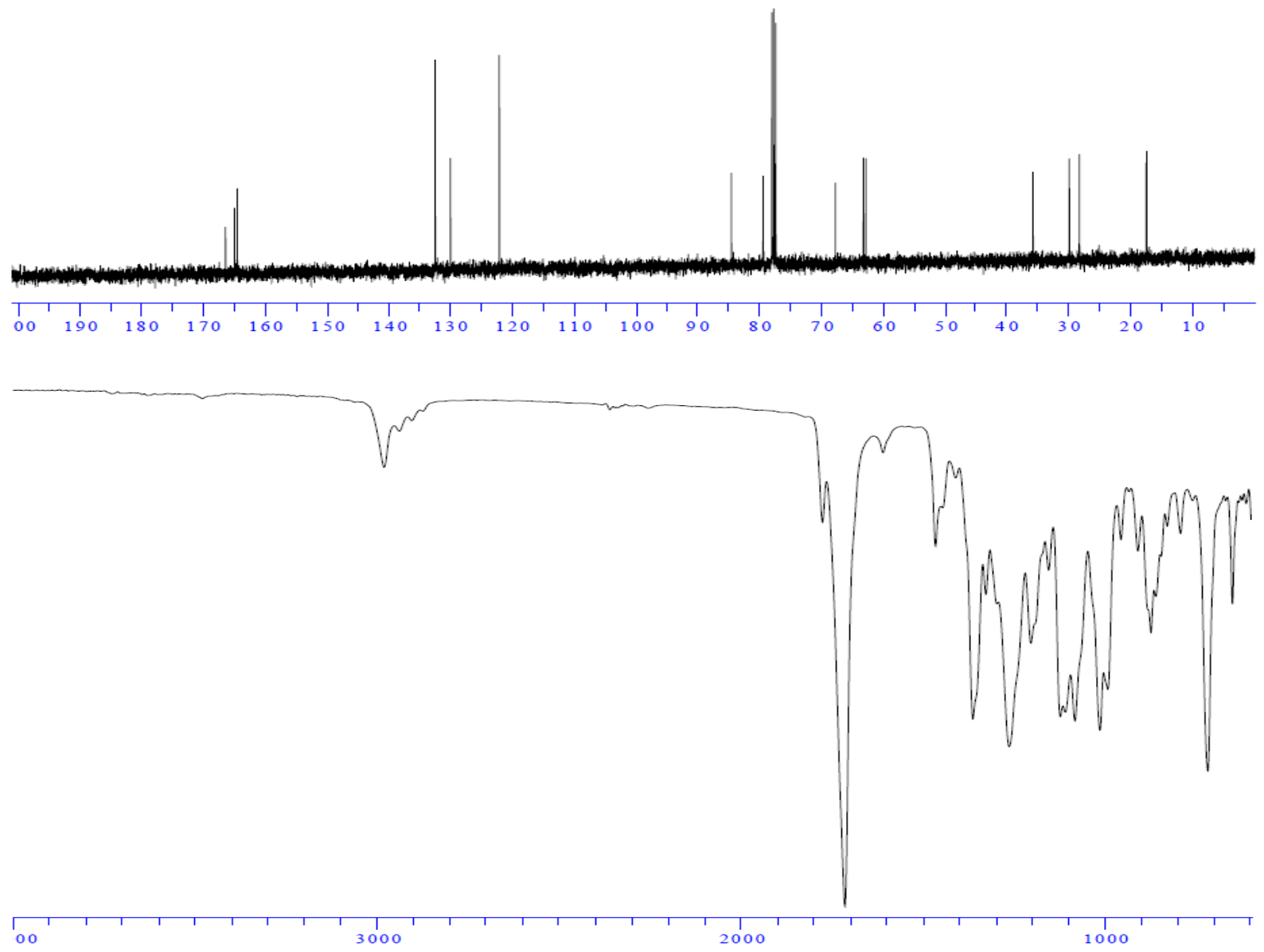
solvent: $<\mathrm{CDCl} 3>$

Frequency:400.13MHz

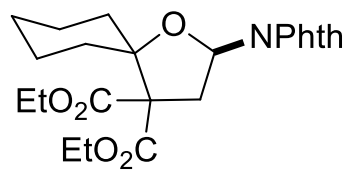

3aj

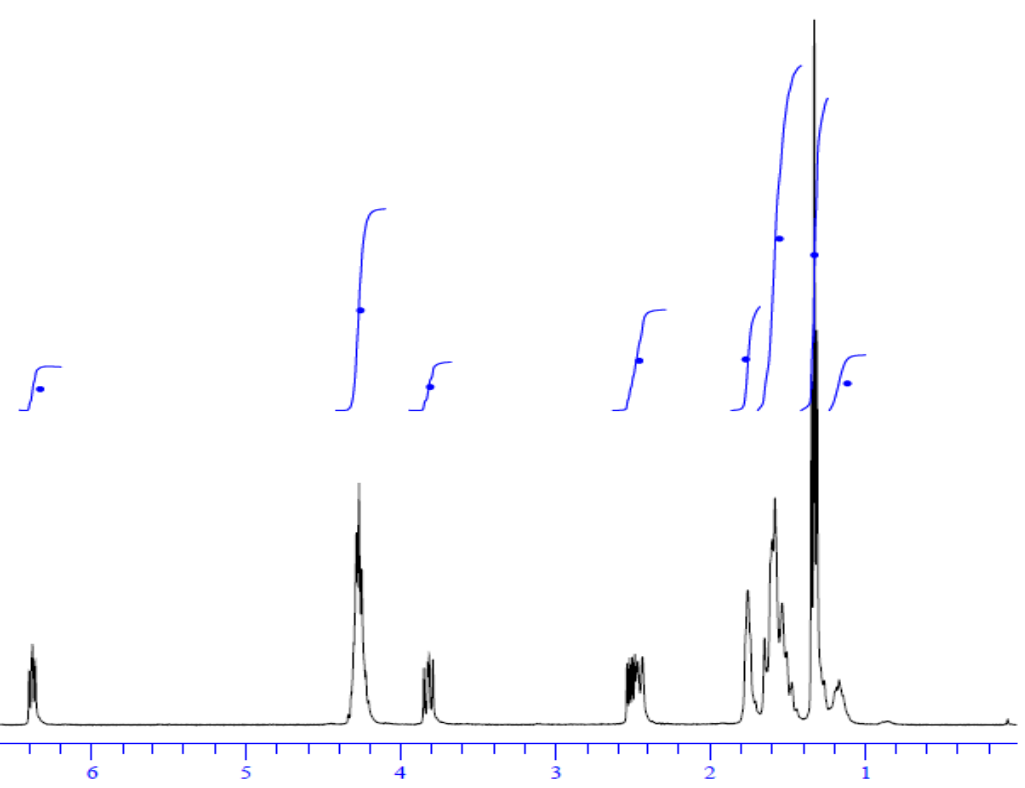

solvent:<CDCI3>

Frequency: 100.612769MHz
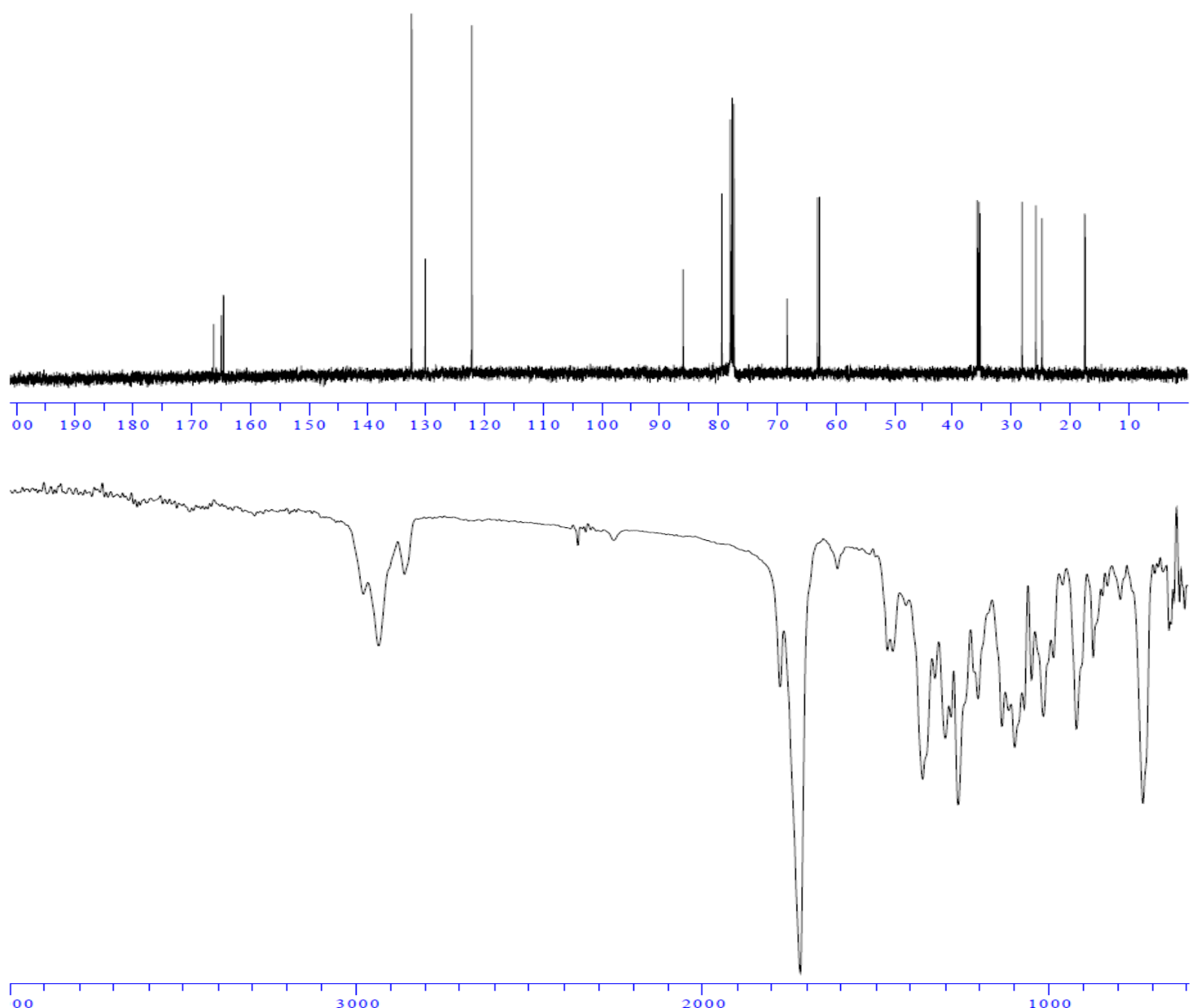
solvent:<CDCI3>

Frequency:400.13MHz

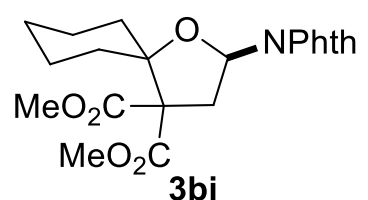

3bj

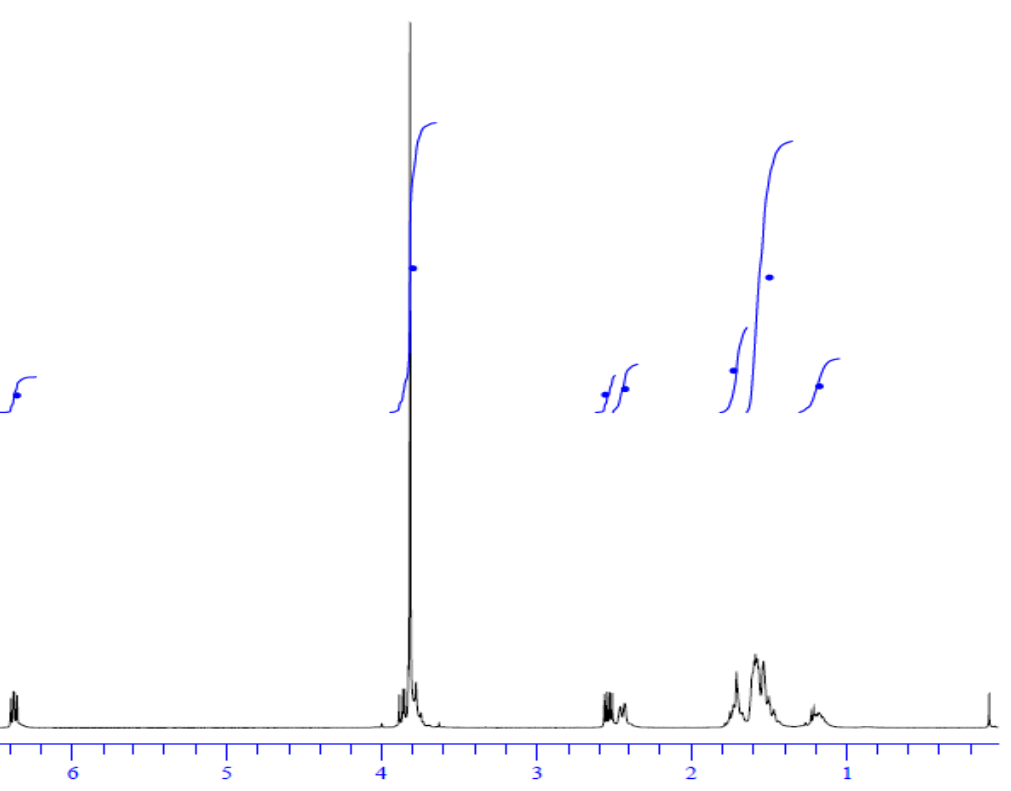

solvent: $<\mathrm{CDCI} 3>$

Frequency: $100.612769 \mathrm{MHz}$
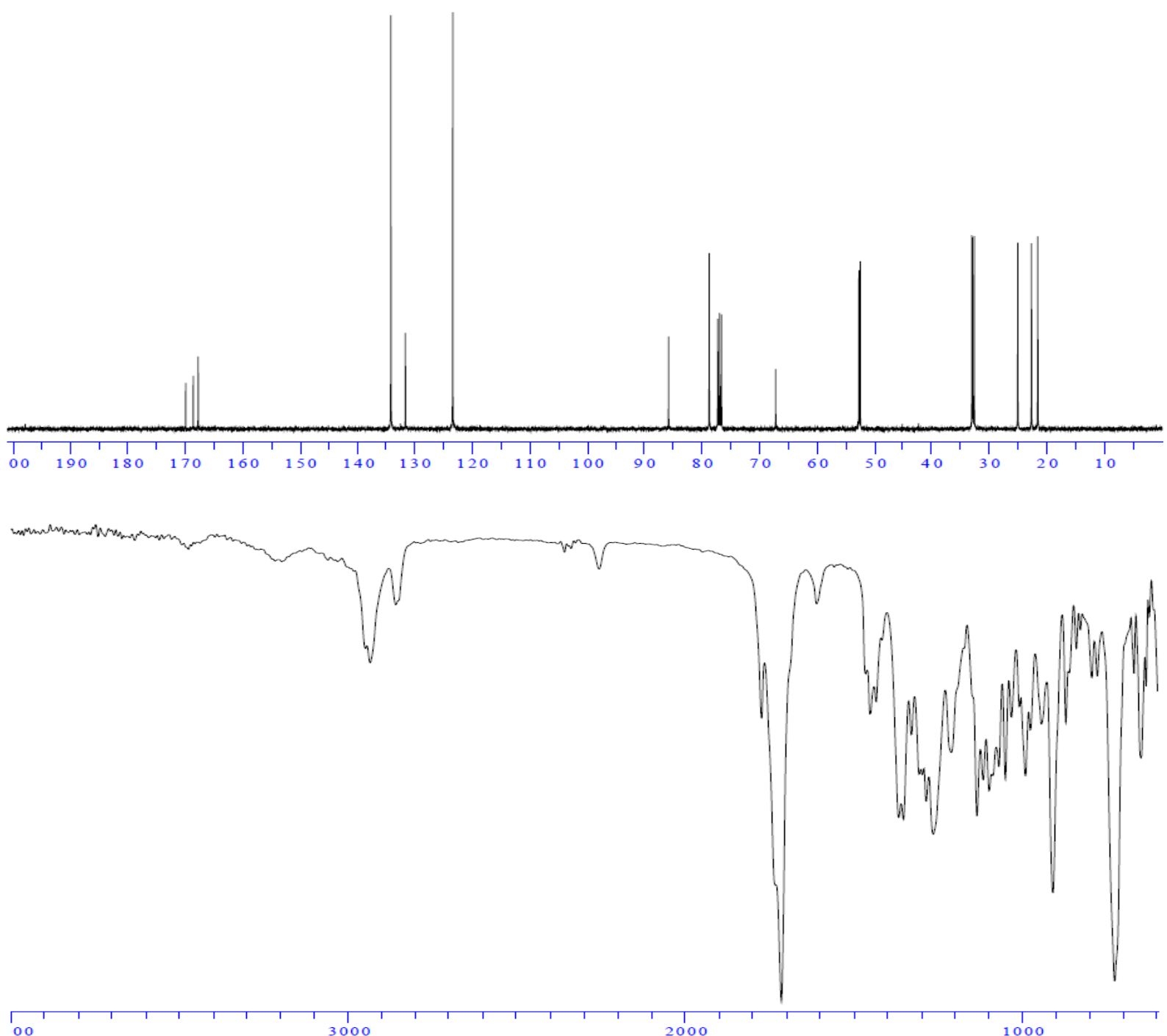
solvent: $<\mathrm{CDCl} 3>$

Frequency:400.13MHz

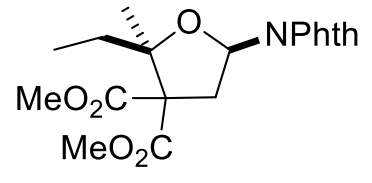

3bk

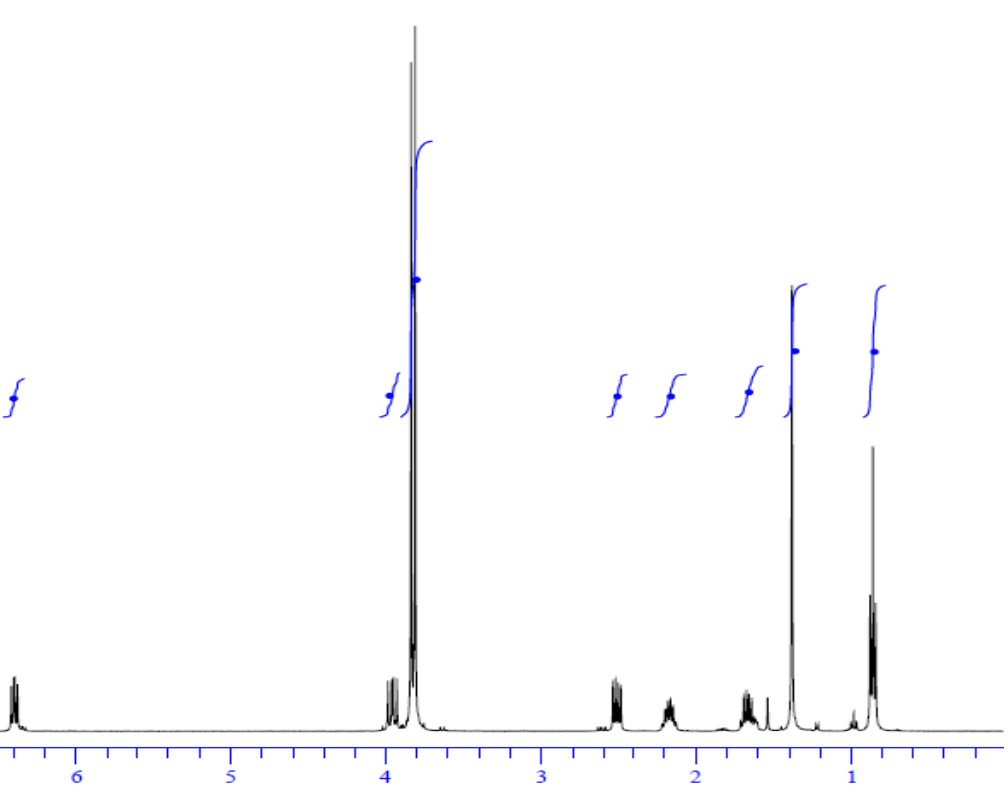

solvent:<CDCI3>

Frequency: 100.612769MHz
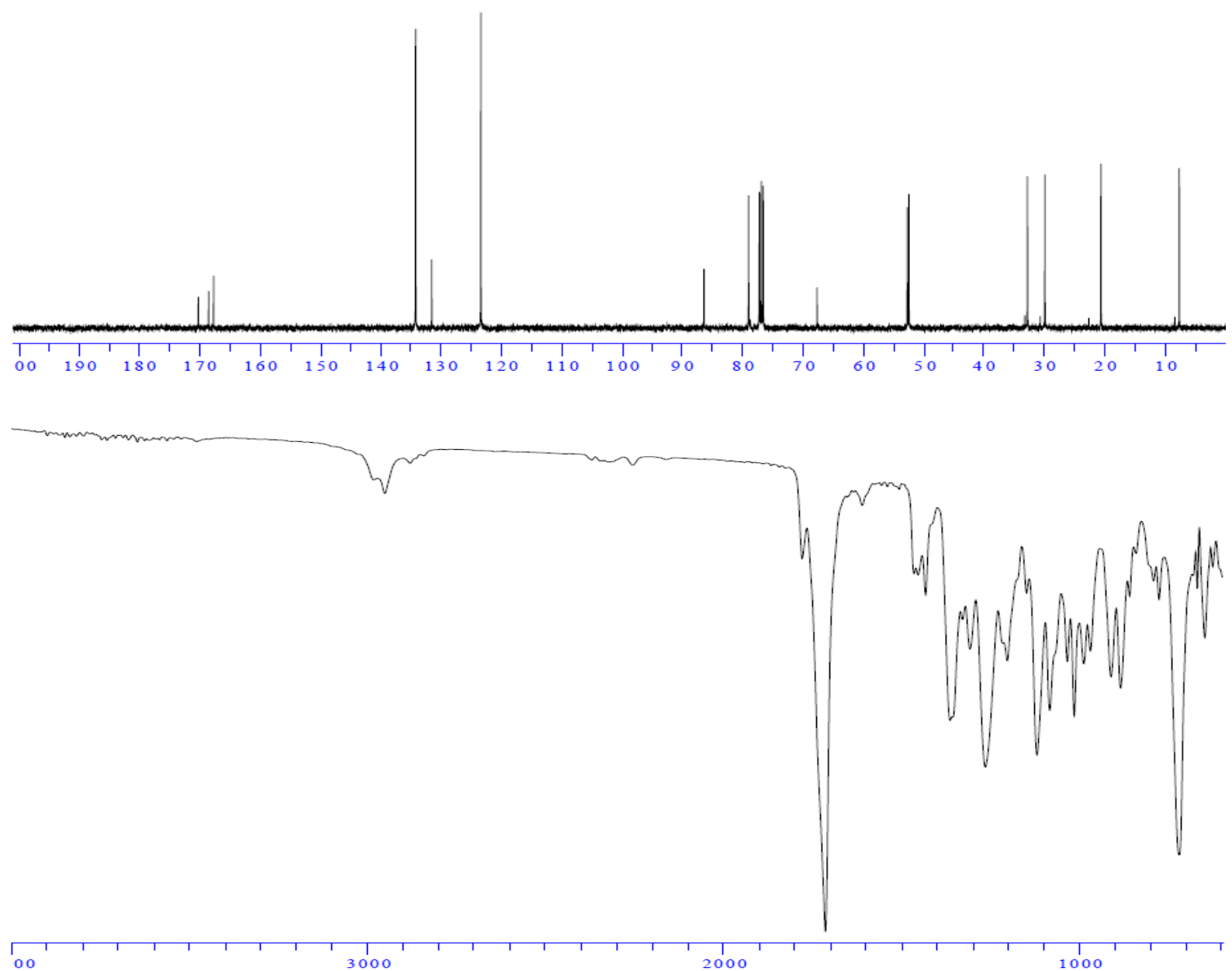

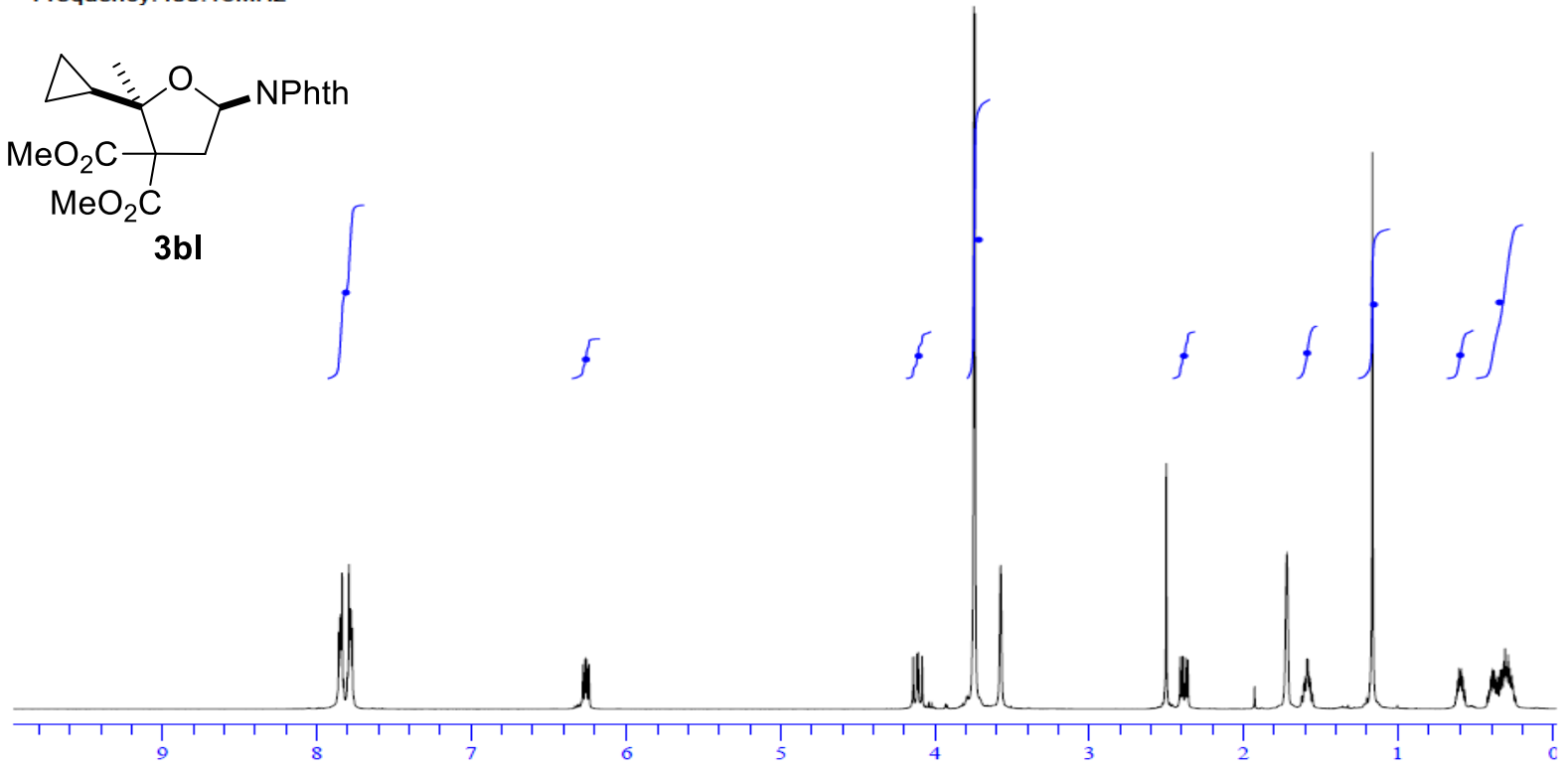

solvent:THF-d8

Frequency: 100.61

$2769 \mathrm{MHz}$

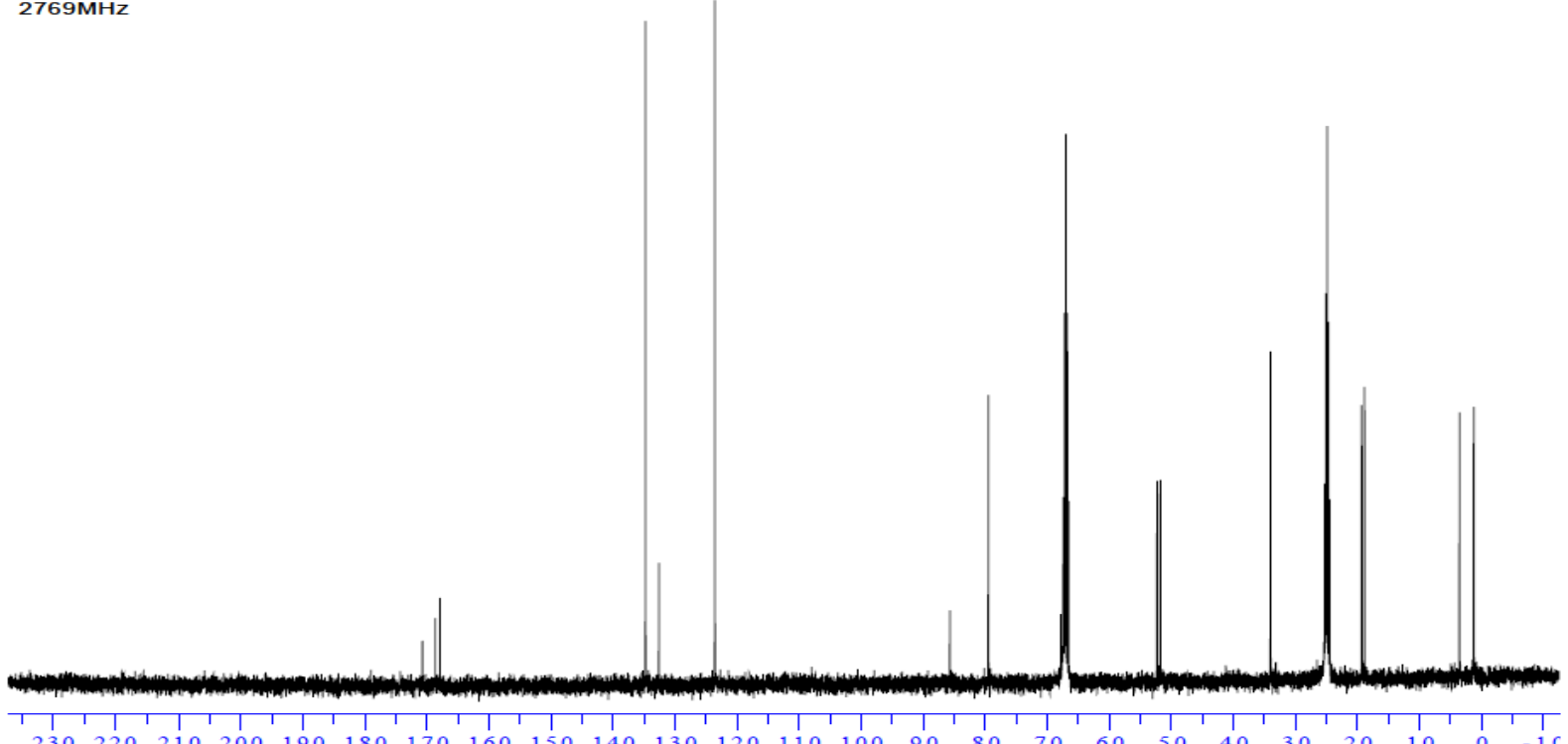

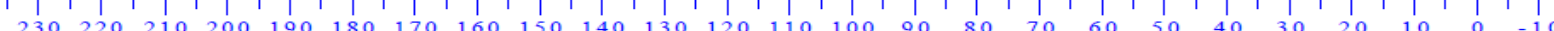

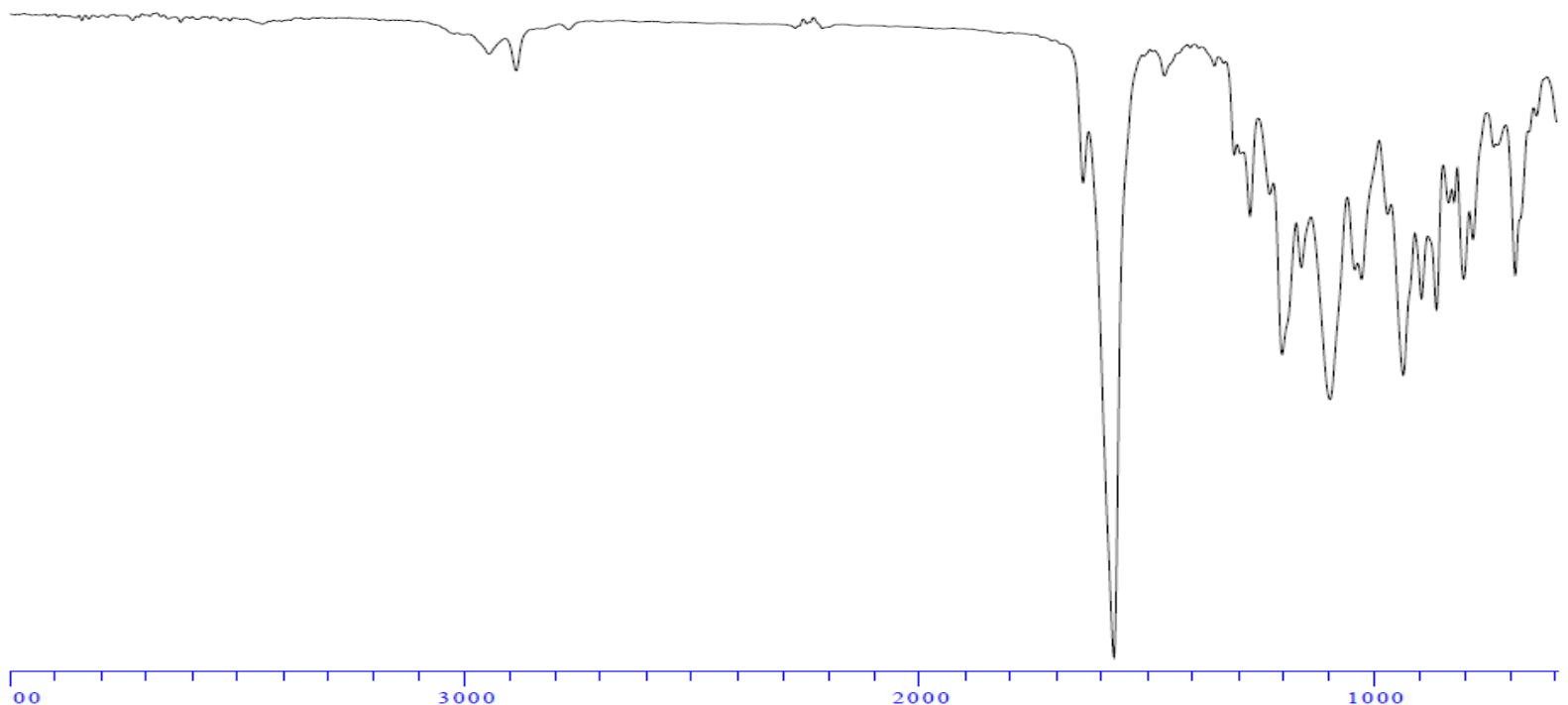


solvent:<CDCI3>

Frequency:400 $13 \mathrm{MHz}$<smiles>CCOC[C@]12C[C@@H](NPc3ccccc3)OC(C(C)C)[C@@H]1CC[C@H](C)CC2C</smiles>

$3 \mathrm{am}$

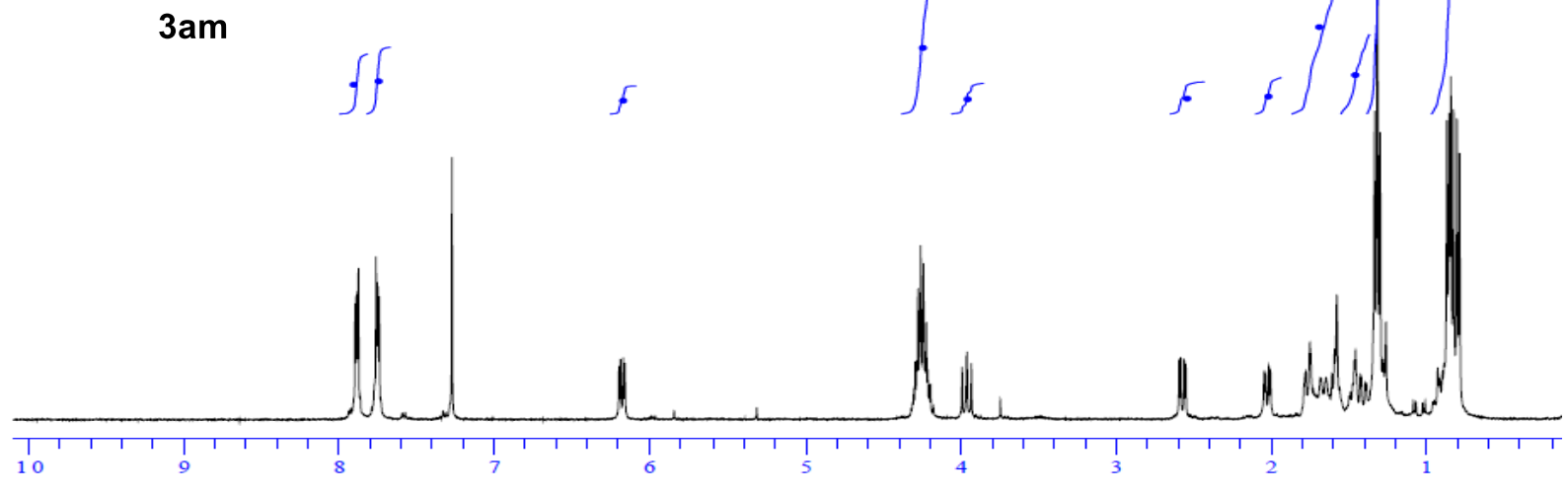

solvent: $<\mathrm{CDCI} 3>$

Frequency: 100.612769MHz
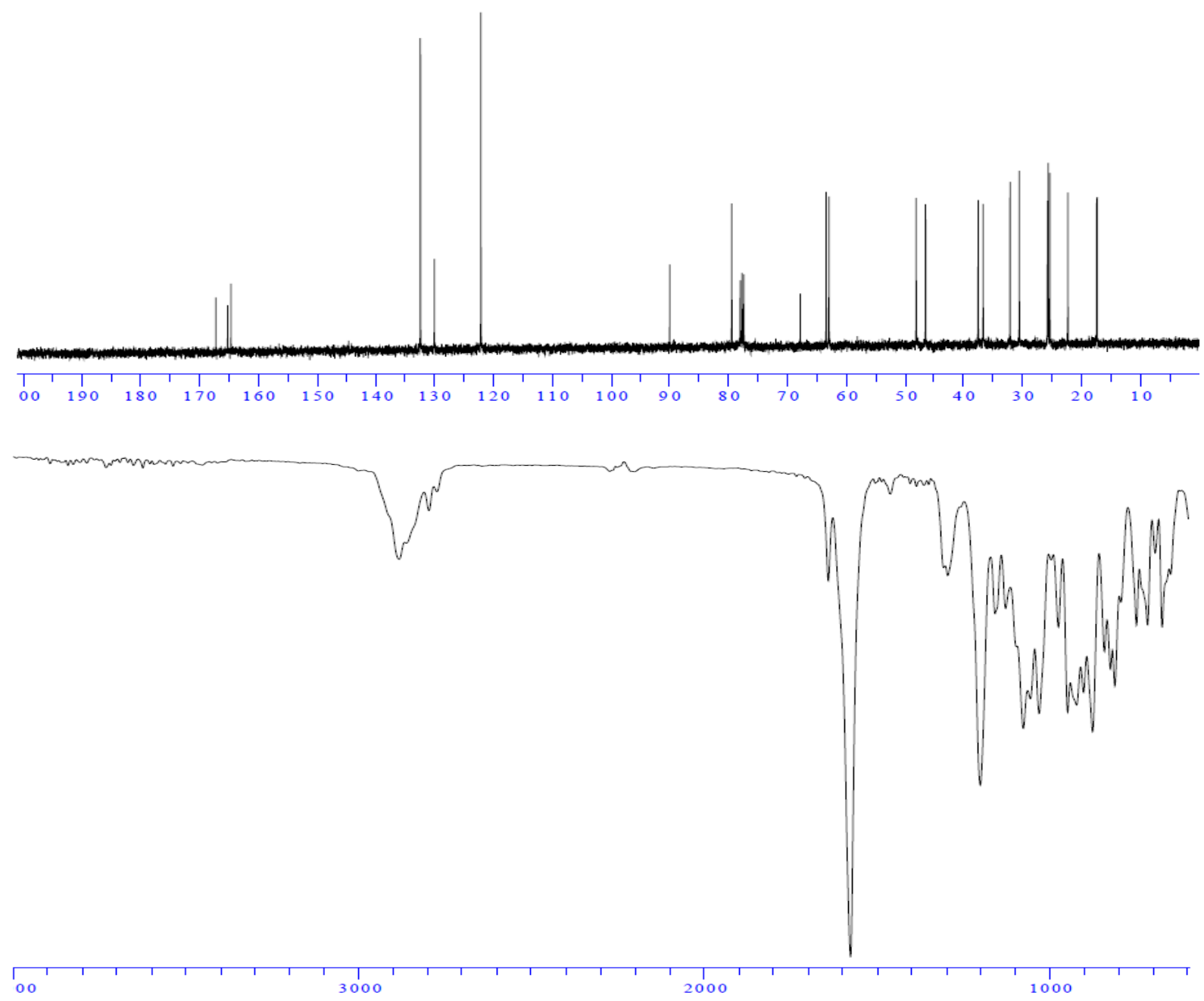


\section{Crystallographic data}

Compound 3aa was crystallized from $i \mathrm{PrOH}$.

The crystal structure of 3aa (image below) has been deposited at the Cambridge Crystallographic Data Centre and allocated the deposition number : CCDC 858768.

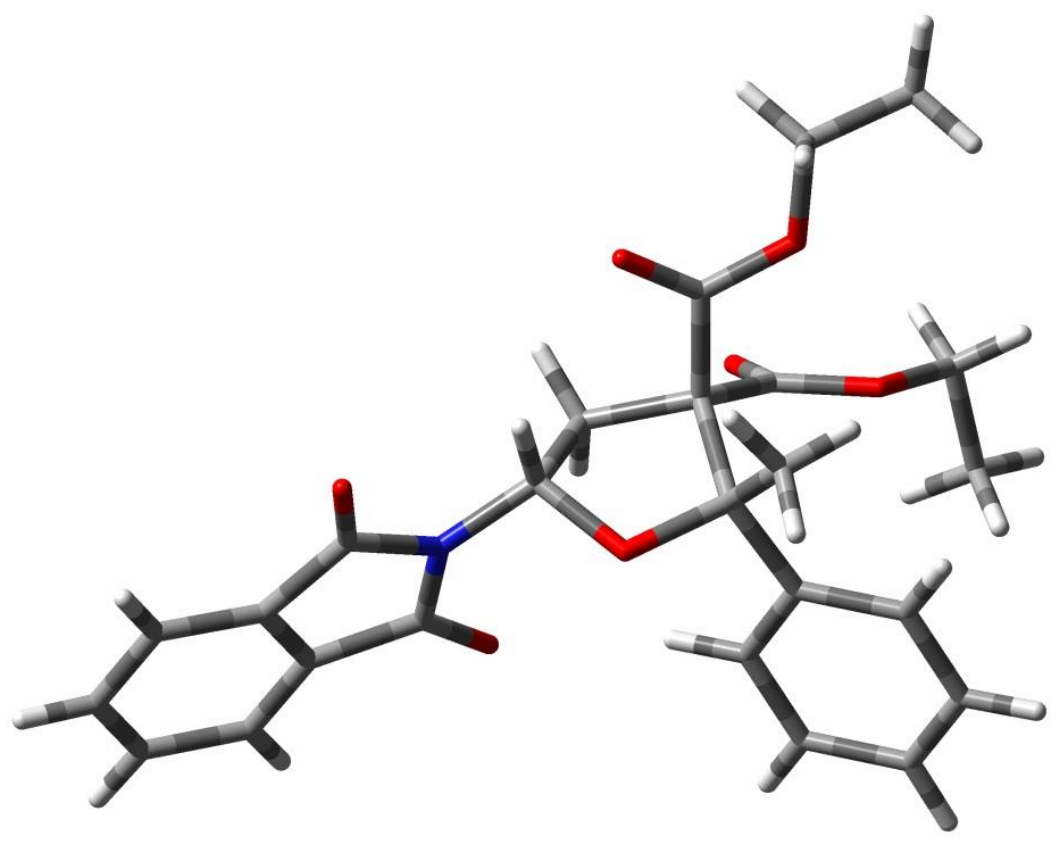

Compound epi-3aa was crystallized from $i \mathrm{PrOH}$.

The crystal structure of epi-3aa (image below) has been deposited at the Cambridge Crystallographic Data Centre and allocated the deposition number : CCDC 858769.

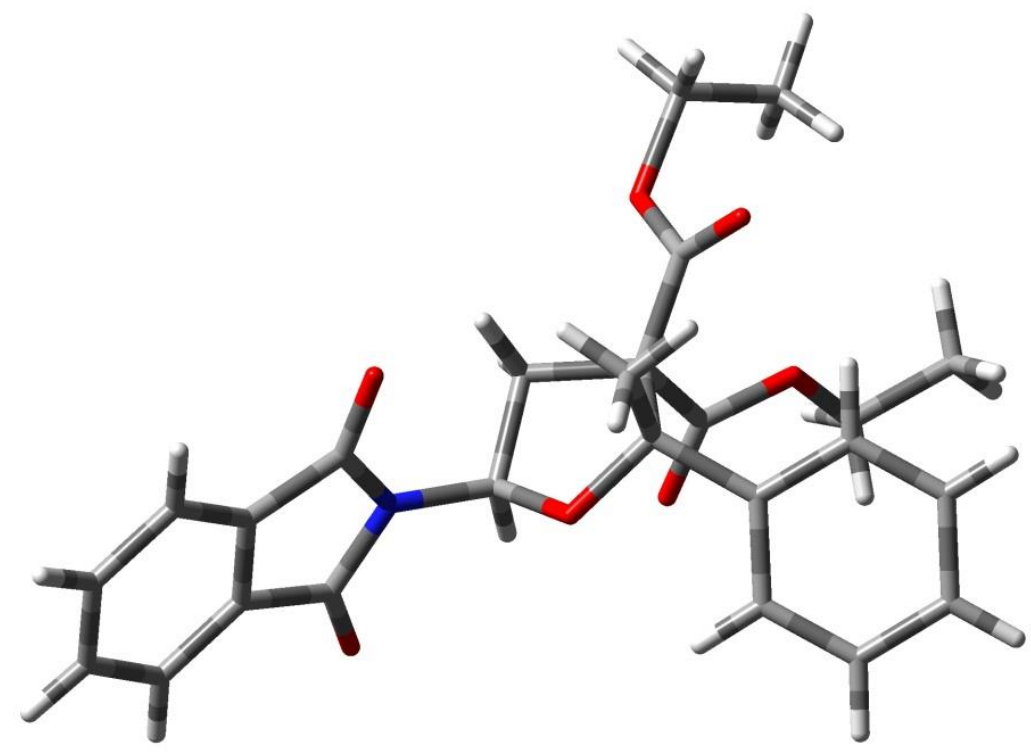


Compound 3am was crystallized from $n$-hexane.

The crystal structure of 3am (image below) has been deposited at the Cambridge Crystallographic Data Centre and allocated the deposition number : CCDC 861951.

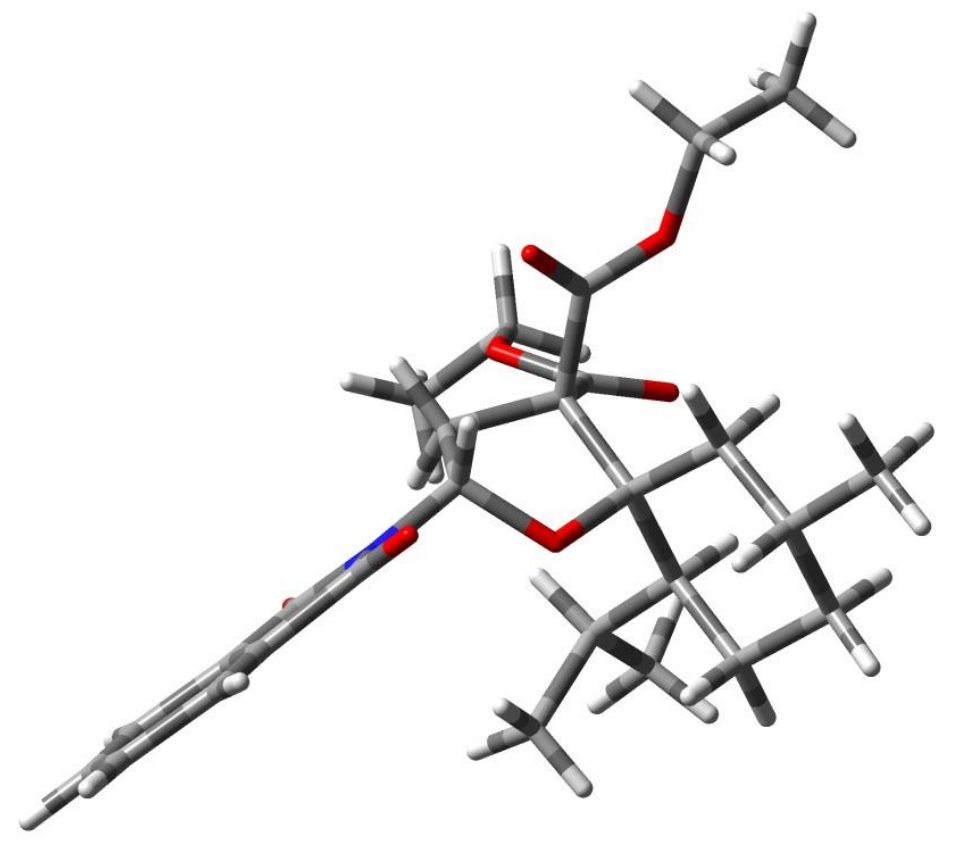

